UNIVERSIDADE DE BRASÍLIA

INSTITUTO DE PSICOLOGIA

PROGRAMA DE PÓS-GRADUAÇÃO EM PSICOLOGIA CLÍNICA E CULTURA TESE DE DOUTORADO

\title{
A IDENTIFICAÇÃO E O NARCISISMO NA MELANCOLIA- REFLEXÕES A PARTIR DA OBRA FREUDIANA
}

Renata Leite Soares 
RENATA LEITE SOARES

\section{A IDENTIFICAÇÃO E O NARCISISMO NA MELANCOLIA- REFLEXÕES A PARTIR DA OBRA FREUDIANA}

Tese apresentada ao Programa de Pós-
graduação em Psicologia Clínica e Cultura da
Universidade de Brasília como requisito à
obtenção do título de Doutora em Psicologia.

Orientador: Prof. ${ }^{\circ}$ Dr. Luiz Augusto M. Celes

Brasília 


\section{A IDENTIFICAÇÃO E O NARCISISMO NA MELANCOLIA- REFLEXÕES A PARTIR DA OBRA FREUDIANA}

Tese apresentada ao Programa de Pós-graduação em Psicologia clínica e cultura da Universidade de Brasília como requisito à obtenção do título de Doutora em Psicologia.

\section{Banca Examinadora:}

Presidente:

Prof. Dr. Luiz Augusto M. Celes

Universidade de Brasília - UnB

\section{Membro:}

Prof $^{\mathrm{a}}$. Dr ${ }^{\mathrm{a}}$. Anita Cristina Azevedo Resende

Universidade Federal de Goiás- UFG

Membro:

Prof $^{\mathrm{a}}$. Dra . Eliana Rigotto Lazzarini

Universidade de Brasília - UNB

Membro:

Prof $^{\mathrm{a}}$. Dra ${ }^{\mathrm{a}}$. Estela Ribeiro Versiani

Universidade de Brasília - UnB

Membro:

Prof $^{\mathrm{a}}$. Dr ${ }^{\mathrm{a}}$. Terezinha de Camargo Viana

Universidade de Brasília - UnB

\section{Suplente:}

Prof $^{\mathrm{a}}$. Dr ${ }^{\mathrm{a}}$. Dione de Medeiros Lula Zavaroni

Universidade de Brasília - UnB 


\section{AGRADECIMENTOS}

Ao Luiz Celes, meu orientador, pelos ensinamentos, rigor e discussões realizados no desenvolvimento da tese e pela disponibilidade e confiança na condução do processo.

À professora Eliana Lazarinni, pelas discussões teóricas, carinho e cuidado com que auxiliou o meu processo de formação nestes anos de realização do doutorado.

Aos professores do Programa de Pós Graduação e Pesquisa em Psicologia Clínica e Cultura, pelas leituras e discussões nas disciplinas cursadas, importantes na delimitação e desenvolvimento do problema de pesquisa.

À Faculdade de Educação da Universidade Federal de Goiás, pela licença concedida para a realização do doutorado.

À Anita que, além da contribuição fundamental na banca de qualificação, fez parte, de forma singular, de minha formação, desde o princípio. Com ela, aprendi a importância e a fertilidade de uma sólida formação teórica e os desdobramentos do conhecimento pela vida afora.

Às professoras Terezinha, Estela e Dione, pela disponibilidade em participar da banca de defesa, pela leitura do trabalho e contribuição nesta etapa de meu processo formativo.

À professora Estela, pela participação e contribuição fundamental na banca de qualificação.

À Albertina, pela revisão do texto e por fazer parte, com seus ensinamentos, rigor, generosidade e delicadeza, da minha formação.

Ao Lucas, meu filho, por todo o amor e jeito, doce e simples, com quem aprendo diariamente sobre a vida, o tempo e as palavras.

À Paula, amiga e vizinha, com quem pude compartilhar, em Brasília, em tempos de tantas descobertas e de escrita, os dilemas da tese e da vida, "absurdando a vida de leste a oeste"! À Veri, irmã de vida, pela casa e o aconchego, desde sempre e especialmente nos tempos de morada no planalto central.

À minha mãe, Maria Amélia, por deixar em mim o gosto pelas coisas que a gente não entende, mas sente, e por todo o amor, carinho, apoio, compreensão e disponibilidade nos momentos de realização deste trabalho e na vida.

Ao Valter querido, pelo carinho, respeito, presença e apoio constantes e definitivos em todas as minhas escolhas.

Ao meu pai, pela força, determinação e encantamento com que encara a vida desde sempre.

Às minhas irmãs, Flávia, Ligia e Julia, pela parceria e amor tão presentes apesar da distância. 


\section{RESUMO}

Esta tese investiga a ligação entre o narcisismo e a identificação na melancolia. A teoria freudiana dispõe a melancolia como uma afecção psíquica que se encontra no limiar entre a neurose e a psicose na relação existente entre o Eu e a realidade. Enquanto neurose narcísica, a melancolia evidencia a dificuldade do melancólico de desvincular-se de um objeto perdido, o que o impede de canalizar a libido para novos investimentos. $\mathrm{O}$ desdobramento dessa relação é uma convergência entre o amor e o ódio ocasionada pela identificação do Eu ao objeto perdido. Os riscos dessa convergência é que, permanecendo a libido ligada ao Eu na iminência de preservar a identificação ao objeto, o ódio não encontra, através da libido, meio de canalização para o mundo externo. Vivendo sob a sombra de um objeto perdido, o Eu refugia-se da perda do amor e divide-se para defender-se do ódio que a ele retorna com o objeto, resultando na formação de uma rígida consciência moral que se expressa sob a forma do Supereu. Na origem da afecção melancólica, encontra-se uma escolha objetal narcisista e uma identificação a um objeto de amor que não pode ser abandonado. O trabalho se realiza pela pesquisa bibliográfica fundamentada, sobretudo, na obra freudiana. Busca, inicialmente, compreender a importância do narcisismo como tempo inicial de constituição do Eu e sua vinculação à teoria das pulsões e à compreensão da natureza do objeto para a psicanálise. Em seguida, caracterizando o complexo de Édipo em sua vinculação com a castração, problematiza a constituição do Supereu e a importância dessa vinculação na identificação e nos destinos libidinais que caracterizam diferentes afecções psíquicas. Por fim, a melancolia é caracterizada e problematizada a partir dessas relações. Apreendê-la no limiar entre a neurose e a psicose, tal qual caracterizada por Freud, revelou-se uma forma de recolocar a questão do conflito entre a realidade e o sujeito, que, a par de revelar-se obscurecido e amortecido, embora atuante, permanece expressando as possibilidades de Eros em sua relação com a pulsão de morte.

Palavras-chave: identificação, narcisismo, melancolia, objeto 


\begin{abstract}
This thesis investigates the relationship between narcissism and the identification in melancholy, basing itself in Freud's work. Freud's theory considers melancholy as a psychic condition which finds itself as a tenuous border between neurosis and psychosis within the relationship between ego and reality. As a narcissistic neurosis, melancholy shows the difficulties of a melancholic in withdrawing from the lost object, which prevents the person from channeling the libido to new investments. The unfolding of this relationship is a convergence between love and hate that happens due to the identification the ego finds in the lost object. The risks of such convergence is that, being the libido connected to the ego in an attempt to preserve the identification of the object, hate does not find, through libido, means of being channeled to the outside world. Living in the shadow of a lost object, the ego finds refugee on itself in order to preserve love. The ego, then, divides itself to defend love from hate. The latter returns with the object, forming a rigid moral conscience expressed as Superego. A narcissistic object choice and an identification of an object of love that cannot be abandoned are found in the origins of melancholic condition. The work is done by literature based mainly on Freud's work. It aims, initially, at comprehending the importance of narcissism as the initial formation of Ego and its link to the theory of instinct and to the comprehension of the object's nature to psychoanalysis. Next, characterizing the Oedipus complex and its ties with castration, this work problematizes the constitution of Superego and the importance of such ties on the identification and on the libidinal destinations that characterize different psychic conditions. Finally, melancholy is problematized within the intertwining of narcissism and identification. The comprehension of melancholy as a tenuous border between neurosis and psychosis, as characterized by Freud, turns out to be a manner of replacing the conflict between reality and subject. The conflict, besides being obscured and dampened, although active, continues expressing the possibilities of Eros in its relationship with the death drive.
\end{abstract}

Keywords: identification, narcissism, melancholy, object 


\section{SUMÁRIO}

INTRODUÇÃO . .07

\section{CAPÍTULO 1: A constituição do Eu na relação com o objeto}

1.1As pulsões, o narcisismo e a natureza do objeto na psicanálise .24

1.2 Entre o mundo externo e a realidade psíquica: a relação entre o ideal do Eu e o narcisismo .31

$1.3 \mathrm{O}$ Eu e o dualismo pulsional: Eros e pulsão de morte .43

$1.4 \mathrm{O}$ masoquismo erógeno e originário e os desdobramentos de uma disjunção pulsional. .51

\section{CAPÍTULO 2: Identificação e Formação do Supereu}

2.1 O complexo de Édipo e o complexo de castração: as bases do Supereu .59

$2.2 \mathrm{O}$ Supereu - uma parte mais ou menos integrada ao $\mathrm{Eu}$ - entre a libido sublimada e a destrutividade. 65

2.3 A identificação e a função de síntese do ideal do Eu: as vicissitudes libidinais ..............................74

2.4 A severidade do Supereu: o sentimento de culpa e a necessidade de punição ..................................86

\section{CAPÍTULO 3: Melancolia}

3.1. Caracterização da melancolia. .93

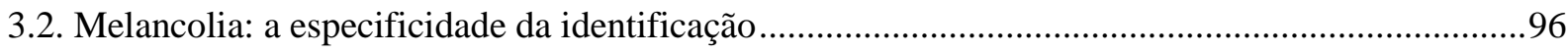

3.3 A ambivalência primordial e as vicissitudes libidinais na melancolia .........................................102

3.4 A mania e o complexo melancólico: a contraface da melancolia .................................................112

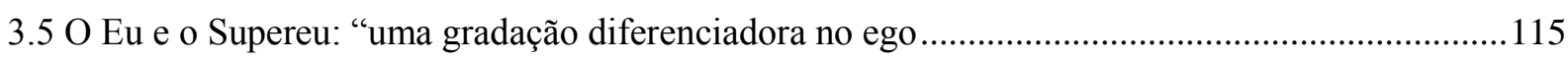

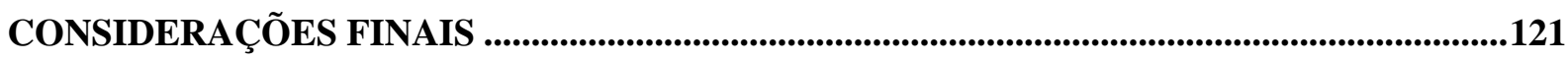

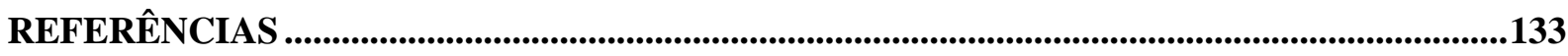




\section{INTRODUÇÃO}

O presente trabalho objetiva compreender a relação entre a identificação e o narcisismo na melancolia e surgiu de inquietações que permaneceram atuantes desde o desenvolvimento da dissertação de mestrado ${ }^{1}$. O interesse deriva de um percurso anterior de interrogações acerca do conceito de cultura na obra de Freud, tomando-a não exclusivamente como o domínio da natureza realizado pelos homens através da técnica e da ciência, mas, sobretudo, como expressão da necessidade humana de um "mais além" que transcenda o domínio do conquistado no domínio da própria natureza. Se, aparentemente, os temas parecem distantes, e o são, o que os aproxima é da ordem de uma dualidade que diz respeito à relação entre o sujeito e a cultura e, portanto, também entre o sujeito, o objeto e suas vicissitudes libidinais.

O conceito de cultura em Freud - que não separa cultura e civilização, embora não os tome como termos intercambiáveis - refere-se à tentativa de domínio humano sobre a natureza, interna e externa. No âmbito dessa produção e constituição humanas, também a busca de um "mais além" se institui no sujeito e para além dele, representando-se e instituindo-se na cultura e no sujeito em sua dualidade característica. Trata-se de uma tentativa de domínio sobre a natureza e, diga-se de passagem, sobre a própria natureza, que produz o anseio em dominar o que não se deixa apreender. Entre o anseio e a realização ou entre a fonte e o objeto da pulsão ${ }^{2}$ se constituem o sujeito e a cultura, numa luta de vida e morte, que se cria e recria internamente, nos meandros do sujeito psíquico.

\footnotetext{
${ }^{1}$ Dissertação intitulada Cultura e Repressão: entre a universalidade, a singularidade e as possibilidades da condição humana apresentada ao Programa de Pós- Graduação em Educação Brasileira da Faculdade de Educação da Universidade de Goiás no ano de 2005.

2 A nomenclatura adotada no texto para referir-se à repressão e ao instinto (estímulo), tal qual traduzida por Paulo César de Souza, foi recalque e pulsão. No trabalho, esses termos foram traduzidos para recalque e pulsão, a partir da consulta da tradução mais recente de Pedro Heliodoro Tavares.
} 
O "mais-além" expressa um anseio psíquico em realizar o que não se completou e representa-se no sujeito numa luta incessante entre Eros e pulsão de morte. Eros, imprimindo novas tensões em um percurso pulsional que tende à morte, movimenta o sujeito em direção ao domínio da própria sexualidade. Entretanto, na impossibilidade de o $\mathrm{Eu}^{3}$ representar-se psiquicamente como parte de Eros, a sexualidade pode tornar-se um investimento precocemente afastado do $\mathrm{Eu}$, que o mobiliza sem aquiescê-lo. O desdobramento desse processo é que, de forma predominante, o Eu defende-se da sexualidade antes mesmo de buscar sobre ela certo domínio, valendo-se, para isso, da própria força de Eros em consonância com a pulsão de morte.

O "mais-além", anseio psíquico de realizar o que não se completou, deriva da própria condição de emergência do sujeito. Trata-se de um quantum pulsional que impele o sujeito a criar, adoecer, amar, morrer, viver. É essa força, denominada por Freud (1915 a/2013) de pulsão, que se encontra na origem das criações humanas que, de sua vez, se encontram na origem da vida. Entretanto, sabe-se que a própria vida, surgida da tentativa de domínio da força pulsional, introduz nesse percurso novas tensões, novos caminhos, que impelem às vicissitudes que a tornam mais complexa, "conservando-a, naturalmente”. Essa é a função de Eros, que tem por finalidade dominar a morte e o desconhecido, aquiescendo-se deles.

A pulsão de morte tem por finalidade restabelecer um estado anterior. Modificando-a, Eros introduz um estado de conservação mais complexo que aspira, ao mesmo tempo, a continuação da vida e também a morte, tornando-se a própria vida uma luta e compromisso entre essas duas tendências (Freud, 1923 a/2011). Nesse sentido, a forma como essas tensões

\footnotetext{
${ }^{3} \mathrm{~A}$ nomenclatura usada para a denominação das instâncias psíquicas (Eu, Id, Supereu) refere-se à tradução da obra de Freud realizada por Paulo César de Souza, a primeira em língua portuguesa traduzida do original alemão. Outras traduções também foram utilizadas no desenvolvimento do trabalho, entre elas: a de Marilene Carone, do texto Luto e Melancolia, traduzida do alemão; a Edição Standart Brasileira das Obras Psicológicas Completas de Freud, de Strachey, traduzida do inglês; e a tradução publicada em 2013 por Pedro Heliodoro Tavares das Obras Incompletas de Freud, também traduzida do alemão. O único texto consultado dessa última tradução foi As Pulsões e seus destinos, a partir do qual se privilegiou neste trabalho a nomenclatura pulsão e recalque. Em razão disso, as citações são apresentadas ao longo do trabalho referenciando a tradução consultada em cada caso, embora, no corpo do texto, se tenha privilegiado a nomenclatura adotada por Paulo César de Souza (Id, Eu e Supereu) e a da segunda tradução direta do alemão realizada por Pedro Heliodoro Tavares (recalque e pulsão).
} 
originárias da vida são vividas e significadas pela criança, que vem ao mundo dependente e apetente, são decisivas nos caminhos posteriores tomados em busca da satisfação libidinal. Disso também depende a forma como as primeiras necessidades pulsionais do sujeito são satisfeitas, imprimindo nessas uma marca que o impulsiona a representar-se e a reconhecer-se na satisfação pulsional, sempre parcial.

A vida humana, entendida pelo que é da ordem das criações humanas, tal como a cultura, e ainda pela forma como essa criação estrutura-se e recria-se psiquicamente no sujeito, diz respeito à constituição de um objeto interno responsável pela organização libidinal. A distância entre a fonte e o objeto da pulsão, aquele que a satisfaz, é sublinhada por Freud (1915 a/2013) em A Pulsão e seus Destinos e representa o elemento que mantém a constância da força pulsional e a impossibilidade de seu domínio completo. A organização psíquica tem por finalidade a manutenção da mobilidade pulsional para que o objeto seja buscado e a pulsão parcialmente satisfeita, embora o objeto que a satisfaz seja sempre contingente, porque originariamente perdido.

A compreensão de Freud (1915 a/2013) sobre a contingência do objeto na psicanálise, apresentada desde $O s$ Três Ensaios sobre a sexualidade, constitui-se elemento fundamental na compreensão da organização psíquica. A contingência do objeto é o que possibilita a manutenção da mobilidade pulsional necessária à descarga de tensão, através da qual a pulsão encontra uma satisfação sempre parcial.

Porque a satisfação é parcial e a pulsão constante, o objeto faz-se contingente, constituindo-se, entretanto, parte do Eu, ao sobreviver enquanto desejo para além dele. $\mathrm{O}$ objeto torna-se responsável pela conservação e satisfação do Eu, ali mesmo onde, contraditoriamente, a satisfação torna-se irrepresentável enquanto objeto, porque incompleta. Essa experiência ocasiona, junto ao prazer da satisfação, o desprazer e a frustração, decorrentes de um objeto desde sempre perdido, porque "outro". 
O ensaio Sobre a Transitoriedade pode ser tomado como emblema do que é a contingência do objeto na psicanálise e de sua importância no que concerne à existência do desejo como o que permanece do objeto no Eu. O fato de que o objeto de investimento na estruturação do Eu seja imprescindível não o faz permanente e imutável. A possibilidade de um "desenvolvimento do Eu", nunca de forma linear e acabada, pressupõe a marca deixada pelo objeto de satisfação que possibilita à pulsão, primordialmente, vincular-se (ligar-se) a uma representação. No entanto, a representação é sempre insuficiente para a exigência de satisfação libidinal e descarga, o que torna constante a mobilidade pulsional.

Pontalis (2005) refere-se à experiência do que é transitório, passageiro e efêmero como algo que se liga, em primeiro lugar, com o efeito da felicidade, que é um encontro com o instante. A ideia da alegria está presente em Freud (1916 a / 2010) ao afirmar que o "valor de transitoriedade é valor de raridade no tempo". Segundo ele, "era incompreensível que o pensamento sobre a transitoriedade da beleza interferisse na alegria que dela derivamos" (Freud, 1916 a/2010, p. 249). Ressalta, nessa ideia, a ligação entre a transitoriedade e a alegria como experiência que pressupõe que o objeto deixa impressa uma marca definitiva, ainda que instantânea, possibilitando um registro mnêmico, que sobrevive ao objeto, fazendo do objeto um objeto contingente.

A experiência do efêmero e do passageiro é sempre melancólica por sua característica de antecipação do luto e, portanto, de uma perda. Entretanto, se essa experiência melancólica é constitutiva, ela é também "em primeiro lugar efeito da felicidade" (Pontalis, 2005). Esse "encontro com o instante" tem a ver com a experiência de um tempo que possui a marca de um registro, cuja representação se faz ausente enquanto lembrança construída, mas presente como traço de memória. 
A consideração de Pontalis (2005) sobre a marca que institui no psiquismo uma presença se delimita bem pela definição que ele apresenta de transferência, algo cujo destinatário sempre é incerto, mesmo que não restem dúvidas quanto à sua existência.

Ao referir-me a este tempo outro sem conseguir circunscrevê-lo, referindo-me a ele só em termos negativos (o que não é, o que tem de diferente), o que estou fazendo é, sem dúvida, falar simplesmente de transferência (...) Transferência que - não o ignoramos - excede a pessoa do analista e é igualmente excessiva em relação a qualquer outra figura real ou imaginária do passado. Transferência fora de toda figura, fora do tempo e fora da linguagem. Um modo de ação, um Agieren, dizia Freud. Uma paixão-ação, exigente, intensamente atual, mas sem idade (Pontalis, 2005, p. 15).

A transferência enquanto um modo de ação intensamente atual, mas sem idade, fundamenta-se na marca deixada pelo objeto. Essa marca é ponto de partida para uma primeira organização libidinal em que o Eu, a partir de um traço deixado pelo objeto, traça um caminho, podendo identificar-se primariamente como um objeto de investimento. É certo que o Eu, ainda em formação a esse tempo, não pode ainda significar essa satisfação na medida em que não pode dela distinguir-se. No entanto, é essa primeira representação que constitui a possibilidade da experiência corpórea e unificada da autoconservação, que possibilita ao Eu experienciar-se como um objeto de prazer e, posteriormente, renunciar a parte dessa satisfação como meio de autopreservar-se.

A melancolia, entretanto, é uma afecção psíquica que expressa, em um caminho contrário, a presença de uma ausência. A ausência de uma representação que não se inscreveu psiquicamente, embora permaneça presente enquanto traço. $\mathrm{O}$ objeto perdido na melancolia é substituído pela identificação, porque se torna irrenunciável no melancólico, suturando um vazio sem representação. A presença do objeto irrenunciável no Eu possibilita ao melancólico refugiar-se da morte e existir como objeto de desejo, embora o Eu não se possa representar como sujeito desejante e tampouco desejado. Nesse sentido, a melancolia deixa aberta a 
questão de que a impossibilidade de desligar-se de um objeto perdido vincula-se a uma impossibilidade do Eu de representar-se como um objeto de satisfação.

A transferência, segundo Pontalis (2005), é sempre a marca de um tempo que traz consigo o que se repete. "O que se repete — não digo o que se rumina, senão o que insiste - é aquilo que não teve lugar, que não encontrou seu lugar e que, por não conseguir advir, não existiu como acontecimento psíquico" (Pontalis, 2005, p. 19). Na melancolia e nas neuroses de transferência, a repetição é sempre a possibilidade de advir a ausência, marca essencial do desejo. No entanto, é preciso diferenciar a repetição do desejo da repetição do desejo de repetição (compulsão à repetição), ainda que a primeira envolva sempre a compulsão como busca do que não se inscreveu psiquicamente. A melancolia fornece caminhos para essa distinção, abrindo um campo de reflexão para as implicações da pulsão de morte nos caminhos de Eros.

Entende-se que a melancolia, enquanto emblema, representa uma afecção psíquica que coloca em evidência sobretudo a impossibilidade de desligar-se de um objeto de amor perdido. Nessa condição, expressa em seus desdobramentos a dificuldade do enfrentamento com a castração, necessário à constituição de um objeto interno ao Eu e determinante nos rumos da identificação. Sabe-se que o enfrentamento com a castração impõe-se ao sujeito no tempo do complexo edipiano e institui-se como renúncia ao objeto de amor no intuito de garantir a autoconservação narcísica. Nesse sentido, a renúncia ao objeto de amor abre diferentes e importantes questões aos caminhos da identificação e, portanto, da libido desinvestida do objeto.

Freud, ao definir a identificação como a "ação de assemelhar um ego a outro ego, em consequência do que o primeiro ego se comporta como o segundo, em determinados aspectos, imita-o e, em certo sentido, assimila-o dentro de si” (Freud, 1933 a/1974, p. 82), distingue a identificação da escolha objetal. Ele afirma que ambas são, em grande parte, independentes 
uma da outra, embora também seja possível, em alguns casos, que ambas coincidam. Se a primeira define-se por tomar o objeto como modelo para o $\mathrm{Eu}$, a partir do qual o Eu se transforma, trata-se então de um sujeito para o Eu; na escolha objetal, define-se um objeto para o Eu.

No intuito deste trabalho, é fundamental distinguir a identificação enquanto uma alteração do Eu conforme o modelo do objeto, seja ele um objeto distinto do objeto da escolha objetal ou o próprio objeto que se constitui também como objeto de amor para o Eu, coincidindo, no segundo caso, a identificação e a escolha objetal. A diferença entre identificação e escolha objetal é que a segunda não implica uma alteração do Eu, enquanto, na primeira, essa modificação é o que a define.

A segunda questão importante ao desenvolvimento do trabalho é compreender se a transformação do Eu a partir do objeto tomado como modelo representou para o Eu uma renúncia ao objeto de amor em benefício da autoconservação narcísica do Eu, ou se, a par a transformação do Eu pela identificação ao objeto, a libido dele retirada permanece inalterada. Essas questões são importantes para pensar, juntamente com os rumos da identificação na melancolia, os diferentes destinos da pulsão, entre eles: a sublimação, o recalque, o retorno em direção à própria pessoa e a reversão em seu contrário (Freud, 1915 a/2013).

Em Sublimação e Escrita, Menezes (1988) trata a sublimação como meio de transformação da pulsão sexual. Essa alusão à sublimação é importante nesse contexto por evidenciar que a modificação da pulsão sexual por uma alteração de sua meta envolve não a renúncia à energia sexual, embora esta se transforme, mas, sobretudo, a renúncia ao objeto e a suspensão da pulsão em seu fim sexual direto.

Menezes refere-se ao não-sexual como algo que preserva em suspenso o destino da pulsão, que, enquanto "fonte constante, implica sim a perene criação de energia sexual" (Menezes, 1988, p.77). Para Freud (1914a/2010), também a sublimação refere-se a uma 
modificação no âmbito pulsional, devendo, portanto, ser separada conceitualmente do processo de idealização, que diz respeito ao objeto. Se a sublimação é uma alteração da pulsão e suspensão do fim sexual direto, a alteração não pressupõe, portanto, a perda da excitabilidade pulsional.

O não-sexual não é nenhum valor em si mesmo. Não é um estado do reconhecimento. O não-sexual é deriva suspensiva do fim sexual. Ora, o sexual, considerado enquanto fonte constante, implica sim a perene criação de energia sexual, ou seja, a tentativa de sustentação em aberto do próprio processo de excitação pulsional. O que está em jogo é a natureza mesma da pulsão e seus avatares. A repetição que insiste liga-se ao trauma. Daí ser o fracasso resultado necessário e condição de sublimação (Menezes, 1988, p. 8).

O fracasso da repetição, para o qual a perda e a frustração podem ser elementos ativadores, é condição para que a pulsão tome um destino diferente do circuito substitutivo que sustenta o sintoma nas neuroses de transferência ou em outras inibições, como a melancolia. O trauma que não fracassa se repete como sintoma na neurose, ou então como excitabilidade inalterada na transferência que, sob a forma da angústia sem representação, apresenta-se como amortecimento e imobilismo na melancolia.

A sublimação vincula-se, sobretudo, à possibilidade de transformação da pulsão. A partir do trauma, que se constitui também como experiência melancólica por envolver a experiência de perda e desamparo, a pulsão alterada em sua meta, embora não em sua finalidade sexual, pode tecer, através da repetição, um caminho diferente do anteriormente estabelecido pelo automatismo da repetição. A pulsão sublimada (transformada em sua meta) quebra a constância da qual derivam os investimentos, podendo tomar caminhos diferentes na busca da satisfação do desejo.

A sublimação no estudo da melancolia é importante por colocar em pauta, pela negativa, dois elementos fundamentais que se encontram impedidos ou enfraquecidos. São 
eles: a não transformação da pulsão que, não modificada em sua meta, não pode se dirigir para o mundo externo, equacionando-se no âmbito do próprio Eu; e a impossibilidade da suspensão da meta sexual direta, que impede o fracasso de uma vinculação libidinal e, portanto, inviabiliza a renúncia pulsional. É possível pensar que a finalidade da sublimação, tal qual tratada na obra freudiana, envolve a possibilidade de domínio e participação do Eu nos destinos da libido retirada do objeto, podendo, através da renúncia ao objeto e aquiescência do Eu pela identificação, oferecer-se ao Id como objeto e participar de seus investimentos objetais. Entretanto, o domínio do Eu sobre a libido e a participação nos investimentos libidinais do Id através da identificação são radicalmente distintos do aprisionamento da libido nos estreitos limites do Eu.

Nesse sentido, a transformação da libido, que se expressa na sublimação, mas não se resume a ela, podendo também levar a outros destinos pulsionais, envolve um fracasso da repetição enquanto ligação da pulsão a um objeto e, portanto, à experiência de perda. Se o fortalecimento do Eu é condição para a sublimação no sentido de que é necessário ao Eu participar dos investimentos objetais do Id para ser possível (ou não) suspendê-los, adiá-los ou impedi-los, paradoxalmente, a sublimação, enquanto alteração da meta pulsional, sempre direta, por um desvio dos investimentos libidinais do Id, encontra-se presente também no processo de fortalecimento do Eu através da formação do ideal, embora permaneça sendo um processo distinto da idealização do objeto.

A identificação ao objeto na melancolia, embora ofereça, através de uma alteração do Eu, uma representação para o conflito entre o Eu e o objeto, representa-se para o melancólico como um conflito entre o Eu e o Supereu. Desse modo, ainda que a identificação represente uma modificação do Eu, não possibilita a canalização da libido para outros investimentos, visto que, da ligação entre o Eu e o Supereu na melancolia, depende, sobretudo, a autoconservação do Eu. 
A alteração do Eu, possível pelo viés da identificação, é importante para pensar a distinção não somente sobre as neuroses de transferência e a melancolia, mas também entre a neurose e a psicose no que se refere à relação entre a identificação e os destinos libidinais e entre o Eu e o mundo externo nas diferentes formas de organização psíquica.

Em seu texto Neurose e Psicose, Freud (1924 a/2011) afirma que o Eu é caracterizado por seus múltiplos laços de dependência e por sua posição intermediária entre o mundo exterior e o Id, o que reforça o seu empenho em fazer a vontade de todas as suas instâncias ao mesmo tempo. No entanto, essa função do Eu fracassa constantemente e esse fracasso é caracterizado, de forma mais contundente, nas patologias, seja na neurose, na psicose ou em outras afecções psíquicas, como a afecção melancólica.

O fracasso da função do Eu é inevitável, sendo impossível conciliar de forma harmônica os interesses narcísicos e os objetais e tampouco os interesses da sexualidade e do mundo externo. No entanto, ao questionar-se sobre as circunstâncias e meios pelos quais “o Eu consegue sair, sem adoecer, de tais conflitos que sempre se acham presentes" (Freud, 1924 a/2011, p.182), Freud refere-se à necessidade de investigar outros fatores, entre eles a relação de dependência do Eu frente ao Supereu, além de lançar a dúvida sobre qual seria o mecanismo, análogo à repressão, “mediante o qual o Eu se separa do mundo exterior”. Sem dúvida, o resultado das diversas situações dependerá da "constelação econômica, das grandezas relativas das tendências em luta” (Freud, 1924 a/2011, p.182).

O inconciliável conflito entre as exigências pulsionais e o Eu envolve o recalque e, portanto, a separação entre as pulsões de fim inibido e as pulsões não inibidas em sua finalidade. Essa separação equaciona-se a partir da constituição do Supereu. As formas de defesa que derivam do conflito inconciliável expressam que o recalque tem por finalidade impedir a satisfação completa da libido dirigida ao objeto, de modo a possibilitar a satisfação 
substitutiva e a autoconservação do Eu. Nesse sentido, o recalque impõe uma renúncia ao objeto, ainda que não necessariamente uma alteração da meta pulsional a ele dirigida.

Nessa direção, para preservar uma satisfação substitutiva, a libido recalcada pode encontrar diferentes vias substitutivas, que dependem também da forma como se deu o processo de identificação. No intuito de garantir a satisfação impedida pela realidade, a libido pode recuar para os objetos do $\mathrm{Eu}$, levando o Eu a distanciar-se da realidade, embora não do objeto interno (ideal do Eu) já constituído. O Eu, regredindo à fantasia, distancia-se da realidade sem alterá-la. Esse caminho de recuo frente à realidade caracteriza-se de forma mais precisa nas neuroses de transferência.

Nas parafrenias, o processo é outro. A retirada da libido dos objetos de investimento não é substituída pelos investimentos nos objetos da fantasia que, como na neurose, de alguma forma evidenciam a constituição primitiva de um objeto interno ao Eu para o qual a libido regride em caso de frustração com a realidade. Na parafrenia, a libido regride ao Eu. Por meio dessa regressão, o Eu desliga-se da realidade, buscando, contudo, alterá-la conforme seus interesses para que ela, de forma alucinatória, possa atender às suas reivindicações libidinais. O Eu se cinde, assumindo as reivindicações do Id e defendendo-se da realidade por meio de sua negação.

Na melancolia, essa cisão, mesmo que envolva também a regressão da libido ao Eu, parece ser de outra ordem. A ruptura do Eu seria antes expressão de uma cisão entre o Supereu e o Eu, em que o primeiro, a par de que se torne parte do Eu, não pode garantir a este uma reserva narcísica que proviria da formação de um ideal do Eu, derivado do narcisismo primitivo, mas também da internalização da realidade. Identificando-se ao objeto perdido sem, entretanto, distinguir-se dele através da formação de um ideal do Eu, o Eu divide-se para defender-se da libido, que a ele retorna com a identificação ao objeto. Uma parte da libido é empregada na identificação ao objeto perdido e a outra sofre a ação do recalque. A função do 
Supereu seria, nesse caso, defender-se, por uma intensificação do recalque, da pulsão agressiva que retorna ao Eu junto com a libido. Se a libido é o que mantêm a identificação ao objeto, cabe ao Supereu defender o Eu da agressividade que a ele retorna, exercendo, através do sadismo e da moralidade, a rígida função de consciência na qual o Eu se trata como objeto pelo viés da identificação ao objeto perdido. Sabe-se que a pulsão de morte encontra vias de canalização para o mundo externo através das pulsões eróticas. Nesse sentido, quando estas permanecem represadas no $\mathrm{Eu}$, este divide-se no intuito de exercer tanto a função de manutenção da libido como a de defesa à pulsão de morte que ao Eu retorna. Ainda que a realidade represente-se no Eu como moralidade, uma vez que oferece ao Eu a possibilidade de defender-se de suas pulsões agressivas, a realidade não pode representar-se no Eu como meio de satisfação.

O comportamento do Supereu deve, segundo Freud (1924 a/2011), ser considerado em todas as formas de doença psíquica, ainda que existam afecções diretamente baseadas num conflito entre o Eu e o Supereu. "A análise nos dá o direito de supor que a melancolia é um exemplo típico desse grupo, e reivindicaríamos para esses distúrbios o nome de ‘psiconeuroses narcísicas'. E não destoa de nossas impressões que encontremos motivos para separar estados como a melancolia de outras psicoses" (Freud, 1924 a/2011, p. 181).

O intuito deste trabalho de buscar a imbricação entre o narcisismo e a identificação na melancolia parte do suposto de que há nesta uma falha no que concerne à distinção de um objeto para o Eu, embora a falha não impeça a presença marcante de um objeto ausente. Os indicativos que sustentam a suposição se encontram estabelecidos em Luto e Melancolia, texto de Freud que se refere a essa afecção psíquica no contraponto da definição do luto. De forma geral, ambos colocam em questão a dificuldade de desvincular-se de um objeto perdido. 
Assim, para percorrer os caminhos necessários à compreensão da imbricação entre o narcisismo e a identificação na melancolia, é a seguinte a organização do texto. No primeiro capítulo, fundamenta-se, a partir da referência a Freud, as articulações necessárias à compreensão da relação entre as pulsões, o narcisismo e a natureza do objeto na psicanálise. Entende-se que essa relação se encontra em estreita ligação com o narcisismo, tempo inicial em que o Eu constitui-se como objeto de investimento. O intuito é pensar a organização dos processos primários através dos quais o Eu se constitui e encontra suas primeiras formas de satisfação mediadas pela relação entre o prazer e o desprazer.

Também, é no escopo da discussão sobre o narcisismo que o objeto na psicanálise se revela constitutivo também dos processos primários de estruturação do psiquismo, ainda que ele não se constitua, a princípio, um objeto interno para o Eu. Trata-se de uma organização libidinal que, efetuando-se entre o mundo interno e externo, mediada pelas sensações de prazer e desprazer, pode configurar uma unidade pulsional. Entretanto, se essa organização é necessária para que o Eu se constitua como um objeto de investimento, ela revela-se insuficiente para garantir a autopreservação do $\mathrm{Eu}$, de modo que, apesar da frustração implicada no abandono de um objeto de satisfação, torna-se necessário "começar a amar para não adoecer, e é inevitável adoecer, quando, devido à frustração, não se pode amar” (Freud, $1914 \mathrm{a} / 2010$, p. 29).

Quando o amor, entretanto, não pressupõe, a partir do complexo de Édipo, a renúncia a um objeto sexual primário, pode ocorrer de o $\mathrm{Eu}$ se dividir e afirmar-se, de forma ambivalente, como objeto no qual acabam por convergir o amor e o ódio. Esse seria o preço e a forma através dos quais o Eu obtém, pela regressão da libido, a convergência entre a satisfação sexual e a autopreservação. A impossibilidade de frustração que, na melancolia, evidencia-se na dificuldade de desligar-se do objeto perdido e, portanto, de renunciar a ele, 
coloca em cena destinos libidinais para os quais o Eu identificado ao objeto submete-se como objeto ao Supereu.

Ainda, este primeiro capítulo busca apreender, através da relação entre o ideal do Eu e o narcisismo, como se constituem para o Eu o mundo externo e a realidade psíquica como realidades em conflito, embora constituídas numa relação de dependência. Se, a rigor, o ideal do Eu se constitui apenas com a identificação resultante do complexo edipiano, sabe-se que também esse ideal preserva estreitos laços com o narcisismo. Esses laços iniciais serão trabalhados neste capítulo, embora retomados posteriormente para estabelecer a relação entre o Eu e o Supereu.

Freud não estabelece em sua obra uma diferenciação direta entre os conceitos de ideal do Eu e Supereu, embora também não tenha suprimido um termo em detrimento do outro. Neste trabalho, entende-se que a manutenção dos dois termos tem por princípio preservar a tensão entre ambos e, por isso, privilegiou-se o uso de ambos em situações distintas. Se o ideal do Eu revela-se, nos textos freudianos, uma das funções do Supereu, sabe-se, ademais, que o Supereu, na ausência do ideal enquanto instância interna capaz de representar no Eu as exigências narcísicas de autoconservação e o mundo externo, torna-se defesa ante a pulsão agressiva que não pode ser de outra forma canalizada para o mundo externo.

O segundo capítulo, intitulado "Identificação e a formação do Supereu", pretende, de forma ampla, fundamentar-se na formação do Supereu como instância representativa no Eu dos investimentos narcísicos abandonados e da realidade externa. Para isso, retoma a definição, a importância e a complexidade dos desenvolvimentos do complexo de Édipo e do complexo de castração no que concerne à estruturação psíquica e aos destinos libidinais.

Discute-se também, neste capítulo, a relação entre o Supereu e o ideal do Eu enquanto importante função dessa instância psíquica que possui, entre outras, também a consciência e a auto-observação. Nessa relação, tensionam-se o lugar do Eu entre suas diversas instâncias 
constitutivas e a possibilidade de este apropriar-se ou não de parte da libido retirada do objeto de amor abandonado a partir do complexo de Édipo. Nesse sentido, coloca-se em evidência a função da castração como tempo e interdito determinante na constituição do Supereu e, portanto, também dos destinos do complexo edipiano.

Enfatiza-se ainda o papel do ideal do Eu quanto a uma síntese possível e sempre parcial entre a libido do $\mathrm{Eu}$, a libido objetal e os investimentos objetais do Eu, representando a melancolia uma falha na estruturação do Supereu em sua possibilidade de constituir-se através do ideal do $\mathrm{Eu}$, interdito e aquiescência do $\mathrm{Eu}$ em suas demandas de autoconservação. Representaria o Supereu no melancólico a função de defesa direta aos investimentos primários do Id. Nesse ponto, evidencia-se que a severidade excessiva do Supereu no melancólico expressa, em sua violência, também a destrutividade primária não canalizada pelo Eu.

Fundamentando-se na compreensão do sentimento de culpabilidade e na necessidade de punição advinda do Eu, características da tensão entre o Eu e o Supereu e que não se restringem à afecção melancólica, abre-se o caminho para introduzir a questão da melancolia no que concerne à imbricação entre o narcisismo e a identificação. A constatação freudiana, expressa em $O$ mal estar na civilização de que toda renúncia a uma pulsão agressiva exige novas, constantes e sucessivas renúncias pulsionais, aumentando a severidade do Supereu, faz-se um elemento importante para pensar a especificidade da identificação na melancolia.

Afinal, nesse aspecto, o elemento distintivo é que a identificação no melancólico, apesar de levar a uma transformação do Eu, não significa uma renúncia pulsional ao objeto de amor perdido. Assim, somente a pulsão agressiva que não pode ser dirigida para o mundo externo a partir da identificação seria recalcada, de modo que a libido que retorna ao Eu teria a função de manter a ligação erótica entre o Eu e o Supereu, sustentada pela satisfação masoquista do Eu. 
Por fim, o terceiro capítulo toma a melancolia como expressão de uma afecção psíquica que, por encontrar-se na obra freudiana entre a neurose e a psicose, recoloca questões que se encontram no limite entre ambas. Nesse lugar fronteiriço, expressa, através dos desdobramentos da identificação, as falhas no que respeita à constituição do Supereu, que remetem, desde o princípio, ao narcisismo e à função determinante desse primeiro tempo de organização libidinal do Eu.

A melancolia lança luz, portanto, ao lugar da identificação no que concerne à organização narcísica primitiva do psiquismo e aos rumos possíveis do narcisismo e dos investimentos objetais do Eu. Sabe-se que o objeto, ainda que indistinto do Eu, revela-se determinante já nos processos primários do $\mathrm{Eu}$, em que, para este representar-se como objeto de investimento, é condição determinante que possa, antes, reconhecer-se como um objeto de investimento.

Nesse sentido, a identificação estaria já em causa nos limites e possibilidades do sujeito de desejo. Ao expor a forma como se equaciona, em sua especificidade, a identificação e as formas de investimento que dela resultam, a melancolia coloca em cena também as possibilidades de identificação que se apresentam ao melancólico, determinantes quanto aos rumos do narcisismo e sua imbricação na melancolia.

No texto Neurose e Psicose, questionando sobre as possibilidades do Eu em sua relação com a realidade, Freud (1924 a/2011) interroga-se em que condições o Eu poderia constituir-se um intermediário mais próximo da realidade psíquica e externa, em que, não obstante dividido entre instâncias distintas, pudesse, valendo-se da força do Id, poupar a si mesmo o recalque.

E para o Eu será possível evitar a ruptura em qualquer direção, ao deformar a si mesmo, permitir danos à sua unidade, eventualmente até se dividir ou partir. Desse modo as incoerências, excentricidades e loucuras dos homens apareceriam numa luz semelhante à de suas perversões sexuais, cuja aceitação lhes permite poupar a si mesmo repressões (Freud, 1924 a/2011, p.182-183). 
Freud (1924 a/2011) certamente não se refere, nessa afirmação, ao lugar e à função ocupada pelo Eu na melancolia. Refere-se, entretanto, a outra posição do Eu que, embora envolva cisões e separações e, portanto, a relação de dependência do Eu ao Supereu e ao Id, possibilita ao Eu "poupar a si mesmo repressões". Entende-se que a afirmação de Freud (1924 a/2011) remete à ideia de um menor distanciamento entre as exigências pulsionais, o Eu e seus investimentos objetais, embora não a uma ausência de distinção entre eles. A sublimação como um destino pulsional, tal qual envolvida na identificação, que supõe uma alteração da meta pulsional e, portanto, a renúncia a um objeto de amor, sugere um caminho não de conciliação e ausência de recalque, mas de participação do Eu nos investimentos objetais do Id e também na satisfação derivada desses investimentos.

A relação com a realidade externa é, então, questionada através da melancolia em seu limiar entre a neurose e a psicose. Sem romper com a realidade externa, mas também não se disponibilizando libidinalmente a ela, a melancolia denuncia uma realidade de certo modo estéril, ou seja, presente, mesmo que ausente. Trata-se de uma realidade que transforma o sujeito psiquicamente, embora não possa afetá-lo libidinalmente. A libido torna-se a forma de manter-se ao objeto vinculado, embora o prazer derivado dessa ligação se restrinja a uma satisfação destrutiva para o Eu. A satisfação masoquista do Eu torna-se a maneira através da qual Eros mantém-se atuante, defendendo-se do ódio pela intensificação da rigidez do Supereu. Se a destrutividade do Supereu denuncia a atuação da pulsão de morte, as formas de satisfação eróticas obtidas na melancolia denunciam os riscos impostos a Eros quando a realidade torna-se estéril ao Eu, embora atuante. 


\section{CAPÍTULO 1: A CONSTITUIÇÃO DO EU NA RELAÇÃO COM O OBJETO}

\subsection{As pulsões, o narcisismo e a natureza do objeto na psicanálise}

A constituição do psiquismo numa tensa relação entre o Id, fonte desorganizada das pulsões, e o Eu em suas relações com o mundo interno e externo pressupõe uma primeira forma de organização e estruturação antes inexistente. O psiquismo constitui-se a partir de um tempo de espera imposto à criança para a satisfação de suas primeiras necessidades. A espera é o que impulsiona à representação do objeto de satisfação e essa representação tem por finalidade escapar à angústia advinda da ausência de representação e de uma excitação proveniente de estímulos internos e externos.

O tempo, 'tecido de nossa vida' no dizer de Antônio Candido, é também a condição ontológica do psiquismo. A qualidade que define o psíquico não é espacial, é temporal; daí a dificuldade dos neurocientistas em localizar, no tecido cerebral, o inconsciente freudiano. A inclusão da dimensão temporal, sob a forma subjetiva da espera de satisfação, marca a origem do sujeito psíquico. A primeira manifestação da onipotência do Outro primordial, para o infans, consiste em submeter a urgência da satisfação das necessidades do recém-nascido a uma certa demora. $\mathrm{O}$ psiquismo se instaura a partir do trabalho de representação do objeto de satisfação esperado, na tentativa de anular o angustiante intervalo de tempo vazio" (Kehl, 2009, p. 111-112).

A necessidade de satisfação não tem tempo. É originariamente instantânea e exige descarga imediata. O que a insere na ordem psíquica, tornando-a pulsional, é o tempo de espera, que exige do psiquismo um trabalho de representação do objeto de satisfação esperado. O tempo da espera, adiamento da satisfação, é uma quebra da linearidade absoluta do princípio do prazer. A satisfação de uma necessidade coincide com a redução de parte da tensão experienciada. Ao mesmo tempo, a experiência de satisfação deixa como registro no psiquismo uma excitabilidade advinda de um acréscimo de energia. Esse acréscimo 
impulsiona ao anseio da repetição da experiência de satisfação que, a partir de então, não busca exclusivamente a redução da tensão gerada pela necessidade, mas visa à consecução do prazer que, temporariamente, pode significar um adiamento da satisfação e, portanto, uma elevação da tensão experienciada como desprazer.

Na criança recém-nascida, não há distinção entre o objeto de satisfação e o próprio corpo. Suas catexias objetais também não se distinguem dos seus objetos de investimento. A satisfação das necessidades de autopreservação leva ao anseio de representar essa experiência de satisfação no intuito de conservá-la. Nesse movimento, o acréscimo de energia fornecido pela satisfação pulsional impulsiona à unificação das pulsões até então investidas no prazer do órgão de forma parcial, direcionando-as posteriormente à unificação pulsional.

O funcionamento psíquico constitui-se no momento em que o circuito de descarga das excitações provenientes de dentro do organismo deixa de atuar de maneira exclusivamente reflexa, passando a envolver a intervenção do aparelho mental. Em Mais Além do Princípio do Prazer, questionando-se sobre a natureza dos processos excitatórios vinculados à constituição psíquica, Freud (1920a/1974) afirma que se sabe muito pouco sobre a natureza desses processos excitatórios que se efetuam nos elementos dos sistemas psíquicos. No entanto, afirma:

(...) temos de distinguir entre dois tipos de catexia dos sistemas psíquicos ou seus elementos: uma catexia que flui livremente e pressiona no sentido da descarga e uma catexia quiescente. Podemos suspeitar de que a vinculação da energia que flui para dentro do aparelho mental consiste em sua mudança de um estado de fluxo livre para um estado quiescente" (Freud, 1920 a/1974, p. 46-47).

Uma energia que muda de um estado de fluxo livre para um estado quiescente ao fluir para dentro do aparelho mental pressupõe a existência da vinculação de uma excitabilidade pulsional a uma sua representação. Esse momento coincide com o tempo de espera da satisfação à qual a criança está submetida e que a impulsiona a buscar em si a representação 
desse objeto de satisfação, vinculando a essa representação parte da excitabilidade pulsional antes em estado de fluxo livre. A representação de um objeto de satisfação é, portanto, condição para que o psiquismo possa beneficiar-se dessa experiência e nela tomar parte.

A satisfação propicia a redução da tensão advinda da necessidade e imprime no Eu, além disso, uma experiência de intensidade que tem a ver, originariamente, com a modificação de um estado de tensão. A modificação é sentida psiquicamente como experiência agradável de prazer, ainda que dela reste um quantum que não se satisfaz. Essas experiências são simultâneas e deixam como resquício uma marca no psiquismo que torna o objeto, enquanto o que viabiliza a satisfação, algo necessário à experiência de prazer.

A relação existente entre o prazer e o desprazer exige a caracterização mais detalhada sobre o objeto de satisfação. O objeto na psicanálise é uma das referências utilizadas em parceria com outros termos para definir a pulsão. Seriam eles: a pressão, a finalidade e a fonte. Para Freud, o objeto "é aquele junto ao qual, ou através do qual a pulsão pode alcançar a sua meta. É o que há de mais variável na pulsão, não estando originariamente a ela vinculado, sendo apenas a ela atribuído por sua capacidade de tornar possível a satisfação” (Freud, 1915a/2013, p. 58).

O objeto a que Freud se refere como "algo" que viabiliza a satisfação possui uma característica importante no que concerne à mobilidade pulsional. O objeto é sempre contingente, pode ser modificado inúmeras vezes no decorrer das diversas vicissitudes sofridas pela pulsão durante sua existência, e a característica de deslocamento da pulsão desempenha funções importantes no funcionamento psíquico. O objeto pode constituir-se como sendo o próprio corpo ou parte deste, desde que propicie satisfação. A mobilidade pulsional apresenta-se como característica marcante, ainda que, em determinados casos, possa haver o que Freud nomeia de "fixação". 
A caracterização da fonte das pulsões leva Freud, em As Pulsões e seus destinos, a defini-la como sendo de ordem endossomática, o que coloca a fonte pulsional em estreita conexão com o aparato orgânico. No que concerne à psicologia, aponta Freud (1915a/2013), trata-se de compreender melhor a conexão existente entre a fonte da qual provêm as pulsões em sua relação com a finalidade, ou seja, em conexão com as formas de satisfação. No entanto, apontando uma caracterização geral das pulsões sexuais, afirma:

São numerosas, advêm de múltiplas fontes orgânicas, agem inicialmente de forma independente umas das outras e só depois se reúnem em uma síntese mais ou menos acabada. A meta a que cada uma delas aspira é a obtenção do prazer do órgão; somente após terem completado a síntese é que se põem a serviço da função reprodutiva, pela qual se tornam geralmente reconhecíveis como pulsões sexuais. Em sua primeira manifestação, apoiam-se inicialmente nas pulsões de conservação, das quais apenas aos poucos se desligam, e seguem também na busca do objeto os caminhos indicados pelas pulsões do Eu (Freud, 1915 a/2013, p. 33).

O questionamento sobre a natureza pulsional leva Freud a buscar a resposta no que é primevo, original, abstendo-se de buscá-la numa variedade de definições classificatórias. A análise das psiconeuroses evidencia o que se encontra na raiz das afecções psíquicas: o conflito entre o Eu e a sexualidade, independentemente das formas singulares tomadas nas neuroses de transferência.

No intuito de apreender a natureza pulsional e aprofundando-se nas questões do narcisismo, movido pelo estudo das parafrenias, Freud aproxima-se da relação antes tomada pela psicanálise em segundo plano: a constituição do Eu em sua relação com as forças pulsionais. Nessa direção, o objeto na psicanálise, tomado, desde 1905, em Três Ensaios Sobre a sexualidade, a partir da ênfase em sua contingência e a partir da compreensão das relações objetais estabelecidas de forma anaclítica, ganha outra perspectiva a partir do estudo do narcisismo. O Eu, antes compreendido sobretudo na dimensão de uma instância que tinha 
como função a defesa frente à sexualidade, torna-se, a partir da compreensão do narcisismo, o primeiro objeto de investimento sexual.

Os estudos de outras afecções psíquicas, denominadas por Freud (1914 a/2010) de psiconeuroses narcísicas, e também das parafrenias possibilitam o desenvolvimento de estudos e questões que se ligam à compreensão do narcisismo. O texto Narcisismo: uma introdução é decisivo para a compreensão da natureza do Eu como objeto da pulsão. O narcisismo, como investimento do Eu ainda em formação, revela-se ponto de ancoragem da sexualidade, e a compreensão de que o primeiro objeto investido pelas pulsões, de forma sexual, é o Eu propiciou mudanças decisivas na compreensão do campo pulsional em sua vinculação com os aspectos identificatórios da constituição do psiquismo.

No texto, Freud (1914 a/2010) refere-se a duas formas de escolhas objetais que, embora não se excluam, consistem em mecanismos distintos. São as escolhas objetais narcisistas e anaclíticas. $\mathrm{O}$ estudo das psiconeuroses fundamentou-se, durante longo tempo, na investigação e nos desdobramentos dos conflitos referentes às escolhas objetais anaclíticas ou do tipo "de apoio". Entretanto, descobriu-se que, originalmente, o ser humano "tem dois objetos sexuais: ele próprio e a mulher que o cria, e nisso pressupomos o narcisismo primário de todo indivíduo, que eventualmente pode se expressar de maneira dominante em sua escolha de objeto" (Freud, 1914 a/2010, p. 33).

A análise realizada por Freud sobre a vida amorosa dos seres humanos demonstra que as escolhas objetais tantas vezes expressam que o primitivo narcisismo não se tornou arrefecido, mas se reproduz nas escolhas amorosas através das quais o sujeito busca garantir a satisfação narcísica de um tempo primitivo. Freud (1914 a/2010) acrescenta que o amor objetal completo, do tipo "de apoio", é característico do homem, sendo as mulheres representantes mais próximas de um tipo de escolha objetal narcísica. O fundamento apresentado para essa preponderância de escolhas narcísicas nas mulheres sustenta-se no fato 
de que a maturação dos órgãos femininos, até então latentes, trazem à tona o narcisismo original, que não é propício à constituição de um regular amor objetal com supervalorização sexual do objeto de amor. Produz-se na mulher uma autossuficiência que parece lhe compensar a pouca liberdade de que desfruta em suas escolhas objetais. Entretanto, Freud (1914a/2010) esclarece que muitas mulheres amam segundo o modelo masculino e exibem, portanto, a superestimação sexual própria desse tipo.

Trata-se, portanto, menos de uma distinção entre as formas de amor no que concerne à diferença entre homens e mulheres, mas, sobretudo, de uma ênfase dada por Freud (1914 a/2010) na caracterização de um modelo de amor que reproduz sobre a forma de um narcisismo secundário um narcisismo originário e que, em geral, encontra-se presente, com diferenças quanto à intensidade com que se manifesta, mesclado às escolhas objetais "de apoio", no homem e na mulher.

O amor objetal completo é definido por Freud (1914 a/2010) como aquele que "exibe a notória superestimação sexual, que provavelmente deriva do narcisismo original da criança, e corresponde assim a uma transposição do mesmo para o objeto sexual” (Freud, 1914a/2011, p. 33). Este é o estado propício para o surgimento do amor em que se constata também um empobrecimento libidinal do $\mathrm{Eu}$ em favor do objeto. $\mathrm{O}$ amor narcísico, ao contrário, demonstra não ser propício a essa superestimação sexual. A libido é investida, nesse caso, em um objeto semelhante ao próprio sujeito, de modo que este busca, na relação amorosa, o que ele mesmo é ou o que ele mesmo foi, o que gostaria de ser ou uma pessoa que foi parte dele mesmo.

Busca-se, na escolha objetal narcisista, ser amado, não tendo tanta importância amar, o que justifica ser esse tipo de amor pouco propício à superestimação sexual. É interessante ressaltar que a forma como Freud (1914 a/2010) aborda o fascínio que o sujeito narcisista exerce sobre aquele que está em busca de uma escolha objetal demonstra que também o amor 
objetal do tipo "de apoio" ancora-se sobre um narcisismo originário, que não deixa nunca de exercer certo fascínio sobre aqueles que dele abdicaram. "É como se os invejássemos pela conservação de um estado psíquico bem-aventurado, uma posição libidinal inatacável, que desde então nós mesmos abandonamos" (Freud, 1914 a/2010, p. 34).

Pois parece bem claro que o narcisismo de uma pessoa tem grande fascínio para aquelas que desistiram da dimensão plena de seu próprio narcisismo e estão em busca do amor objetal; a atração de um bebê se deve em boa parte ao seu narcisismo, sua auto-suficiência e inacessibilidade, assim como a atração de alguns bichos que parecem não se importar conosco, como os gatos e os grandes animais de rapina; e mesmo o grande criminoso e o humorista conquistam nosso interesse, na representação literária, pela coerência narcísica com que mantêm afastados do seu Eu tudo que possa diminuí-lo (Freud, 1914a/2010, p. 34).

A permanência do narcisismo como um estado de satisfação do Eu, do qual o sujeito abdica apenas parcialmente, é descrita também por Freud (1914a/2010) a partir da constatação da atitude terna de muitos pais para com seus filhos. "Temos de reconhecê-la como revivescência e reprodução do seu próprio narcisismo há muito abandonado" (Freud, 1914 a/2010, p. 36). A superestimação dos filhos denota uma transferência de um estigma narcísico que domina a relação afetiva.

A diferença que se observa entre o narcisismo dos pais revivido na relação com os filhos e o próprio narcisismo perdido é que os pais tantas vezes tendem a suspender, face à criança, as limitações que foram impostas ao seu próprio narcisismo, de forma que, "no ponto mais delicado do sistema narcísico, a imortalidade do Eu, tão duramente acossada pela realidade, a segurança é obtida refugiando-se na criança". A esta torna-se permitido o que foi, de certo modo, impedido aos seus pais. (Freud, 1914a/2010, p. 37).

Tendo ressaltado a importância do narcisismo que, mesmo quando renunciado como estado de satisfação do Eu, permanece como um ideal que se expressa e se representa parcialmente nas escolhas amorosas do sujeito, Freud (1914a/2010) acrescenta ser necessário 
compreender as perturbações às quais o narcisismo originário é exposto desde cedo. As defesas empregadas para defender-se dessas perturbações são fundamentais à organização do psiquismo e também à determinação das diferentes afecções psíquicas.

O complexo de castração associado com a intimidação sexual exercida sobre a criança são momentos decisivos, segundo Freud (1914 a/2010), para a compreensão dos destinos libidinais, quando estes, isolados das pulsões do Eu, acham-se em oposição a elas. De qualquer modo, acompanhando esses destinos libidinais, é possível "fazer inferências sobre uma época e uma situação psíquica em que as duas classes de instintos surgem como interesses narcísicos, ainda operando em concerto e inseparavelmente unidas" (Freud, 1914 a/2010, p. 38).

\subsection{Entre o mundo externo e a realidade psíquica: a relação entre o ideal do Eu e o narcisismo}

A relação com o mundo externo no período autoerótico da vida psíquica é bastante peculiar. Nesse período, a satisfação é encontrada no próprio corpo, inicialmente representada no prazer do órgão. Nesse momento, o mundo, psíquica e primordialmente, é indiferente para a pulsão, ainda que lhe seja fundamental. A forma da satisfação pulsional é autoerótica, embora tenha se revelado insuficiente para garantir as necessidades das experiências sofridas pelas pulsões de autopreservação.

Sabe-se que a experiência de satisfação da necessidade de autopreservação imprime um acréscimo de energia ao Eu ainda em formação, que o impele a reagir a essa mesma experiência. A constituição do $\mathrm{Eu}$ depende, portanto, da passagem de um estado de autoerotismo e completa indiferença ao mundo externo para o narcisismo. Neste, as relações entre os investimentos objetais do Id representado pelas pulsões e o mundo configuram-se não 
mais de forma completamente independente, mas adquirem uma primeira organização mediada pelo princípio do prazer. Freud (1914a/2010) refere-se a uma ação psíquica que impulsiona à passagem do estado de autoerotismo para o narcisismo primário.

(...) Uma unidade comparável ao Eu não existe desde o começo no indivíduo; o $\mathrm{Eu}$ tem que ser desenvolvido. Mas os instintos autoeróticos são primordiais; então deve haver algo que se acrescenta ao autoerotismo, uma nova ação psíquica, para que se forme o narcisismo (Freud, 1914a/2010, p. 18-19).

Essa ação psíquica está ligada ao acréscimo de energia ao Eu, que o impulsiona a reagir a uma experiência com o objeto de satisfação para o qual ainda não há representação. Essa relação se estrutura a partir da forma como a criança acolhe em seu Eu, primordialmente, as experiências de prazer e desprazer. A criança não distingue primordialmente o seio que a alimenta e o próprio corpo. Quando o seio é separado do seu corpo, este carrega consigo, sob a forma de um "objeto", os investimentos libidinais nele investidos. A impossibilidade de manter a satisfação na ausência do objeto faz com que o Eu sinta seus estímulos pulsionais internos como desprazerosos por algum tempo, o que o impulsiona a reagir internamente a essa experiência.

Sob o domínio do princípio do prazer ocorre nele um novo desenvolvimento. Ele toma para si, em seu Eu, os objetos oferecidos, desde que eles sejam fontes de prazer, introjeta-os (de acordo com a expressão de Ferenczi) e, por outro lado, expele o que dentro dele se torna causa de desprazer (Freud, 1915 a/2013, p. 53).

Essa primeira organização que se estabelece no psiquismo é ponto de partida para a diferenciação entre o Eu e o mundo externo, o que não significa ainda, imediatamente, a distinção entre o Eu e o objeto. A completa indiferença pulsional ao mundo externo, associada à forma de satisfação autoerótica, é substituída, com o narcisismo, pela unificação das pulsões 
em torno do $\mathrm{Eu}$, que, identificado ao prazer de uma experiência de satisfação, representa-se como objeto de satisfação, afastando temporariamente de si o desprazer.

No narcisismo, a forma de satisfação permanece autoerótica, encontrada no corpo investido pelas pulsões. No entanto, torna-se um estágio marcado pela unificação das pulsões parciais. Se não há ainda uma distinção inicial entre a criança e a mãe que a satisfaz, sabe-se, entretanto, que o investimento da mãe na criança é fundamental para que ela possa identificarse como um objeto de satisfação, representado como experiência de prazer. Configura-se um estágio em que a formação do Eu é concomitante à indiferenciação entre os investimentos pulsionais advindos do Id e da libido do Eu. A autopreservação torna-se indissociada da sexualidade.

O investimento libidinal do Eu constitui-se, para a criança no estado do narcisismo primário, como experiência de prazer. A relação entre o Eu erotizado e o mundo externo é vivida, psiquicamente, pela experiência de prazer-desprazer, que, nesse movimento, oferece à pulsão certa regularidade na satisfação. A busca da constância é alcançada pela unificação Eu/objeto de prazer. É o momento de conversão do "Eu da realidade original"- taxativo em sua indiferença ao mundo externo - em "Eu do prazer purificado". Trata-se não mais da relação entre o que está dentro e o que não existe (mundo externo), mas entre o agradável e o desagradável (Freud, 1915a/2013), o que sustenta uma primeira modificação no psiquismo.

As sensações agradáveis são, então, incorporadas ao Eu e as sensações desagradáveis, originadas também dentro do Eu, são expelidas para fora, já que se tornam causa de desprazer. A experiência de desprazer, mesmo que seja projetada para fora do Eu, não lhe é mais indiferente e provém de estímulos pulsionais internos. Há uma reprodução da polaridade Eu-mundo externo, que é vivida psiquicamente na relação com o prazer/desprazer.

No texto As Pulsões e seus Destinos, Freud distingue o narcisismo do autoerotismo, definindo o primeiro como um estado do Eu e o segundo, como uma forma de satisfação. "O 
Eu se encontra originalmente, bem no início da vida anímica, pulsionalmente ocupado, estando, em certa medida, em condições de satisfazer suas pulsões em si mesmo. Denominamos essa condição de narcisismo, e tal possibilidade de obter satisfação, de autoerótica” (Freud, 1915 a/2013, p. 53).

$\mathrm{O}$ Eu, na medida em que é autoerótico, não tem necessidade do mundo exterior, mas recebe dele objetos, devido às vivências das pulsões de autopreservação, e não pode deixar de sentir os estímulos pulsionais internos por certo tempo como desprazerosos (Freud, 1915 a/2013, p. $53)$.

O Eu torna-se, portanto, o objeto de satisfação, restando-lhe, entretanto, uma parte que lhe é estranha e inassimilável, que não está fora e que não se pode poupar de forma permanente. Ao mesmo tempo, a partir do narcisismo, o Eu torna-se objeto das pulsões e se aquiesce em suas forças, que toma de empréstimo dos investimentos objetais do Id. A condição de tornar-se objeto das pulsões (narcisismo primário) é concomitante à possibilidade de a elas não sucumbir, à razão de conseguir certo domínio (defesa) sobre elas a partir da força tomada de empréstimo do Id, de modo a organizá-las internamente, acolhendo-as em si ou expelindo-as conforme o princípio do prazer/desprazer.

As sensações de desprazer, se expelidas do Eu, permanecem como parte dele. As experiências de prazer e de desprazer do Eu impedem o equacionamento da satisfação libidinal no interior do próprio Eu. Se o Eu torna-se, de forma permanente, o próprio objeto de satisfação, contraditoriamente essa experiência impede que ele possa desfrutar dessa satisfação através da descarga para um aumento de uma tensão libidinal. O objeto de satisfação deve, portanto, deslocar-se do Eu para garantir sua autopreservação, garantindo também a mobilidade pulsional.

Se a libido mantém-se vinculada integralmente ao Eu, este pode sucumbir aos fins diretos da pulsão sexual, ou seja, sucumbir à descarga pulsional. Para que não ocorra tal 
destino, novos investimentos são visados pelo $\mathrm{Eu}$, que se beneficia desses investimentos de forma indireta e parcial. Além disso, a transformação de parte da libido do Eu em libido objetal proporciona a descarga para o quantum pulsional excedente que não encontra vinculação no Eu.

\begin{abstract}
Após a fase puramente narcisista dar lugar à fase objetal, o prazer e o desprazer significam relações do Eu com o objeto. Quando o objeto se torna uma fonte de sensações prazerosas, estabelece-se uma tendência motriz que, trazendo-o para mais perto, procura incorporá-lo ao Eu; falamos então da "atração" exercida pelo objeto que proporciona prazer e dizemos, portanto, que "amamos" esse objeto. Inversamente, quando o objeto é uma fonte de sensações desprazerosas, uma tendência se esforça para aumentar a distância entre ele e o Eu, para repetir, em relação a ele [objeto], a tentativa original de fuga em face do mundo externo emissor de estímulos. Sentimos a "repulsa" do objeto, e o odiamos; esse ódio pode, depois, se intensificar a ponto de tornar-se uma propensão à agressão contra o objeto, uma intenção de aniquilá-lo (Freud, 1915 a/2013, p. 55-57).
\end{abstract}

O caminho que se segue da relação entre o estágio puramente narcísico ao tempo da identificação edipiana é conduzido pela questão esboçada por Freud (1914a/2010), em Narcisismo: uma introdução, sobre saber "de onde vem mesmo a necessidade que tem a psique de ultrapassar as fronteiras do narcisismo e pôr a libido em objetos" (Freud, 1914a/2010, p. 29). Ao que ele responde: “Um forte egoísmo protege contra o adoecimento, mas afinal é preciso começar a amar, para não adoecer, e é inevitável adoecer, quando, devido à frustração, não se pode amar” (Freud, 1914a/2010, p. 29).

A relação entre a libido e seus objetos de satisfação passa por vários estágios e é experienciada nesses de formas diferentes quanto aos seus investimentos e obtenção de satisfação. Se, primordialmente, a satisfação é encontrada no corpo erotizado, tornando-se este um primeiro objeto para as pulsões, posteriormente os investimentos são dirigidos para os objetos representados pelo Eu. 
O narcisismo cumpre um papel de organização pulsional e de organização do Eu e nunca é completamente abandonado. No narcisismo, o Eu se reconhece como um Eu-prazer, tornando-se um estado primitivo e determinante no desenvolvimento libidinal para o qual a libido pode, inclusive, retroceder. Permanece, portanto, como traço psíquico que se apresenta de forma arrefecida nas escolhas objetais, podendo tornar-se mais determinante em alguma dessas escolhas e na própria estruturação psíquica.

Em Narcicismo: uma introdução, Freud (1914a/2010) questiona-se sobre o destino dado aos traços psíquicos no adulto a partir dos quais se constatou o seu narcisismo infantil. Considerando que sua megalomania de outrora foi arrefecida, pergunta-se sobre o que teria acontecido à sua libido do Eu. "Devemos supor que todo esse montante passou para investimentos de objeto? Essa possibilidade contradiz evidentemente o veio de nossas discussões; mas podemos tomar à psicologia da repressão também uma pista para outra resposta à pergunta" (Freud, 1914a/2010, p. 39).

A compreensão do destino libidinal é importante por colocar em pauta o desenvolvimento libidinal e a estruturação do $\mathrm{Eu}$ como processos interligados. O desenvolvimento libidinal não envolve a superação de estágios anteriores da libido, de modo que as formas mais antigas de organização libidinal permanecem atuantes sobre as novas configurações, embora modificadas pelas exigências do princípio da realidade. Os processos primários do $\mathrm{Eu}$ regidos pelo princípio do prazer tornam-se submetidos aos processos secundários que envolvem uma maior organização e subsunção dos investimentos desorganizados do Id ao Eu e à realidade.

A formação do ideal do Eu como uma instância psíquica que se desenvolve do Eu fornece elementos que corroboram a tese freudiana de que os processos primários permanecem atuantes no psiquismo, embora modificados. Essa instância tem a função de preservar libidinalmente parte da satisfação narcísica da qual, outrora, o Eu se beneficiou. O 
recalque às pulsões libidinais torna-se, a partir da identificação que resulta do complexo edipiano, função assumida pelo Eu. Entretanto, mesmo que o Eu se reconheça nos ideais morais e culturais que toma para si a partir da identificação, não significa que o recalque seja suficiente para que o indivíduo renuncie completamente à satisfação uma vez desfrutada.

Ele não quer se privar da perfeição narcisista de sua infância, e se não pode mantê-la, perturbado por admoestações durante seu desenvolvimento e tendo seu juízo despertado, procura readquiri-la na forma nova do ideal do $\mathrm{Eu}$. O que ele projeta diante de si como seu ideal é o substituto para o narcisismo perdido da infância, na qual ele era seu próprio ideal (Freud, 1914a/2010, p. 40).

A compreensão freudiana do narcisismo apresentada em Narcisismo: uma introdução parte, em certo ponto, do acompanhamento dos destinos libidinais quando isolados da libido do Eu. A partir desses destinos, é possível fazer inferências, como afirmado, sobre uma época e uma situação psíquica em que a libido do $\mathrm{Eu}$ e a libido objetal operam de forma inseparáveis. As fases de desenvolvimento da libido que antecedem a organização completa da função sexual precedem a fase genital concluída apenas na puberdade.

Se, nas primeiras fases dos investimentos libidinais (Freud, 1938a/1974), os diferentes componentes da libido investem na busca de prazer de forma independente uns dos outros, sabe-se que, na fase fálica, encontram-se os primórdios da organização que subordina os outros impulsos "à primazia dos órgãos genitais e determina o começo de uma coordenação do impulso geral em direção ao prazer na função sexual" (Freud, 1938a/1974, p. 180), o que supõe um desvio da meta da satisfação sexual direta que, entretanto, nem sempre ocorre, podendo a libido tomar vários destinos. O prazer na função sexual refere-se menos ao prazer ligado à satisfação direta da libido, mas, sobretudo, à conservação da função sexual, para a qual o objeto é fundamental, embora contingente. 
A organização completa só se conclui na puberdade, numa quarta fase, a genital. Estabelece-se então um estado de coisas em que (1) algumas catexias libidinais primitivas são retidas, (2) outras são incorporadas à função sexual como atos auxiliares, preparatórios, cuja satisfação produz o que é conhecido como pré-prazer, e (3) outros impulsos são excluídos da organização, e são ou suprimidos inteiramente (reprimidos) ou empregados no ego de outra maneira, formando traços de caráter ou experimentando a sublimação, com deslocamento de seus objetivos (Freud, 1938a/1974, p. 180-181).

O primeiro objeto investido pelo Eu é a mãe ou quem exerça essa função, sendo este investimento ligado à função de nutrição e autopreservação. $\mathrm{O}$ importante a ser ressaltado nesse processo é o deslocamento da libido para um objeto separado do Eu. As relações anteriormente estabelecidas entre o prazer e o desprazer cedem lugar à relação entre o Eu e o objeto. O objeto é considerado pelo Eu conforme sua necessidade de satisfação de autopreservação. Não há ainda, nesse momento de relação entre o Eu e o objeto, nenhuma contradição entre, por exemplo, desejar a mãe como objeto de satisfação e identificar-se ao pai em sua força e onipotência. Essas experiências coexistem e não são contraditórias para a criança.

O objeto reconhecido como separado do Eu tem a função de possibilitar, além da satisfação, em parte desviada do Eu, a função de uma elaboração psíquica interna para as excitações que não são capazes de uma descarga externa direta, ou para as quais essa descarga é indesejável no momento. Sem essa descarga, as excitações seriam sentidas como penosas ou de efeito patogênico (Freud, 1914a/2010, p. 30). Se o objeto representa para o Eu a satisfação de seus impulsos libidinais, resta também uma insatisfação derivada da experiência de não ser o objeto parte do próprio Eu. O objeto cumpre, portanto, a função de promover internamente uma elaboração psíquica para os anseios ambivalentes do Eu.

A elaboração psíquica para Freud (1914a/2010) pressupõe uma ligação da libido a uma representação do objeto de satisfação real ou imaginário, sendo, a princípio, indiferente se a elaboração ocorre em um ou em outro. O estudo das parafrenias em sua relação com o 
narcisismo acena para a importância da elaboração psíquica como meio de lidar com as excitações para as quais a fuga, tal qual realizada em relação aos estímulos externos, é ineficiente. $\mathrm{O}$ estudo do narcisismo evidencia que a elaboração psíquica pode ser realizada tanto em objetos reais como imaginários, sendo a diferença entre eles determinada somente $a$ posteriori e referente a um narcisismo secundário edificado sobre um narcisismo primário.

A identificação ocorrida com a dissolução do complexo de Édipo resulta numa tentativa de elaboração psíquica. Esta deixa como legado a formação de um representante interno ao Eu das relações parentais abandonadas e do mundo externo, constituindo-se um modelo para o Eu. A formação do ideal do Eu é uma tentativa de preservar internamente o objeto de amor, afastando-se da finalidade direta de satisfação sexual. Esse modelo, o ideal do $\mathrm{Eu}$, torna-se parte mais ou menos integrada ao $\mathrm{Eu}$ e envolve também os primeiros investimentos abandonados em seus objetos de amor.

O ideal do Eu resulta do reconhecimento do complexo de castração, que consiste na ameaça à autopreservação do Eu. O desenvolvimento da criança e de seus impulsos libidinais primitivos a colocam em permanente confronto com a realidade e impedem que a criança prossiga sua relação onipotente com seus objetos de amor sem intempéries. A impossibilidade de identificar-se ao pai em sua força e onipotência e preservar a mãe como objeto sexual exige da criança uma renúncia à satisfação sexual direta dirigida ao objeto de amor. A renúncia ocorre porque a criança vislumbra, a partir da realidade, a ameaça à sua integridade narcísica caso permaneça na relação edípica com seus objetos. O resultado seria a perda do amor dos pais e o seu desamparo.

O reconhecimento da possibilidade de castração é fundamental por colocar a criança frente a frente com a realidade e com seus anseios de autopreservação narcísica. Identificar-se a um objeto tomando-o como modelo para o Eu torna-se uma forma de conservar a função sexual, desviando-a do objeto sexual. Trata-se de uma tentativa, através da formação do ideal 
do Eu, de conciliar a satisfação sexual deslocada de seu objeto direto e da preservação narcísica do Eu em sua onipotência.

A complexidade do processo advém dos resquícios deixados pela tentativa de conciliação que resultam na dupla função do ideal do Eu. A identificação da qual resulta o ideal do Eu consiste na internalização do modelo parental com o qual, outrora, o Eu rivalizava com seu objeto de amor. Sendo o objeto tomado como modelo para o Eu, ele torna-se parte deste, de modo que a hostilidade outrora dirigida a ele retorna com o objeto ao Eu.

Em certo sentido, o desvio da satisfação sexual direta leva ao reforço da identificação ao objeto tomado como modelo. Entretanto, o retorno da hostilidade ao Eu, sob a forma do ideal do $\mathrm{Eu}$, representa, internamente, a ambivalência outrora dirigida aos objetos. A hostilidade ao objeto com o qual o Eu rivalizava na disputa pelo objeto de amor retorna ao Eu com a instituição do ideal do Eu. Essa hostilidade justifica que o ideal do Eu represente não somente o ideal narcísico e a possibilidade de continuidade de uma satisfação abandonada, desviada em sua função direta, mas também a incitação ao recalque de parte das pulsões sexuais.

Não seria de admirar se encontrássemos uma instância psíquica especial, que cumprisse a tarefa de assegurar a satisfação narcísica a partir do ideal do $\mathrm{Eu}$ e que, com esse propósito, observasse continuamente o Eu atual, medindo-o pelo ideal. Havendo uma tal instância, será impossível para nós descobri-la; poderemos apenas identificá-la e constatar que o que chamamos de nossa consciência moral tem essas características. O reconhecimento dessa instância nos torna possível compreender o que chamam delírio de ser notado ou, mais corretamente, observado, que surge de maneira tão clara na sintomatologia das doenças paranóides, podendo sobrevir também como doença isolada, ou entremeada na neurose de transferência (Freud, 1914a/2010, p. 42).

Nesse trecho, Freud (1914a/2010) apresenta outra função do ideal do Eu que, mais tarde, ele, em $O$ Eu e o Id, denominará de Supereu. A consciência moral, junto com o ideal do 
Eu e a auto-observação constituem, portanto, as funções do Supereu. A tutela do ideal do Eu foi confiada à consciência moral e a incitação a formar o ideal do Eu partiu da influência crítica dos pais, aos quais se agregam, no curso dos tempos, "educadores, instrutores e, como uma hoste inumerável e indefinível, todas as demais pessoas do meio (o próximo, a opinião pública)" (Freud, 1914a/2010, p. 42).

O caráter proibitivo do Supereu em sua função de incitar o Eu ao recalque torna-se, entretanto, mais explícito em $O$ Eи e o Id. Para Freud (1923a/2011), ele envolve tanto as primeiras escolhas objetais do Id como uma enérgica formação reativa a essas escolhas, constituindo-se com uma dupla face. "Sua relação com o Eu não se esgota na advertência: “Assim (como o pai) você deve ser"; ela compreende também a proibição: “Assim (como o pai) você não pode ser, isto é, não pode fazer tudo o que ele faz; há coisas que continuam reservadas a ele" (Freud, 1923a/2011, p. 42-43).

Em certo sentido, o preço da superestimação sexual do objeto que representa no ideal do Eu uma continuidade da satisfação narcísica é a renúncia ao objeto sexual. No entanto, apesar de que ocorra a renúncia ao objeto e a formação do ideal, não está garantido que o desvio da meta sexual implique uma alteração na forma de obtenção da finalidade sexual. Essa diferença será mais desenvolvida posteriormente, a partir da diferenciação entre a sublimação e a idealização na formação do ideal do Eu.

De forma breve e com o intuito de esclarecer a função do ideal do Eu, é possível afirmar que a distinção estabelecida por Freud (1914a/2010) entre a sublimação pulsional e a idealização do objeto tomado como modelo para o Eu marca a diferença entre a necessária formação do ideal do Eu e a sublimação. Se, a princípio, esses parecem processos que se complementam, sabe-se que a formação o ideal do Eu não é suficiente para fortalecer a sublimação. 
De um lado, a formação do ideal do Eu é necessária para que o Eu possa tolerar ou ao menos elaborar conscientemente algumas "impressões, vivências, impulsos e desejos" abandonados, que poderiam ser rejeitados por outras pessoas que não erigiram em si esse ideal. Nesse sentido, envolve uma elaboração psíquica por constituir-se a partir de um desvio da meta sexual de sua finalidade direta. De outro lado, não é condição suficiente para que possa ocorrer a sublimação de parte da libido desviada de sua meta sexual direta. Pode também ocorrer de a formação do ideal do Eu aumentar as exigências do Eu, favorecendo o recalque em detrimento da sublimação. "Haver trocado seu narcisismo pela veneração de um elevado ideal do Eu não implica ter alcançado a sublimação de seus instintos libidinais" (Freud, 1914a/2010, p. 41).

Freud (1914a/2010) apresenta exemplos clínicos de afecções psíquicas que demonstram que a elaboração psíquica, que é também uma função do ideal do Eu, ocorre, muitas vezes, de outra forma, em detrimento da libido objetal, podendo ter por consequência o represamento libidinal no Eu. O que significa dizer que, por algum motivo, a formação do ideal do Eu, responsável por uma elaboração interna para os investimentos libidinais, não resultou da sublimação (dessexualização) necessária que poderia levar ao investimento do Eu a partir de um desvio da libido objetal.

A megalomania, por exemplo, característica de algumas afecções parafrênicas, evidencia uma forma de elaboração psíquica distinta da que ocorre nas parafrenias, embora à custa da libido objetal. A libido, em caso de regressão, pode retornar ao Eu e permanecer nele represada, não retrocedendo, como nas neuroses de transferência, aos investimentos objetais abandonados pelo Eu. "A libido retirada do mundo externo foi dirigida para o Eu, de modo a surgir uma conduta que podemos chamar de narcisismo" (Freud, 1914a/2010, p. 16).

O estudo da parafrenia foi importante por acentuar dois momentos distintos do narcisismo, embora interligados: o narcisismo primário e o secundário. É este último "o 
narcisismo que surge por retração dos investimentos objetais como secundário, edificado sobre um narcisismo primário" (Freud, 1914a/2010, p. 16). A regressão ou a introversão da libido retirada dos objetos para o Eu ou para os investimentos objetais do Eu são indicativos de que a identificação ocorrida na dissolução do complexo edipiano pode implicar diferentes destinos libidinais que significam, de todo modo, diferentes formas e possibilidades de o sujeito colocar-se frente ao sofrimento psíquico. De qualquer modo, a possibilidade de uma regressão da libido ao Eu ou a introversão da libido para os investimentos objetais abandonados acentuam a importância da compreensão do narcisismo como um estado primitivo do $\mathrm{Eu}$.

\subsection{O Eu e o dualismo pulsional: Eros e pulsão de morte}

O caráter sexual do Eu constituído no narcisismo primário por um acréscimo de excitabilidade a partir do qual o Eu se representa como unidade é determinante para a compreensão de que o Eu é também sexual e constitui-se como um primeiro objeto para a libido, não possuindo somente a função de defesa frente à sexualidade. Ademais, constituindo-se estado originário na estruturação psíquica, o narcisismo torna-se determinante também na compreensão das neuroses, que evidenciam, para além de um conflito psíquico entre a sexualidade e o Eu, a vinculação da libido objetal à libido do Eu, indistintas a princípio.

Formamos assim a idéia de um originário investimento libidinal do $\mathrm{Eu}$, de que algo é depois cedido aos objetos, mas que persiste fundamentalmente, relacionando-se aos investimentos de objeto como o corpo de uma ameba aos pseudópodes que dela avançam. Essa parte da alocação da libido ficou inicialmente oculta para a nossa pesquisa, cujo ponto de partida eram os sintomas neuróticos. Notamos as emanações dessa libido, os investimentos de objeto que podem ser avançados e novamente recuados. Enxergamos também, em largos traços, uma oposição entre libido do Eu e libido de objeto. Quanto 
mais uma se emprega, mais empobrece a outra. A mais elevada fase de desenvolvimento a que se chega esta última aparece como estado de enamoramento; ele se nos apresenta como um abandono da própria personalidade em favor do investimento do objeto, e tem seu contrário na fantasia (ou autopercepção) de fim do mundo dos paranóicos. (Freud, 1914a/2010, p. 17).

O estudo das neuroses, que, até então, colocava em evidência a libido sexual em conflito com as pulsões de autopreservação, se insere no estudo das complexas relações do Eu, sendo a libido sexual, a partir disso, representada tanto pela libido do Eu quanto pela libido objetal. Esse acréscimo e modificação no enfoque sobre as neuroses a partir da descoberta do narcisismo como um estado primitivo colocam em cena, no âmbito de um "novo" conflito psíquico, a libido do Eu e a libido objetal.

No que se refere à sexualidade, trata-se não mais de compreendê-la apenas como em conflito com a libido do Eu, mas, sobretudo, como a função de Eros em conflito com a pulsão de morte que, por sua vez, evidencia-se, segundo Freud (1920a/1974), nas manifestações clínicas do impulso destrutivo do sadismo. Vale dizer que o dualismo que se desloca para a relação entre a libido do Eu e a libido objetal preserva o conflito anterior derivado da impossibilidade de conciliação entre ambas e evidencia o dualismo referente à própria natureza sexual.

Em Mais Além do Princípio do Prazer, Freud (1920a/1974) refere-se a um quantum pulsional que não possui representação senão quando vinculado a Eros. Eros, entretanto, representa-se como a indiferenciação entre a pulsão sexual e a libido do Eu. A pulsão de morte só pode ser percebida, portanto, quando deslocada de seu lugar de origem. Estando sob a influência da libido narcísica ou libido do Eu, torna-se manifesta, por exemplo, sob a forma preliminar do sadismo em relação aos objetos e não em relação ao Eu ${ }^{4}$. Entretanto, vale

\footnotetext{
${ }^{4} \mathrm{O}$ sadismo dirigido a um objeto é tratado em Mais Além do Princípio do Prazer como uma manifestação da pulsão de destruição, externalizada quando expulsa do Eu. O contraponto do sadismo, tal como trabalhado por Freud nesse texto, seria o masoquismo, pulsão complementar ao sadismo, que pode ser vista como um sadismo que se voltou contra o próprio Eu do sujeito. Entretanto, já nesse texto, Freud sugere uma discussão sobre o masoquismo constituir-se primariamente no $\mathrm{Eu}$, sendo a discussão desenvolvida e sustentada por ele em $O$ Problema Econômico do Masoquismo. Segue o trecho presente em Mais Além do Princípio do Prazer que sugere o início da discussão sobre um masoquismo primário. "Mas, em princípio, não existe diferença entre um
} 
lembrar que, como sinalizado, esses apontamentos colocam em cena uma organização libidinal e psíquica que pressupõe um investimento narcísico do Eu e investimentos primários do Eu que atuem também como anteparo à pulsão de morte.

Durante a fase oral da organização da libido, o ato de obtenção de domínio erótico sobre um objeto coincide com a destruição desse objeto; posteriormente, o instinto sádico se isola, e, finalmente, na fase da primazia genital, assume, para os fins de reprodução, a função de dominar o objeto sexual até o ponto necessário à efetivação do ato sexual. Poder-se-ia verdadeiramente dizer que o sadismo que foi expulso do ego apontou o caminho para os componentes libidinais do instinto sexual e que estes o seguiram para o objeto. Onde quer que o sadismo original não tenha sofrido mitigação ou mistura, encontramos a ambivalência familiar de amor e ódio na vida erótica (Freud, 1920a/1974, p. 74).

A descoberta do narcisismo pelo estudo das parafrenias auxiliou a constatação de que as pulsões sexuais em estado bem primitivo não se opõem à libido do Eu, embora possam unificá-las. A análise realizada por Freud (1924b/2011) sobre o masoquismo em seu texto O Problema Econômico do Masoquismo evidencia que a libido, a par de que seja sempre sexual quando investida no Eu ou direcionada para outros investimentos objetais, não é a única força atuante no psiquismo. Sabe-se que o princípio do Nirvana, pertencente à pulsão de morte, experimentou no ser vivo uma modificação que o fez tornar-se princípio do prazer.

Essa distinção é importante por explicitar a natureza da dualidade pulsional entre Eros e pulsão de morte. A princípio, a compreensão psicanalítica considerava a semelhança entre o princípio do prazer e o princípio de Nirvana concernente à meta de uma descarga direta da pulsão que propiciaria redução da tensão, coincidindo esta redução com a produção de prazer. Em O Problema Econômico do Masoquismo, entretanto, Freud (1924b/2011) explicita que o prazer e o desprazer não podem ser compreendidos, exclusivamente, como rebaixamento ou acréscimo de tensão. Ele afirma que, embora tenham muito a ver com isso, sua definição "não

instinto voltar-se do objeto para o ego ou do ego para o objeto, que é o novo ponto que se acha em discussão atualmente. O masoquismo, a volta do instinto para o próprio ego do sujeito, constituiria, nesse caso, um retorno a uma fase anterior da história do instinto, uma regressão" (Freud, 19120/1974 a, p. 75). 
depende desse fator quantitativo, mas de uma característica dele que só podemos designar como qualitativa" (Freud, 1924b/2011, p. 186).

Freud considera que a modificação experimentada pelo princípio de Nirvana transformou-o em princípio do prazer. Um acréscimo libidinal foi introduzido no percurso de deslocamento da pulsão em direção à descarga e teve como desdobramento no Eu em formação uma experiência de prazer a partir de uma elevação da tensão. "Não é difícil adivinhar de qual poder se originou essa modificação, se queremos prosseguir com este raciocínio. Pode ser apenas o instinto de vida, a libido, que desse modo conquistou sua parte na regulamentação dos processos vitais, junto ao instinto de morte" (Freud, 1924b/2011, p. 187).

O acréscimo de tensão que levou à modificação do princípio de Nirvana, transformando-o em princípio do prazer, faz com que o princípio de prazer represente as exigências da vida. Ao introduzir um acréscimo de tensão nos investimentos que se destinavam a uma descarga direta, a libido impõe um obstáculo à completa descarga pulsional. Vale lembrar que os três princípios a que Freud se refere - princípio do Nirvana, princípio do prazer e princípio da realidade, o último consistindo numa modificação no princípio do prazer - não se excluem uns aos outros.

Via de regra eles sabem tolerar um ao outro, embora ocasionalmente deva levar a conflitos o fato de a meta estabelecida ser, de um lado, a diminuição quantitativa da carga de estímulos, do outro, um caráter qualitativo da mesma, e, por fim, um adiamento da descarga e uma aceitação provisória da tensão devida ao desprazer (Freud, 1924b/2011, p. 187).

Em $O$ Eu e o Id, Freud (1923a/2011) refere-se à relação entre Eros e pulsão de morte, tomando-a como representante mais ou menos próxima das duas espécies de pulsões: o amor e ódio. Se a aproximação entre Eros e o amor pode ser mais evidente, a representação mais 
próxima para a pulsão de morte é o ódio. As manifestações clínicas apresentadas por Freud (1923a/2011) sugerem que “o ódio é não somente o inesperado acompanhante regular do amor (ambivalência), não apenas o seu frequente precursor nas relações humanas, mas também que o ódio, em várias circunstâncias, transforma-se em amor, e o amor, em ódio" (Freud, 1923a/2011, p. 53).

Essa característica evidencia a importância da mobilidade pulsional quanto à possibilidade de transformação da pulsão de morte em Eros como forma de descarga. No intuito de obter descarga, a pulsão pode juntar-se a um impulso erótico ou destrutivo e elevar o investimento total deste. Sabe-se que, quando ambos atuam de forma conjunta ou mesclada, a pulsão de morte associada a um impulso erótico pode voltar-se para o mundo externo. $\mathrm{O}$ exemplo fornecido por Freud refere-se ao sadismo. Quando este é apenas um componente da pulsão sexual, pode-se dizer de uma mescla pulsional através da qual o impulso destrutivo é dirigido para o mundo externo, visto que Eros atenua sua força.

No entanto, num caminho inverso, tem-se também o sadismo que se tornou independente como perversão. Este seria exemplo de uma disjunção pulsional que pode ter como consequência a intensificação de um impulso destrutivo que pode buscar sua forma de descarga de modo independente de um impulso erótico. Nesse caso, a pulsão de morte atuaria separada de Eros, tendo por finalidade uma descarga direta que só pode ser adiada ou suspensa temporariamente pela atuação de Eros como guardião da vida. No que concerne à mescla e à disjunção pulsional, Freud (1923a/2011) sintetiza:

Numa generalização rápida, conjecturamos que a essência de uma regressão libidinal, da fase genital à sádico-anal, por exemplo, baseiase numa disjunção instintual, e, inversamente, o avanço da fase genital inicial à definitiva tem por condição um acréscimo de componentes eróticos. Surge também a questão de que a ambivalência ordinária, que com frequência é fortalecida na disposição constitucional à neurose, pode ser apreendida como resultado de uma disjunção; mas ela é tão primordial que deve ser antes uma mescla instintual não consumada (Freud, 1923a/2011, p. 52). 
A questão levantada por Freud (1923a/2011) sobre a ambivalência primordial é importante para a compreensão do que estaria na origem de uma mescla ou de uma disjunção pulsional. Sabe-se que a conversão do amor em ódio ou do ódio em amor refere-se, tal qual tratado por Freud em $O$ Eu e o Id (1923a/2011), a uma mudança puramente interna e não envolve, necessariamente, a conduta do objeto. A atitude ambivalente em relação a um objeto está presente desde o início e relaciona-se, primordialmente, com a própria natureza qualitativa do princípio do prazer, que atua como uma derivação do princípio do Nirvana e transforma-se também pelo princípio da realidade. Em função disso, um mesmo objeto pode significar prazer e desprazer para o Eu e, portanto, ódio e amor. Segundo Freud (1915a/2013), é muito frequente encontrar o amor e o ódio "dirigidos simultaneamente para o mesmo objeto, sua coexistência oferece o exemplo mais significativo de uma ambivalência de sentimentos" (Freud, 1915a/2013, p. 49).

Essa duplicidade da natureza do objeto em sua relação com a pulsão justifica a ambivalência primordial entre o amor e o ódio. Não obstante, não é suficiente para elucidar a compreensão do que se encontra na origem de uma disjunção pulsional. Freud (1923a/2011) afirma que a transformação de uma atitude ambivalente, presente desde o início, pode ocorrer, por exemplo, por meio de um "deslocamento reativo do investimento, quando se subtrai energia do impulso erótico e se introduz energia no impulso hostil" (Freud, 1923a/2011, p. 54). Essa forma de transformação de uma atitude ambivalente está presente, para ele (1923a/2011), na mudança paranoica do amor em ódio e é expressiva por representar a possibilidade de transformação de uma atitude desde o princípio ambivalente como forma de obter uma descarga impedida de outro modo.

Na gênese da homossexualidade, mas também dos sentimentos sociais dessexualizados, a pesquisa psicanalítica nos deu a conhecer há pouco a existência de vigorosos sentimentos de rivalidade que levam a inclinações agressivas; somente após a superação deles o objeto antes odiado torna-se amado ou objeto de uma identificação. Cabe perguntar 
se nesses casos devemos supor uma conversão direta de ódio em amor. Trata-se aqui de mudanças puramente internas, em que não participam variações de conduta do objeto (Freud, 1923a/2011, p. 54).

Freud (1923a/2011) formula a hipótese de que a energia atuante no Id e no Eu seja Eros dessexualizado, provindo, portanto, da reserva de libido narcísica. Eros, quando se consuma como um acréscimo de energia ao $\mathrm{Eu}$, pode neutralizar o impulso destrutivo de modo a atenuá-lo, ocorrendo uma mescla pulsional entre Eros e pulsão de morte. Entretanto, o Eu, ao apoderar-se dos investimentos objetais do Id através da identificação ao objeto, transforma-se em seu único objeto de amor, promovendo também a disjunção entre Eros e pulsão de morte ao sublimar (dessexualizar) parte da libido.

Assim, se a reserva de libido narcísica origina-se com a sexualização do Eu, impelindo-o à apropriação da libido sexual como forma de manter-se como objeto de satisfação, é necessário também que o Eu possa diferenciar-se do objeto para não se tornar alvo do Id, embora deva participar também de seus investimentos. Se, por um lado, tem-se que a disjunção pulsional pode levar à atuação independente da pulsão de morte quando o Eu se oferece como um objeto de satisfação ao Id, por outro, tornando-se um objeto parcial para o Id, o Eu pode participar dos investimentos do Id.

$\mathrm{O}$ acréscimo de energia ao Eu ainda em formação constitui uma reserva a partir da qual, posteriormente, o Eu sofre novas modificações. A energia sublimada dos investimentos objetais do id "mantém a principal intenção de Eros, a de unir e ligar, na medida em que contribui para a unidade - ou o esforço por unidade - que caracteriza o Eu" (Freud, 1923a/2011, p. 57).

A importância da formação de uma reserva narcísica é que o Eu, aliado ao princípio do prazer, representa em si uma experiência de satisfação que lhe possibilita defender-se do desprazer e representar o prazer de modo a conservá-lo mesmo quando o objeto de satisfação se ausenta. As pulsões eróticas são mais deslocáveis, plásticas e desviáveis e trabalham para o 
princípio do prazer a fim de facilitar descargas e evitar o represamento. Tornando-se investido de libido, o Eu neutraliza em parte a pulsão de morte, necessitando, entretanto, "tolerar uma outra porção de investimentos objetais do Id, como que participar deles” (Freud, 1923a/2011, p. 57).

A finalidade da pulsão erótica conforme o princípio do prazer é facilitar a descarga e evitar represamentos, independentemente do caminho pelo qual sucede a descarga. Entretanto, quando o Eu identifica-se ao objeto de prazer, apropria-se de parte dos investimentos objetais do Id de modo a oferecer-lhes um destino: mantê-los, adiá-los ou suspendê-los temporariamente. "Seria próprio do Eu insistir numa maior exatidão na escolha do objeto e da via de descarga" (Freud, 1923a/2011, p.57).

Desse modo, a formação da reserva de libido narcísica pressupõe a indiferenciação entre libido do Eu e libido sexual, fortalecendo o Eros em conformidade com o princípio do prazer e o Eu que, apesar de impor desvios à libido, pode participar dos investimentos objetais eróticos do Id. Tornando-se sexualizado, também o Eu precisa encontrar uma forma de conservar parte dos investimentos do Id para si, mas também transformar-se para que a libido erótica deslocável possa encontrar satisfação. Nesse processo, parte da libido do Eu transforma-se em libido objetal pela mediação do Eu. Entretanto, Freud (1923a/2011) não desconsidera, nesse processo, o risco de uma disjunção pulsional - ou mesmo de uma não formação originária da mescla pulsional - responsável pela convergência entre pulsão sexual e libido do Eu.

A libido manifesta-se como sexual ao vincular-se a uma representação do objeto. $\mathrm{O}$ Eu, como objeto, desvia parte do investimento erótico do Id, anteriormente associado às pulsões desorganizadas que buscam descarga, diferenciando-se do Id e fazendo anteparo à pulsão de morte, que tem como meta a descarga imediata. A patologia em várias formas de afecções psíquicas resulta de uma regressão da libido que expressa os efeitos da disjunção pulsional. Compreende-se que o masoquismo, tal qual exposto por Freud em O Problema econômico do masoquismo, oferece elementos para pensar a disjunção pulsional. 


\subsection{O Masoquismo erógeno e originário e os desdobramentos de uma disjunção pulsional}

Os desenvolvimentos apresentados à teoria do narcisismo em $O$ Eu e o Id levam Freud (1923a/2011) a afirmar que o narcisismo do Eu é um narcisismo secundário, subtraído aos objetos. Freud sintetiza o processo afirmando que, inicialmente, “o Id envia parte dessa libido para investimentos objetais eróticos e, com isso, o Eu fortalecido procura apoderar-se dessa libido objetal e impor-se ao Id como objeto de amor" (Freud, 1923a/2011, p. 58).

O princípio do prazer serve ao Id como uma bússola no combate à libido, que introduz perturbações no curso da vida. Se, conforme Fechner, o princípio da constância governa a vida, que seria uma descensão na morte, são as exigências de Eros, dos instintos sexuais, que, enquanto necessidades instintuais, impedem a diminuição do nível e introduzem novas tensões. O Id, guiado pelo princípio do prazer, isto é, pela percepção do desprazer, defende-se dela por vários meios. Em primeiro lugar, pela rápida indulgência para com as reivindicações da libido não dessexualizada, ou seja, o empenho na satisfação das tendências diretamente sexuais. De modo bem mais amplo, numa forma particular dessas satisfações, em que convergem todas as exigências parciais, livrando-se das substâncias sexuais, que são veículos saturados, por assim dizer, das tensões eróticas (...) Finalmente, como vimos, o Eu facilita para o Id o trabalho de superação, ao sublimar parte da libido para si e seus fins (Freud, 1923a/2011, p. 59).

Se o narcisismo é secundário, subtraído aos objetos, sabe-se, no entanto, que as observações clínicas e o estudo das parafrenias evidenciam o narcisismo também como um estado primordial para o qual a libido pode retroceder. A compreensão dos diferentes destinos pulsionais, inclusive da pulsão de morte desvinculada de Eros, revela-se decisiva no estudo da melancolia como expressão de uma neurose narcísica.

O masoquismo, forma originária de satisfação da libido, traz contribuições importantes para o estudo da melancolia por revelar que a pulsão de morte, quando se torna independente 
de Eros, apresenta sua força no contraponto da pulsão de vida, embora através dela. "O masoquismo, a volta do instinto para o próprio ego do sujeito, constituiria, nesse caso, um retorno a uma fase anterior da história do instinto, uma regressão”. (Freud, 1920a/1974, p. 75). Desse modo, tem-se que também o Eu pode tornar-se objeto das pulsões sádicas, sucumbindo a elas.

A compreensão do masoquismo erógeno e original exposta por Freud em O Problema Econômico do Masoquismo pode lançar luz sobre a análise a ser realizada, no terceiro capítulo, sobre a importante relação ambivalente entre o amor e ódio na melancolia. $\mathrm{O}$ masoquismo se apresenta sobre três formas distintas: "como uma condição para a excitação sexual, como expressão da natureza feminina e como uma norma de conduta na vida (behavior)" (Freud, 1924b/2011, p.188). A partir dessas diferentes manifestações do masoquismo, Freud os define como masoquismo erógeno, masoquismo feminino e masoquismo moral.

A existência de tendências masoquistas é enigmática, desde o princípio, para a psicanálise. Partindo do suposto de que o princípio do prazer, dominante nos processos psíquicos, tem por objetivo evitar o desprazer e conseguir o prazer, o masoquismo torna-se algo incompreensível. "Se a dor e o desprazer podem já não ser advertências, mas objetivos em si mesmos, o princípio do prazer é paralisado, o guardião de nossa vida psíquica é como que narcotizado" (Freud, 1924b/2011, p. 185).

No entanto, sabe-se que a questão desenvolvida por Freud nesse texto fundamenta-se, sobretudo, na compreensão da relação do princípio do prazer com as pulsões de vida e de morte e não na recusa do princípio do prazer como guardião da vida. Se, de um lado, como expressão de um masoquismo erógeno que se encontra na base das outras duas manifestações masoquistas, feminino e moral, o masoquismo representa-se como condição para uma excitação sexual, de outro lado, o fato de que possa tornar-se um objetivo em si mesmo, de 
modo que o sofrimento torne-se a condição para o prazer, revela uma atuação da pulsão de morte independente de Eros.

Em Três Ensaios Sobre a Teoria da Sexualidade, a excitação sexual é definida por Freud (1905a/1974) como efeito secundário em uma gama de processos internos, quando a intensidade (excitabilidade) ultrapassa determinados limites quantitativos. A excitabilidade libidinal promove uma experiência de tensão que acompanha a dor e o desprazer, mas pode significar uma condição de elevação do prazer com a descarga da tensão represada. Desse modo, a experiência de prazer pressupõe uma elevação da excitabilidade pulsional e não apenas o rebaixamento imediato da tensão.

A libido encontra nos seres vivos (multicelulares) o instinto de morte ou destruição que neles vigora, que busca desintegrar este ser e conduzir cada um dos organismos elementares ao estado de inorgânica estabilidade (ainda que esta possa ser apenas relativa). Ela tem a tarefa de fazer inócuo esse instinto destruidor, e a cumpre desviando-o em boa parte - e logo com ajuda de um sistema orgânico particular, a musculatura - para fora, para os objetos do mundo exterior. Então ele se chamaria instinto de destruição, instinto de apoderamento, vontade de poder. Uma parte desse instinto é colocada diretamente a serviço da função sexual, na qual tem um importante papel. É o sadismo propriamente dito. Uma outra parte não realiza essa transposição para fora, permanece no organismo e, com ajuda da mencionada excitação sexual concomitante, torna-se ligada libidinalmente; nela devemos reconhecer o masoquismo original, erógeno (Freud, 1924b/2011, p. 191).

O masoquismo erógeno seria então, para Freud (1924b/2011), parte da pulsão de morte que permanece no Eu e que, agregada à libido, é responsável pela excitação sexual que possibilita um adiamento do princípio do prazer, possibilitando ao Eu novas ligações em busca da descarga libidinal, entretanto, postergada. Eros, ao introduzir no Eu, pela via da sexualidade, novas tensões, impulsiona à criação de novas formas de ligação à libido, mas também um adiamento ou suspensão da descarga libidinal, que pode ser significada pelo Eu como prazer. Todavia, quando não se consuma uma mescla pulsional originária entre a libido 
do Eu e a sexualidade, responsável por aliar o Eu ao princípio do prazer, imprimindo uma modificação no princípio do Nirvana, essa excitabilidade pode ser significada como ameaçadora, visto não vir acompanhada da possibilidade de representação, suspensão e adiamento da experiência.

Para Freud (1924b/2011), o sadismo primordial, que consiste em transpor para o objeto a pulsão de morte, seria idêntico ao masoquismo. Contudo, o masoquismo permanece no interior como um resíduo da pulsão de morte da qual o Eu não se pode desfazer, tornandose um componente da libido, embora preservando-se, mas também pulsão de morte nos limites do próprio Eu. Essa dupla face do masoquismo erógeno o torna originário na estruturação psíquica e necessário ao Eu. Este, através dessa experiência, pode dominar, em certa medida, a pulsão de morte, submetendo-se a ela sem, todavia, a ela sucumbir. O masoquismo erógeno seria, então, "testemunha e sobrevivência daquela fase de formação que sucedeu o amálgama, tão importante para a vida, de Eros e instinto de morte" (Freud, 1924b/2011, p. 192).

Viu-se que Freud caracterizou três modos de masoquismo, sendo o masoquismo feminino e o masoquismo moral, por ele também definidos, derivados do masoquismo erógeno originário. O masoquismo feminino é definido como o menos enigmático. O material que Freud dispõe para a sua análise são as fantasias de pessoas masoquistas que resultam no ato masturbatório ou representam em si mesmas a satisfação sexual. Embora retrate nesse texto os desempenhos reais dos pervertidos masoquistas, como análogos às suas fantasias, como fim em si ou como meio de induzir e levar ao ato sexual, ele associa o masoquismo feminino também às fantasias masoquistas que sofreram uma elaboração maior.

De qualquer modo, o que está em causa é a realização das fantasias em forma de um jogo em que o conteúdo manifesto é a destrutividade, experienciada pelo próprio sujeito como forma de obter a satisfação sexual. "O masoquista deseja ser tratado como uma criança 
pequena, desamparada e dependente, mas especialmente como uma criança malcomportada" (Freud, 1924b/2011, p.189). Nas fantasias que sofreram uma elaboração particularmente rica, “é fácil perceber que elas põem o indivíduo numa situação caracteristicamente feminina, isto é, “significam ser castrados, ser possuídos ou dar à luz" (1924b/2011, p. 189). Sobrepõem-se ao masoquismo feminino também as camadas das características infantis. Além disso, essa forma de masoquismo e o masoquismo moral têm por base sobre que se estruturam o masoquismo erógeno, que partilha de todas as fases de desenvolvimento da libido.

O masoquismo moral, diferentemente das outras formas, expressa uma atenuação de sua relação com o que se reconhece como sexualidade, embora não a ruptura entre essa forma de comportamento e o erotismo. Está em jogo, no masoquismo moral, o sofrimento em si mesmo, independentemente se é infligido pela pessoa amada ou por qualquer outra pessoa, podendo ser causado também por circunstâncias impessoais. "O verdadeiro masoquista sempre oferece a face quando vê perspectiva de receber uma bofetada" (Freud, 1924b/2011, p. 194). A explicação para esse comportamento seria o abandono da libido do objeto e o fortalecimento do impulso de destruição voltado para dentro.

Não ficaremos surpresos de ouvir que, em determinadas circunstâncias, o sadismo ou instinto de destruição voltado para fora, projetado, pode ser novamente introjetado, voltado para dentro, desse modo regredindo à sua situação anterior. Então ele resulta no masoquismo secundário, que se junta àquele original (Freud, 1924b/2011, p. 193).

A conduta dos masoquistas morais no tratamento e na vida causa a impressão de uma inibição moral excessiva. Acham-se "sob o domínio de uma consciência particularmente sensível, embora não estejam cônscios dessa hipermoral” (Freud, 1924b/2011, p. 199). Freud ainda aborda, no texto em questão, a relação existente entre a continuação inconsciente da moralidade expressa pelo sentimento de culpa inconsciente e o masoquismo moral. Existe 
diferença entre o sentimento de culpa inconsciente e a moralidade inconsciente, muito embora o relevo dado por Freud ao sadismo do Supereu demonstre que a excessiva consciência moral, que atua de forma inconsciente, seja complementar ao masoquismo do Eu. Ambos se juntam e produzem as mesmas consequências.

Nossa confusão inicial pode ser desculpada, pois em ambos os casos trata-se de uma relação entre o Eu e o Super-eu, ou poderes a estes equivalente; nas duas vezes lidamos com uma necessidade que é satisfeita mediante o castigo e o sofrimento. Não será um detalhe irrelevante que o sadismo do Super-Eu se torne gritantemente cruel, em geral, enquanto a tendência masoquista do Eu permaneça quase sempre oculta ao indivíduo e tenha de ser inferida do seu comportamento (Freud, 1924 b/2011, p. 199).

A inconsciência no masoquismo moral expressa-se na relação entre o comportamento do masoquista e suas fantasias sexuais. Este apresenta, frequentemente, em suas fantasias, o desejo de ser surrado pelo pai. Trata-se de uma deformação regressiva do desejo de ter uma relação sexual passiva com o pai (feminina), de forma que a consciência e a moralidade surgem em decorrência do complexo de Édipo. Sabe-se que o complexo de Édipo, ainda que leve, através da formação do Supereu, à internalização dos componentes libidinais destrutivos, não pode levar diretamente a uma intensificação do masoquismo. Se o Supereu resulta da internalização do representante parental no Eu e resulta no sentimento de culpa que expressa a tensão entre o Eu e o Supereu, sabe-se também que o sentimento de culpa resultante dessa tensão é diferente daquele que resulta no masoquismo moral.

Portanto, vale distinguir o sentimento de culpa, resultante dessa tensão entre o Eu e o Supereu, do comportamento masoquista. Se o sentimento de culpa deriva de uma impossibilidade do Eu de conciliar os interesses do Id e do Supereu, resultando dessa relação um mal-estar, sabe-se que não necessariamente o sentimento de culpa expressa-se como um comportamento masoquista, devendo haver outros elementos que incidem nessa atuação 
regressiva do desejo de ter uma relação sexual passiva com o pai, característica do comportamento masoquista.

Deve haver, portanto, outros elementos que levam à intensificação dessa relação complementar entre o sadismo e o masoquismo. Sabe-se que, quanto maior a renúncia à agressão maior a elevação da consciência moral e da moralidade. Freud afirma que, ao contrário do que se costuma pensar, não é a moralidade o elemento primário, tampouco a renúncia pulsional, sua consequência. "A primeira renúncia pulsional é forçada por poderes externos, e apenas então ela cria a moralidade, que se expressa na consciência e exige nova renúncia instintual” (Freud, 1924b/2011, p. 202).

Entende-se que, quando a pulsão de morte da qual o masoquismo procede, originariamente representado em sua mistura a Eros, retorna do mundo externo ao $\mathrm{Eu}$, associando-se ao masoquismo originário e escapando à predominância dos investimentos de Eros, a pulsão de morte pode expressar seu caráter silencioso e perigoso, sem abdicar, entretanto, da satisfação erótica. A relação entre a consciência e a moralidade no masoquismo moral evidencia essa relação.

Consciência e moralidade surgiram com a superação, a dessexualização do complexo de Édipo; com o masoquismo moral, a moralidade é novamente sexualizada, o complexo de Édipo é revitalizado, abre-se o caminho para regredir da moralidade ao complexo de Édipo. Isto não beneficia nem a moral nem o indivíduo. É verdade que este pode haver conservado, junto ao seu masoquismo, toda a sua moralidade ou um certo grau dela, mas boa parte de sua consciência [moral] também pode ter desaparecido graças ao masoquismo. (Freud, 1924b/2011, p.200).

A inconsciência no masoquismo moral expressa que, ao tornar a moralidade sexualizada como forma regressiva de preservar a satisfação libidinal advinda da relação edípica, a moralidade se torna um substituto da consciência. Desse modo, quanto maior a moral representada pelo Supereu maior a necessidade de renúncia à satisfação sexual. A 
renúncia sexual, possivelmente resultante de uma insuficiente sublimação e identificação, cobra seu preço a partir de uma regressão libidinal. A destrutividade do Supereu reforçada por um masoquismo originário encontra um substituto sexual para sua renúncia na moralidade da consciência.

A explicitação do masoquismo erógeno original e também de seus derivados teve por finalidade apontar, neste capítulo, a importância da mescla pulsional entre Eros e pulsão de morte no que diz respeito à estruturação da vida psíquica. Além disso, a partir da discussão sobre o masoquismo, apontar para os desdobramentos de uma disjunção pulsional que pode resultar de uma regressão da libido ao Eu, que ocorre, entre outras afecções, também na melancolia. Se a constituição do Supereu é condição da vida psíquica, ela é, ao mesmo tempo, o que impede que parte da pulsão de morte seja desviada para o mundo externo. Esse parece ser o risco da disjunção entre Eros e pulsão de morte.

A melancolia revelou-se uma afecção fronteiriça que coloca em cena, de forma singular, a ambivalência primordial entre amor e ódio. A impossibilidade de distinção de um objeto para o Eu faz com este, na melancolia, se torne impossibilitado de fornecer outro destino à pulsão de morte que não seja o próprio Eu. Numa união entre a severa moralidade e o inconsciente comportamento masoquista, o melancólico encontra uma brecha para o amor, ali onde ele não pode mais aquiescer-se com a vida. 


\section{CAPÍTULO 2: IDENTIFICAÇÃO E FORMAÇÃO DO SUPEREU}

\subsection{O complexo de Édipo e o complexo de castração: as bases do Supereu}

O estudo sobre a identificação é fundamental por descortinar no psiquismo a função da instância psíquica estruturada sobre sua base. A caracterização do Supereu foi introduzida neste trabalho a partir da noção de ideal do Eu, apresentada também como um desdobramento do narcisismo. O Supereu tem como função, além da formação de um ideal, a autoobservação e a consciência moral. Além disso, exerce sua influência no processo de recalque.

Dissemos que ele é o verdadeiro herdeiro do narcisismo original em que o ego infantil desfrutava de auto-suficiência; gradualmente reúne, das influências do meio ambiente, as exigências que este impõe ao ego, das quais este não pode sempre estar à altura; de maneira que um homem, quando não pode estar satisfeito com seu próprio ego, tem, no entanto, possibilidade de encontrar satisfação no ideal do ego que se diferenciou do ego (Freud, 1921a/1974, p. 138).

O complexo de Édipo, do qual o Supereu é herdeiro, é um tempo fundamental no desenvolvimento da criança. A formação do Supereu pressupõe a identificação a objetos de investimento que possam representar, em parte, a continuidade de uma satisfação experimentada pelo Eu como objeto primitivo de investimento. Entretanto, a constituição dessa instância psíquica, precisamente pela continuidade que ela apresenta com os primeiros investimentos objetais abandonados, significa também para o Eu restrições e impedimentos.

A identificação a um objeto tomado como modelo leva à internalização das figuras parentais para as quais, outrora, ambivalentemente, eram dirigidos o amor e a hostilidade. A dissolução do complexo de Édipo envolve um modo de identificação parcial aos objetos tomados como modelo para o Eu de forma que este, ameaçado pela castração que põe em risco sua integridade narcísica, identifica-se a um dos progenitores. 
O amor da criança por ambos os progenitores num período inicial da vida é ainda indiscernível quanto ao objeto das pulsões eróticas e das pulsões afetuosas (de fim inibido). Esse período, no qual a criança obtém da mãe não apenas a satisfação advinda da alimentação, mas também a proteção e os cuidados com o corpo, faz da mãe o primeiro sedutor da criança que, com esses cuidados, é erotizada. A criança ama eroticamente a quem lhe garante satisfação, proteção e autopreservação e não distingue completamente entre a natureza da satisfação propiciada por ambos os progenitores, embora possa distinguir um objeto para o Eu ainda que não necessariamente o Eu do objeto.

Por volta dos dois ou três anos de idade, a criança ingressa na fase fálica de seu desenvolvimento libidinal e vivencia sensações prazerosas em seus genitais a partir da sua estimulação. Nesse período, que caracteriza o ingresso da criança na fase fálica, o menino enxerga na mãe o objeto de seus desejos e tenta seduzi-la. "Quer possuí-la fisicamente, das maneiras que adivinhou de suas observações e intuições sobre a vida sexual, e tenta seduzi-la mostrando-lhe o órgão masculino que está orgulhoso de possuir" (Freud, 1938a/1974, p. 217). O pai, até então modelo invejado para o menino pela sua força física e pela autoridade que toda criança nele investe como figura onipotente, torna-se então um rival, do qual, por vezes, a criança gostaria de livrar-se.

A ameaça à castração que se segue à configuração edipiana advém dessa relação, na qual a criança vivencia constantes impedimentos e restrições dirigidas ao seu comportamento sexual. A manipulação do seu órgão genital lhe é proibida das mais diferentes formas e, ainda que o menino não abdique dessas fantasias masturbatórias com a ameaça da castração, sabe-se que ele abdica de suas atividades masturbatórias na iminência de preservar seu órgão sexual e, portanto, sua integridade narcísica.

Via de regra, a masculinidade da criança é incapaz de resistir a este primeiro choque. A fim de preservar seu órgão sexual, ele renuncia à posse da mãe de modo mais ou menos completo; sua vida sexual com 
frequência fica permanentemente dificultada pela proibição. Se um forte componente feminino como tal, tal como o chamamos, se acha presente nele, a força deste é aumentada por esta intimidação de sua masculinidade. Ele cai numa atitude passiva para com o pai, tal como a que atribui à mãe (Freud, 1938a/1974, p. 219).

O complexo de castração não se desenvolve, portanto, de forma simples, visto envolver o abandono de determinadas atividades que o menino observa como prazerosas, embora ameaçadoras, mas também a permanência de fantasias edípicas que se mantêm atuantes no psiquismo. Essas fantasias são intensificadas à medida que se tornam a única forma de satisfação sexual restante. Em suas fantasias, permanece identificando-se ao pai, embora possa identificar-se, simultaneamente e por vezes, com a mãe.

Essas fantasias abrem caminho no Eu para uma série de derivados e produtos modificados que ali serão estabelecidos, desempenhando um papel na formação do caráter. As relações edipianas tantas vezes sobrevivem de forma ambígua, deixando seus resquícios, embora, de maneira geral, o menino tenha como marco de sua dissolução edípica a identificação com o pai e a renúncia à mãe como objeto sexual.

A masculinidade do menino se retrai, por assim dizer, numa atitude desafiadora em relação ao pai, a qual dominará o seu comportamento posterior, na sociedade humana, de maneira compulsiva. Um resíduo de sua fixação erótica na mãe com frequência subsiste sob a forma de uma dependência excessiva dela, e isto persiste como uma espécie de servidão às mulheres (Freud, 1938a/1974, p. 219).

No entanto, mesmo deixando seus resquícios, o menino, frequentemente submetido a um recalque enérgico, renuncia ao amor pela mãe na perspectiva de permanecer sendo amado por ela. Afinal, não ser amado pela mãe colocaria em causa também o risco de ser entregue ao pai para a castração.

Freud (1938a/1974) apresenta diferenças sobre os efeitos do complexo de castração nas meninas. Nelas, seus efeitos são mais uniformes, embora não menos profundos. Se, no 
menino, o reconhecimento da castração impele à saída do complexo edipiano, na menina, a entrada no complexo edipiano é concomitante à constatação da castração como um fato. As possibilidades de identificação que dessa fase decorrem também não são únicas.

A menina reage ao temor da castração manifestando sua inveja dos meninos à posse do pênis. Seu receio é o de não ser portadora de um pênis. Sabe-se que, se a menina persiste em seu desejo masculino, poderá desenvolver, em casos extremos, a homossexualidade manifesta ou apresentar traços marcadamente masculinos em suas escolhas na vida futura. Outro caminho também possível na relação entre o complexo edipiano e o complexo de castração na menina é o abandono de seu objeto primitivo de amor, a mãe, e sua substituição pelo pai, portador do pênis desejado. Nesse caso, pode ocorrer de, identificando-se com a mãe, seu objeto de amor abandonado, esta se tornar objeto de sua rivalidade tanto pelo amor do pai como por responsabilizá-la pela ausência de um pênis.

A relação entre a menina e o pai culmina na substituição do desejo pelo pênis do pai à sua disposição, pelo filho gerado pelo pai e, posteriormente, pelo desejo de um bebê. Essa relação demonstra a atitude edipiana feminina, na medida em que ocorre uma inversão do objeto de amor, da mãe para o pai, que tem como elemento propulsionador a falta do pênis, que impele a menina ao seu complexo de Édipo.

Nesse caso, escolherá o marido pelas características paternas dele e estará pronta a reconhecer a sua autoridade. O seu anseio de possuir um pênis, que é, na realidade, insaciável, pode encontrar satisfação se ela for bem sucedida em completar o seu amor pelo órgão estendendoo ao portador do órgão, tal como aconteceu anteriormente, quando progrediu do seio da mãe para a mãe como uma pessoa completa (Freud, 1938a/1974, p. 223).

O complexo de Édipo como precursor da formação do Supereu é uma fase importante do desenvolvimento sexual da criança. A formação do Supereu coloca em cena, de certo modo, os direcionamentos dos investimentos objetais e a apropriação desses investimentos 
pelo Eu. O anseio de satisfação sexual, característica da relação edípica, sucumbe ao complexo de castração, levando ao afastamento do Eu do complexo de Édipo e à entrada da criança na fase de latência, em que os interesses sexuais permanecem desviados para outros interesses. Freud (1924c/2011) refere-se ao recalque para caracterizar o afastamento do complexo de Édipo e o direcionamento do Eu para outras possibilidades de investimento.

O recalque da libido sexual, que a torna, em parte, de fim inibido, transformando parte da pulsão erótica em sentimentos afetuosos, ocorre, portanto, quando a criança se depara com a ameaça da castração e renuncia ao investimento sexual em seu objeto de amor, substituindoo, em parte, pela identificação ao objeto tomado como modelo. Essa renúncia caracteriza a saída do complexo de Édipo e representa a possibilidade de a criança identificar-se a um dos progenitores, sublimando parte da libido sexual, como forma de autopreservar-se e fortalecerse em seu Eu, oferecendo-se como objeto de amor ao Id e participando de seus investimentos objetais.

\begin{abstract}
A autoridade do pai ou dos pais, introjetada no $\mathrm{Eu}$, forma ali o âmago do Supereu, que toma ao pai a severidade, perpetua a proibição do incesto e assim garante o Eu contra o retorno do investimento libidinal de objeto. As tendências libidinais próprias do complexo de Édipo são dessexualizadas e sublimadas em parte, o que provavelmente ocorre em toda transformação em identificação, em parte inibidas na meta e mudadas em impulsos ternos. Todo o processo, por um lado, salvou o genital, afastou dele o perigo da perda, e, por outro lado, paralisou-o, suspendeu sua função. Com ele tem início o período de latência, que interrompe o desenvolvimento sexual da criança (Freud, 1924c/2011, p. 208-209).
\end{abstract}

A relação com os pais modifica-se radicalmente. "A criança ainda permanece ligada a eles, mas por pulsões que devem ser descritas como 'inibidas em seu objetivo'. As emoções que daí passa a sentir por esse objeto de seu amor são caracterizadas como 'afetuosas'” (Freud, 1921a/1974, p.141). O Eu abdica do objeto sexual para garantir sua integridade (unidade) corpórea. A constituição do Supereu envolve a modificação de parte do Eu a partir 
da identificação, mas também a conservação do narcisismo a partir da formação do ideal do Eu.

Contudo, Freud (1924c/2011) constata que a derrocada do complexo edipiano diante da ameaça de castração, quando realizada efetivamente, leva não somente ao recalque, mas à abolição e destruição do complexo. Ele problematiza com essa questão a linha divisória entre o normal e o patológico, nunca inteiramente nítida. "Se o Eu realmente não alcançou muito mais que uma repressão do complexo, este persiste de modo inconsciente no Id, e manifestará depois a sua ação patogênica" (Freud, 1924c/2011 c, p. 210). Desse modo, o fato de que o complexo de Édipo naufrague a partir da castração não significa que a questão referente aos investimentos objetais abandonados esteja liquidada.

O processo de identificação ocorrido no complexo de Édipo deixa como herança a formação do Supereu como uma instância constitutiva do Eu. Na melancolia, a formação do Supereu, entretanto, como um legado derivado do naufrágio do complexo edipiano, envolve processos outros que demonstram a ação patogênica resultante da não resolução dos processos edípicos e da dificuldade do melancólico de colocar-se frente a frente com a castração. Se, por um lado, é possível dizer que a não resolução do complexo edípico mantém os investimentos edipianos afastados do Eu, manifestando sua ação patogênica na manifestação do sintoma, por outro, a ação patogênica pode manifestar-se não exclusivamente no sintoma, mas também na inibição da melancolia.

O reconhecimento do complexo de castração é elemento determinante para que o Eu renuncie a uma satisfação libidinal amorosa. No limite, a renúncia do Eu ao objeto de amor pressupõe que o desprazer decorrente da satisfação sexual seja maior do que o prazer derivado da satisfação renunciada. O que significa dizer que a ameaça de castração é determinante no que concerne aos rumos da identificação. A criança identifica-se ao progenitor do sexo oposto 
no intuito de autoconservar-se e, ao fazê-lo, busca, através do ideal do Eu, preservar sua satisfação.

Ocorre que, na melancolia, a identificação adquire outra função. Inversamente do que ocorre na formação dos sintomas nas neuroses de transferência, o Eu não renuncia ao objeto perdido senão que se identifica a ele no intuito de garantir uma satisfação narcísica não alterada em sua meta sexual. O desdobramento dessa identificação é que o objeto cumpre a função de garantir ao Eu uma satisfação não parcial, mas total. Nesse sentido, a libido não alterada em sua meta busca no objeto a garantia de uma satisfação narcísica, de modo que o objeto é colocado no lugar de sujeito e não de objeto do Eu.

Tornando-se a satisfação libidinal do Eu condicionada ao objeto no Eu, não pode o Eu suportar a ameaça de castração, na medida em que esta envolve a ameaça não exclusiva à satisfação narcísica do Eu, mas ao próprio Eu e à sua autoconservação. Nesse sentido, o reconhecimento da castração seria algo mais desprazeroso ao melancólico do que o recuo diante dela. De alguma forma, esse recuo do melancólico diante da castração, tão característico de sua impossibilidade de suportar a frustração, encontra-se na origem de sua impossibilidade de renunciar ao objeto perdido.

\subsection{O Supereu - uma parte mais ou menos integrada ao Eu - entre a libido sublimada e a destrutividade}

O Supereu constitui-se a partir do processo de identificação, representante interno da realidade e das transformações sofridas pelo Eu. Se o seu legado é o recalque à satisfação sexual dirigida ao objeto, não há, todavia, no compromisso entre o Eu e o Supereu, a barganha de abdicar por completo da satisfação sexual e tampouco do ideal sexual de autopreservação do Eu. Entretanto, há a barganha de sua substituição, ou seja, de uma alteração não da 
finalidade sexual, mas da forma através da qual se obtém essa finalidade, envolvendo a suspensão sexual temporária de parte da libido, da qual provem a força do Eu empregada no processo de identificação ao objeto tomado como modelo.

\begin{abstract}
Abandonando o complexo de Édipo, uma criança deve, conforme podemos ver, renunciar às intensas catexias objetais que depositou em seus pais, e é como compensação por essa perda de objetos que existe uma intensificação tão grande das identificações com seus pais, as quais provavelmente há muito estiveram presentes em seu ego (Freud, 1933a/1974, p. 83).
\end{abstract}

A dissolução do complexo de Édipo coloca importantes questões quanto à formação do Supereu e o destino das vicissitudes pulsionais. O complexo de Édipo é um processo que envolve várias possibilidades de identificação ao objeto tomado como modelo e diferentes vicissitudes pulsionais que dele decorrem. “(...) essas relações são tão complexas que se torna necessário descrevê-las com mais vagar. Dois fatores respondem por essa complexidade: a natureza triangular da situação edípica e a bissexualidade constitucional do indivíduo" (Freud, 1923a/2011, p. 39).

Freud, ao definir o complexo de Édipo, refere-se ao complexo normal positivo e negativo invertido. O positivo seria a identificação do menino com o pai enquanto objeto tomado como modelo para o Eu e a renúncia à catexia objetal em direção à mãe. Isso preservaria, a partir do Édipo, a relação de objeto com o modelo da mãe e a identificação com o pai como modelo.

Entretanto, Freud (1923a/2011) acrescenta que, devido à bissexualidade constitutiva dos homens, o complexo de Édipo é sempre positivo normal e negativo invertido. Ou seja, via de regra, se encontra em questão tanto a identificação materna como a identificação paterna numa mesma pessoa, ao mesmo tempo em que a escolha objetal envolve a figura materna e paterna. Destarte, a renúncia à parte da catexia objetal dirigida a um dos progenitores tomado 
como objeto sexual é realizada e a libido retirada dessa relação é investida na identificação com o outro progenitor tomado como modelo para o Eu. O menino tem a mãe como objeto sexual e o pai como objeto de identificação. Entretanto, podem sobreviver, lado a lado nessa experiência psíquica, o amor pelo pai enquanto objeto sexual e a identificação com a mãe tomada como modelo.

$\mathrm{Na}$ dissolução do complexo de Édipo, as quatro tendências nele existentes se agruparão de forma tal que delas resultará uma identificação com o pai e uma identificação com a mãe, a identificação com o pai mantendo o objeto materno do complexo positivo e ao mesmo tempo substituindo o objeto paterno do complexo contrário; as coisas sucederão de forma análoga na identificação com a mãe. O peso maior ou menor das duas disposições sexuais será refletido na diferente intensidade das duas identificações (Freud, 1923a/2011, p. 42).

O desenlace da situação edípica numa identificação com o pai ou com a mãe depende, segundo Freud (1923a/2011), da relativa força das duas disposições sexuais, além do fato de que a bissexualidade original da criança configura uma atitude ambivalente em relação aos progenitores desde o início. O menino, por exemplo, não somente tem pelo pai uma atitude ambivalente e uma escolha objetal terna pela mãe, mas também uma atitude feminina para com o pai e, de forma correspondente, uma atitude hostil dirigida à mãe. "Essa interferência da bissexualidade torna muito difícil compreender as primitivas identificações e escolhas objetais, e ainda mais difícil descrevê-las de modo inteligível” (Freud, 1923a/2011, p. 41).

De qualquer modo, o legado da fase sexual dominada pelo complexo de Édipo "é um precipitado no Eu, consistindo no estabelecimento dessas duas identificações, de algum modo ajustadas uma à outra. Essa alteração do Eu conserva a sua posição especial, surgindo ante o conteúdo restante do Eu como ideal do Eu ou Super-eu” (Freud, 1923a/2011, p. 42). O pai, tomado como modelo, interdita o acesso ao objeto de desejo ainda que abra o caminho para o desejo. 
Essa interpretação decorre do fato de que a identificação exige uma substituição para a renúncia ao objeto sexual e também uma suspensão da finalidade sexual que se liga à formação no Eu de uma reserva narcísica, necessária à possibilidade de novos investimentos. Metaforicamente, ser como o pai significa amar conforme o modelo do pai. O limite dessa identificação é que ser como o pai não possibilita o acesso ao objeto de desejo, mas ao objeto como o que constitui o sujeito de desejo, para além de sua condição fundante e alienante, de parte do desejo do outro.

Como herdeiro do Édipo, o Supereu é marcado pela lei e pela cultura. É expressão do modelo parental que incide sobre o ideal de autopreservação derivado do narcisismo. Se o Supereu é uma instância que representa o modelo do pai tal qual representado pelo sujeito no que lhe é referência e ideal, sempre idealizado, é também marca da renúncia ao objeto sexual que, internamente, foi substituído pela força do pai, tomada de empréstimo pelo Eu e da qual provem sua força.

Quanto mais os objetos de identificação do $\mathrm{Eu}$ representem a possibilidade de reconhecimento em suas catexias objetais abandonadas menor a necessidade do Supereu investir grande esforço no recalcamento. Esse seria um tipo de catexia erótica a que Freud (1914a/2010) denomina ego-sintônica.

$\mathrm{O}$ desenvolvimento do Eu consiste num afastamento do narcisismo primário e gera um intenso esforço para reconquistá-lo. Tal distanciamento ocorre através do deslocamento da libido para um ideal do Eu imposto de fora, e a satisfação, através do cumprimento desse ideal. Ao mesmo tempo, o Eu enviou os investimentos libidinais de objeto. Ele se empobrece em favor desses investimentos, tal como do ideal do $\mathrm{Eu}$, e novamente se enriquece mediante as satisfações ligadas a objetos, assim como pelo cumprimento do ideal (Freud, 1914a/2010, p. 48).

A constituição do Supereu resulta, portanto, na possibilidade do manejo da ambivalência interna entre o amor e ódio. Segundo Freud (1923 a/2011), a dessexualização 
pulsional (retirada da catexia erótica do objeto sexual) ocorrida na identificação deixa também como desdobramento uma disjunção das pulsões que atuavam de forma conjunta até então. Se a pulsão erótica é a que conduz a pulsão de morte para o mundo externo, uma vez dessexualizada a libido, ela perde sua força em conduzi-la para o mundo externo. A condição para que a pulsão de morte possa mesclar-se novamente à pulsão erótica é que o Eu possa participar, com a formação do ideal do Eu, dos investimentos objetais do Id. O amor e o ódio são componentes que representam a relação entre Eros e pulsão de morte e atuam de forma conjunta entre as instâncias do Eu e o mundo externo.

O desvio dos investimentos objetais do Id, que são tomados de empréstimo pelo Eu a partir da identificação, em que este se apropria de parte da libido objetal transformando-a em libido do Eu, constitui um momento de parceria entre Eros e o Eu. Afinal, esse desvio perturba o fluxo direto da libido em direção à descarga, introduzindo no Eu novas tensões e impedindo o rebaixamento completo dessas.

(...) o Eu lida com os primeiros investimentos objetais do Id, e sem dúvida também com os posteriores, acolhendo em si a libido deles e ligando-a à mudança do Eu produzida pela identificação. A essa transformação em libido do Eu vincula-se naturalmente um abandono dos objetivos sexuais, uma dessexualização. De todo modo, assim compreendemos um importante papel do Eu em sua relação com Eros (Freud, 1923a/2011, p. 57).

De outro lado, ao transformar-se em objeto de amor para o Id, apoderando-se da libido dos investimentos objetais e dessexualizando parte dela, o Eu trabalha também de encontro às intenções de Eros, colocando-se a serviço da pulsão de morte, que visa o desligamento da libido dos objetos. Um dos legados deixados pela formação do Supereu como instância interna é a pulsão de morte voltada para dentro. Com a constituição do Supereu, parte da hostilidade outrora projetada para o mundo externo retorna para o mundo interno e, se 
desligada das pulsões eróticas, perde grande parte de sua potencialidade para dirigir-se novamente para o mundo externo.

Freud (1923a/2011) afirma ser necessário distinguir duas espécies de pulsões: Eros e pulsão de morte. A primeira é a mais visível e acessível ao conhecimento, compreendendo tanto a libido sexual desinibida como os impulsos sublimados e inibidos em sua meta. Além disso, abarca as pulsões de autopreservação e busca agregar amplamente a substância viva dispersa, tornando a vida mais complexa; já a pulsão de morte tem como tarefa reconduzir os organismos vivos a um estado inanimado.

Ambas atuam conjuntamente na medida em que têm por função a conservação da vida no sentido mais estrito, empenhando-se em restabelecer um estado perturbado pelo surgimento da vida. "Este surgimento seria, então, a causa da continuação da vida e, ao mesmo tempo, da aspiração pela morte, a própria vida sendo luta e compromisso entre essas duas tendências" (Freud, 1923a/2011, p. 51).

A dessexualização pulsional, destarte, se pode conduzir a uma transformação no âmbito da libido dirigida ao objeto, fortalecendo o Eu, pode também significar uma disjunção entre Eros e pulsão de morte, em que o componente erótico perde a força necessária para vincular a destrutividade a ele ligada. Esta apareceria, então, como impulso à agressão e à destruição, que se manifesta no caráter duro e imperioso do Supereu. "O Super-eu nasceu [nasce] de uma identificação com o modelo do pai. Toda identificação assim tem o caráter de uma dessexualização ou sublimação. Parece que também ocorre, numa tal transformação, uma disjunção instintual” (Freud. 1923a/2011, p. 68).

Neste sentido, sempre haverá uma tensão entre o Eu e o Supereu, visto que o Eu, ao transformar parte do investimento objetal em libido do Eu a partir da identificação, apropriase também da agressão antes dirigida a este mesmo objeto. O caráter hostil do Supereu representa, em larga medida, a agressividade dirigida ao objeto, que retorna a partir da 
constituição do Supereu para seu lugar de origem. Dessa maneira, o Supereu envolve não somente parte da libido desviada do objeto sexual e investida na identificação como também parte da agressividade mesclada à libido.

Se as duas pulsões atuam desde o princípio de forma conjunta, sabe-se que a pulsão de morte só pode ser percebida quando atua desligada de Eros. "Os perigosos instintos de morte são tratados de várias maneiras no indivíduo, em parte são tornados inofensivos pela mistura com componentes eróticos, em parte são desviados para fora como agressão, e em larga medida prosseguem desimpedidos o seu trabalho interior" (Freud, 1923a/2011, p. 67-68).

A tensão entre o Eu e o Supereu, sempre existente, expressa-se como sentimento de culpabilidade e pode ser compreendida como um mal-estar característico de uma não conciliação entre os investimentos libidinais do Eu e o Supereu (Freud, 1930a/1974). Essa tensão pode expressar-se no sujeito tanto como possibilidade que o mobiliza a constantes investimentos quanto como um imobilismo diante da vida. Representa a atuação conjunta e indissociável entre Eros e pulsão de morte. Todavia, sabe-se que a impossibilidade de sustentar o estado de tensão pode ocasionar diversas formas de defesa, que se manifestam de maneiras distintas e são elucidativas da relação que se estabeleceu entre o Eu e o Supereu.

A importância do Supereu em sua relação com o Eu é ressaltada por Freud em o Eu $e$ $o$ Id. Há duas formas através das quais o conteúdo do Id pode penetrar no Eu. Uma é direta e a outra por intermédio do ideal do Eu. É decisivo para algumas atividades psíquicas em qual desses dois caminhos elas ocorrem. O desenvolvimento do Eu pressupõe um caminho que vai “da percepção dos instintos ao domínio sobre eles, da obediência aos instintos à inibição deles. Nesta operação tem forte presença o ideal do Eu, que é, em parte, uma formação reativa aos processos instintuais do Id" (Freud, 1923a/2011, p. 70).

Portanto, o ideal do Eu exerce uma função importante no desenvolvimento do Eu. Ele introduz neste parte da agressividade dirigida ao mundo externo, mas também parte da libido 
retirada do objeto abandonado que, mesclada à agressividade, pode possibilitar ao Eu participar de outra porção dos investimentos objetais do Id, obtendo controle e satisfação sobre eles. O Eu, segundo Freud (1923a/2011), se fortalece a partir da identificação, da qual se forma o ideal do eu, podendo tornar-se, portanto, ativo em sua relação com as duas espécies de pulsão, a de vida e a de morte.

Com seu trabalho de identificação e sublimação presta ajuda aos instintos de morte na subjugação da libido, mas arrisca tornar-se objeto desses instintos e mesmo perecer. A fim de prestar esse auxílio, teve de encher-se ele próprio de libido; com isso torna-se representante de Eros, e quer então viver e ser amado (Freud, 1923a/2011, p. 71).

No entanto, ainda assim, sabe-se que esse é um processo de vida e morte em que o Eu configura-se submetido a uma tripla servidão, ameaçado por três perigos: o mundo exterior, a libido do Id e o rigor do Supereu. Freud (1923a/2011) acrescenta que, dessas três relações de dependência, a mais interessante talvez seja a relação estabelecida com o Supereu. O Eu é uma entidade fronteiriça, que anseia mediar o Id e o mundo, oferecendo-se ao Id como objeto libidinal e guiando para si a libido do Id. Procura, sempre que possível, estar em bom acordo com este, tornando-se, muitas vezes, adulador.

O Supereu é um legado do processo de identificação, decisivo na relação entre o Eu e os investimentos libidinais. A identificação consolida-se como a internalização dos objetos abandonados e integrados parcialmente ao Eu. Representa, portanto, a força e o preço pago pelo Eu para tornar-se mediador nessa relação entre o Id e o mundo externo, de modo a não se tornar imparcial na relação entre Eros e pulsão de morte. De outro lado, submetido a uma tripla servidão, o Eu constitui-se também como a sede da angústia (Freud, 1923a/2011).

Não podemos especificar o que o Eu teme nos perigos externos e no perigo da libido do Id; sabemos que é a dominação ou a destruição, mas analiticamente não se deixa apreender. $\mathrm{O}$ Eu segue, 
simplesmente, a admoestação do princípio do prazer. No entanto, é possível dizer o que se esconde atrás da angústia do Eu ante o Supereu, angústia da consciência moral. (Freud, 1923a/2011, p. 72)

Percebe-se, analiticamente, no que se refere à angústia do Eu diante dos perigos que o ameaçam, a angústia da consciência moral, que se manifesta nessa relação entre o Eu e o Supereu. É certo, segundo Freud (1923a/2011), que a angústia da consciência moral, assim como a angústia da morte, tão expressiva na melancolia, como será apresentado no próximo capítulo, podem ser apreendidas como atualização da angústia de castração.

Desse modo, com a formação do Supereu, o temor da castração apresenta-se como angústia da consciência moral. Sabe-se que o sentimento de culpa proveniente da tensão entre o Eu e o Supereu exerce um importante papel na neurose. Entretanto, é possível considerar que, em muitos casos e em casos severos, a angústia neurótica ordinária seja reforçada pelo desenvolvimento da angústia entre o Eu e o Supereu e, portanto, pela angústia da consciência moral.

Quanto à função do Eu, conclui-se que, estando ele submetido a uma tripla servidão, é ainda a instância capaz de, através do ideal do Eu, dominar e inibir o Id em sua exigência direta de satisfação sexual, sublimando partes da libido para si e seus fins. O Id, ao contrário, não tem meios de mostrar amor ou ódio ao $\mathrm{Eu}$, devendo, portanto, ser dominado pelo $\mathrm{Eu}$ através da formação do ideal do Eu.

O Id, ao qual retornamos por fim, não tem meios de mostrar amor ou ódio ao Eu. Não pode dizer o que quer; não constituiu uma vontade uniforme. Eros e instinto de morte lutam dentro dele; vimos com que meios uma dessas classes de instintos se defende da outra. Poderíamos imaginar que o Id se acha sob a dominação dos silenciosos, mas poderosos, instintos de morte, que querem ter paz e fazer calar Eros, o estraga sossegos, por instigação do princípio do prazer (Freud, 1923a/2011, p. 73-74). 


\subsection{A identificação e a função de síntese do ideal do Eu: as vicissitudes libidinais}

O estudo da melancolia realizado por Freud (1917a/2011) revela questões importantes quanto ao campo da identificação na psicanálise. Na melancolia, um objeto que fora perdido instala-se novamente dentro do Eu, configurando-se como uma "sombra do objeto perdido". Ou seja, uma catexia de objeto foi substituída pela identificação. Sabe-se que, em um momento primitivo do desenvolvimento da criança, a catexia objetal e a identificação são indistintas; também, apenas posteriormente, tornam-se processos separados, embora permaneçam ligados, em certa medida, em sua finalidade de satisfação.

Em Psicologia de Grupo e Análise do Ego, Freud (1921a/1974) define a identificação “como a mais remota expressão de um laço emocional com outra pessoa. Ela desempenha um papel na história primitiva do complexo de Édipo" (Freud, 1921a/1974, p. 133). Na mesma obra, refere-se à identificação como um derivado da primeira fase da organização da libido, a fase oral, que tem por característica a assimilação por ingestão do objeto prezado e ansiado.

Freud (1905a/1974) refere-se a essa fase da qual a identificação é um derivado como uma organização sexual pré-genital canibal, em que a atividade sexual está vinculada à ingestão de alimentos. "O objeto de ambas as atividades é o mesmo: o objetivo sexual consiste na incorporação do objeto - o protótipo de um processo que, sob a forma de identificação, deverá desempenhar mais tarde um importante papel psicológico" (Freud, 1905a/1974, p. 204).

Todavia, a condição para que o Eu ainda não constituído possa satisfazer-se sexualmente com o objeto incorporado, sendo a incorporação, a princípio, uma reação ao inevitável desprazer de uma elevação de tensão, é a de distinguir, nesse movimento, um objeto para o Eu a partir do qual ele pode reconhecer-se também como objeto de satisfação. Assim, também o Eu pode, posteriormente, constituir-se tendo por meta uma finalidade de 
preservação do prazer que não seja autodestrutiva. Entretanto, se a identificação não se constitui como um mecanismo que possibilita a distinção de um objeto para o Eu, pode acontecer também, como nota-se na melancolia, que a identificação se torne um sucedâneo para a catexia objetal abandonada, tornando-se o próprio objeto e não a libido objetal sublimada, um substituto para a satisfação do Eu.

A identificação, portanto, apesar de constituir-se como um derivado da fase em que a atividade sexual de satisfação não se distingue ainda do objeto sexual, é diferente da incorporação do objeto. Freud (1921a/1974) afirma que é fácil enunciar a diferença entre a identificação com o pai e a escolha deste como objeto e, a rigor, a identificação define-se como um esforço "por moldar o próprio ego de uma pessoa segundo o aspecto daquele que foi tomado como modelo" (Freud, 1921a/1974, p.134).

No primeiro caso, o pai é o que gostaríamos de ser; no segundo, o que gostaríamos de ter, ou seja, a distinção depende de o laço se ligar ao sujeito ou ao objeto do ego. O primeiro tipo de laço, portanto, já é possível antes que qualquer escolha sexual de objeto tenha sido feita. (Freud, 1921a/1974, p. 134).

No entanto, esse processo não pode ser simplificado. A identificação, tal como ocorre na estrutura do sintoma neurótico, é apresentada em suas diferentes formas de manifestação, evidenciando que não existe um único modelo a partir do qual o Eu se apropria de um aspecto do objeto. Freud (1921a/1974) refere-se ao sintoma de uma menina que, identificada à mãe, desenvolve o mesmo penoso sintoma que ela, uma tosse atormentadora. Segundo ele, a identificação pode provir do complexo de Édipo e expressar o amor objetal da menina pelo pai e a influência do sentimento de culpa por assumir o lugar da mãe em seu sintoma.

Ocorre que o sintoma pode também se desenvolver de modo a tomar como modelo de identificação a pessoa amada. Freud (1921a/1974) refere-se ao caso de Dora, que imitava a tosse do pai, expressando um modelo em que a identificação aparece no lugar da escolha de 
objeto, com a escolha regredindo para a identificação. Esses casos são frequentes, segundo Freud, quando os sintomas são construídos em condições em que há recalque e os mecanismos do inconsciente são dominantes. Nesse caso, o Eu assume as características do objeto.

O terceiro caso referente à formação de sintomas a partir da identificação tem como expressão um exemplo (Freud, 1921a/1974) em que uma moça de um internato, secretamente enamorada, recebe da pessoa a quem dirige seus sentimentos uma carta que lhe desperta ciúmes e reage a ela por uma crise histérica. Algumas amigas, conhecedoras da situação e movidas por um contágio mental, identificam-se à amiga e tomam para si a sua reação. Esse mecanismo de identificação fundamenta-se, segundo Freud, no desejo de colocar-se na mesma situação. Nesse caso, "a identificação por meio do sintoma tornou-se assim o sinal de um ponto de coincidência entre os dois egos, sinal que tem que ser mantido reprimido" (Freud, 1921a/1974, p.137). A identificação deixa fora de consideração qualquer relação de objeto com a pessoa que está sendo copiada.

Esses três exemplos de formação de sintomas ressaltam que a identificação é parcial e limitada, além de tomar de empréstimo um único traço isolado da pessoa objeto de identificação. Entretanto, há ainda (Freud, 1921a/1974) outras possibilidades que envolvem a identificação em ampla escala e não apenas a identificação parcial a um traço do objeto. Trata-se de um tipo de identificação que remolda o Eu em um dos seus mais importantes aspectos, seu caráter sexual, segundo o modelo do que até então constituíra o objeto. Freud afirma que, nesse caso, não se sabe se inteiramente se o "objeto em si mesmo é renunciado ou perdido" (Freud, 1921a/1974, p. 137), ou se é preservado no inconsciente.

A melancolia e o homossexualismo são apresentados por Freud (1921a/1974) como exemplos que evidenciam que a identificação envolve a introjeção no Eu do objeto renunciado ou perdido. Outro exemplo apresentado de introjeção do objeto no Eu é o de uma 
criança pesarosa pela perda de um gatinho e que se declara como sendo o próprio, comportando-se, por conseguinte, como o animal perdido.

Freud, ao definir a identificação em Psicologia de Grupo e Análise do Ego, afirma que o objeto foi perdido ou abandonado na identificação; “assim ele é novamente erigido dentro do ego e este efetua uma alteração parcial em si próprio, segundo o modelo do objeto perdido (Freud, 1921a/1974 a, p. 144). Há, portanto, uma alteração parcial do Eu. O Eu identifica-se ao objeto, assimilando traços que o alteram e modificam também sua meta de satisfação sexual, que se torna de fim inibido.

A identificação, portanto, é distinta da introjeção do objeto no Eu, na medida em que, nela, o objeto é transformado em um modelo para o Eu, que se enriquece com o objeto abandonado como objeto sexual. Trata-se de uma transformação da libido retirada do objeto e investida no Eu. A identificação pressupõe, portanto, a distinção de um objeto interno para o Eu, para que também o Eu possa distinguir-se do objeto. Contudo, sabe-se que a identificação da qual resulta o ideal do Eu é sempre singular e envolve uma série de possibilidades que apontam diferentes vicissitudes libidinais. São elas: "a reversão no contrário, o retorno em direção à própria pessoa, o recalque e a sublimação. (Freud, 1915a/2013, p. 35).

As características assumidas pelo ideal do Eu e a relação que ele mantém com o Eu evidenciam que, uma vez constituído, o ideal adquire a função de possibilitar uma elaboração psíquica interna ao Eu para a libido desviada do objeto sexual. Freud (1921a/1974) refere-se a algumas possibilidades de identificação que, embora não envolvam diretamente a introjeção do objeto no $\mathrm{Eu}$, como na melancolia, colocam em evidência destinos libidinais que expressam que a libido de fim inibido, desviada do objeto sexual e investida na formação do ideal do Eu, não necessariamente sofre uma alteração em sua natureza, embora promova uma alteração no Eu a partir do objeto internalizado. 
Sabe-se que o recalque é um mecanismo efetuado pelo Eu incitado pelo ideal do Eu e que compele à renúncia do Eu aos seus objetos sexuais. A função do recalque é estabelecer uma separação entre a satisfação sexual de fim inibido e a satisfação de fim não inibido. Essa separação não significa que as primitivas tendências "sensuais" sejam extintas. Ao contrário, elas permanecem preservadas no inconsciente, de modo que a corrente sexual original continua a existir, embora recalcada. Ademais, o recalque à libido dirigida ao objeto sexual é sempre parcial, de modo que outra parte da corrente sexual permanece exigindo satisfações mais diretas.

O ideal do Eu, uma vez constituído, reforça o recalque, embora possa também favorecer a sublimação de parte das pulsões de fim sexual, adquirindo a função de mediar a relação entre o Eu, as exigências dos investimentos objetais do Id e o mundo exterior. Em sua relação com o Eu, o ideal cumpre a finalidade de reforçar o recalque de parte da libido dirigida ao objeto sexual bem como auxiliá-lo na sublimação de outra parte, possibilitando ao Eu defender-se, ao diferenciar-se do objeto, dos investimentos diretos do Id. No período conhecido como período de latência, subsequente à fase fálica, há uma intensificação da identificação ao objeto tomado como modelo e um investimento libidinal do Eu em suas relações afetuosas e inibidas em sua finalidade sexual.

Com a chegada da puberdade e a força dos novos impulsos com objetivos diretamente sexuais, que se encontravam suspensos na fase de latência, alguns destinos para a libido sexual recalcada são possíveis. No primeiro deles, o adolescente, pela mediação do ideal do Eu, efetua certo grau de síntese entre o amor não sensual ou de fim inibido e o amor sensual ou de fim não inibido. Nesse caso, sua relação com seu objeto sexual decorrente da síntese explicita a interação entre a libido desinibida e a libido inibida em seu objetivo. Pode-se dizer que, estando a satisfação sexual em sintonia com a satisfação do Eu e do seu ideal, o Eu consegue satisfazer-se quanto ao seu ideal e na sua referência ao mundo externo. 
Outro caminho possível da puberdade é que a satisfação sexual desviada de seu objetivo sexual direto seja encontrada somente quando a corrente sexual de fim inibido (afetuosa) é isolada da corrente sexual de fim não inibido (sensual), de modo a não encontrarem uma síntese. "Um homem mostrará um entusiasmo sentimental por mulheres a quem respeita profundamente, mas não o excitam a atividades sexuais, e só será potente com outras mulheres a quem não 'ama', a quem pouco considera, ou mesmo despreza” (Freud, 1921a/1974, p.142).

Estabelece-se, nesse caso, uma separação maior entre os impulsos afetuosos representados pelo ideal do Eu e os impulsos sensuais recalcados, mantidos afastados do Eu. Há preponderância do mecanismo do recalque em detrimento da sublimação na constituição do ideal do Eu. A intensificação do recalque, se, de um lado, afasta a libido de fim inibido do Eu, de outro promove a idealização do objeto abandonado como meio de manter a satisfação sexual à distância do Eu.

Ao contrário do que aparenta, esse processo evidencia que a formação do ideal do Eu, nesse caso, embora explicite uma renúncia do Eu à parte da libido sexual, não é suficiente para promover uma alteração no Eu a partir da libido, de modo que ela é afastada do Eu retornando sob a forma de um idealizado ideal do Eu sempre distante das possibilidades reais de satisfação substitutiva.

Sabe-se que o amor, seja ele de fim inibido ou de fim não inibido, deriva do amor sexual. No entanto, se a libido encontra-se eficazmente recalcada, tem-se a ilusão de que o objeto amado tornou-se sensualmente amado devido aos seus méritos espirituais, embora o processo seja precisamente o contrário. Amam-se os méritos espirituais do objeto precisamente pelo encantamento sexual que ele pode produzir, embora quanto maior signifique para o Eu a distância entre o encantamento sexual e os méritos espirituais do objeto 
maior a dificuldade para que o Eu efetue, através do ideal do Eu, uma síntese entre a libido de fim inibido e de fim não inibido. (Freud, 1921a/1974)

O recalque estabelece a separação entre a libido inibida em sua finalidade e a de fim não inibido. Todavia, sabe-se que o ideal do Eu pode cumprir, além da função de incitar ao Eu o recalque, também a promoção de uma síntese entre ambas. Quando essa síntese não ocorre, a libido inibida em sua meta pode ser, de forma substitutiva, investida no enrijecimento reativo do ideal do $\mathrm{Eu}$ e este, mais uma vez, como forma de defesa, promove um novo recalque, aumentando os impedimentos dirigidos ao Eu. Em não proporcionando ao Eu uma reserva narcísica através da transformação de parte da libido objetal em libido do Eu, o ideal do Eu adquire cada vez mais intensamente a função de defesa aos investimentos diretos do Id, sem que o Eu possa beneficiar-se desses investimentos.

O resultado é a intensificação do recalque através da alta exigência do ideal do Eu. Embora ocorra a renúncia à parte da libido dirigida ao objeto sexual, não pode o Eu, nesse caso, fortalecer-se libidinalmente com os investimentos. Ao contrário, torna-se empobrecido. Na medida em que a libido encontra-se eficazmente recalcada, os impulsos cuja satisfação se dirige para a satisfação diretamente sexual são afastados para um segundo plano. O objeto de amor configura-se, destarte, como um substituto ideal para o $\mathrm{Eu}$, que permanece insatisfeito. “O ego se torna cada vez mais despretensioso e modesto e o objeto cada vez mais sublime e precioso, até obter finalmente a posse de todo o auto-amor do ego, cujo auto-sacrifício decorre, assim, como consequência natural” (Freud, 1921a/1974, p. 143).

As escolhas objetais podem, pois, ser indícios da forma como ocorreu o processo de identificação que resultou na formação do ideal do Eu. Ao investigar a relação entre os investimentos libidinais e o amor-próprio, Freud (1914a/2010) afirma ser necessário distinguir "se os investimentos amorosos estão em sintonia com o Eu ou se, ao contrário, experimentaram uma repressão" (Freud, 1914a/2010, p. 47). Quando os investimentos estão 
em sintonia com o Eu, o amar é tido como qualquer outra atividade do Eu. "O amar em si, enquanto ansiar, carecer, rebaixa o amor-próprio, e ser amado eleva-o novamente" (Freud, 1914a/2010, p. 47).

No entanto, se os investimentos objetais não se encontram em sintonia com o Eu, o investimento amoroso é sentido como grave diminuição do Eu e a satisfação amorosa torna-se impossível, visto a libido distanciada do Eu pelo recalque encontrar-se ligada à manutenção do Ideal do Eu em sua forma idealizada, não garantindo a satisfação do Eu no tocante ao objeto. Nesse caso, “o retorno da libido objetal ao Eu, sua transformação em narcisismo, representa como que um amor feliz novamente e, por outro lado, um real amor feliz corresponde ao estado primordial em que libido de objeto e libido do Eu não se distinguem uma da outra" (Freud, 1914a/2010, p. 47-48).

O risco dessa forma de investimento da libido na manutenção do ideal do Eu é que o desenvolvimento do Eu torna-se obstacularizado. Este desenvolvimento, a rigor, pressupõe um "deslocamento da libido para um ideal do Eu imposto de fora" (Freud, 1914a/2010, p. 48) e a satisfação seria decorrente do cumprimento desse ideal quando este se encontra em sintonia com os investimentos objetais libidinais do Eu.

Afinal, essa é a condição na qual o amor, a par de significar nas neuroses de transferência uma diminuição ${ }^{5}$ do que Freud (1914a/2010) nomeia de amor-próprio, pode também satisfazer-se de forma substitutiva a partir de novos investimentos objetais. Sabe-se que o $\mathrm{Eu}$ pode manter esse amor-próprio a partir de três fontes distintas que se encontram ligadas à possibilidade de o Ideal do Eu exercer sua função concernente à satisfação do Eu. “Uma parte do amor-próprio é primária, resto do narcisismo infantil; outra parte se origina da

\footnotetext{
${ }^{5}$ É fácil observar, além disso, que o investimento libidinal de objetos não aumenta o amor-próprio. A dependência do objeto amado tem efeito rebaixador; o apaixonado é humilde. Alguém que ama perdeu, por assim dizer, uma parte de seu narcisismo, e, apenas sendo amado, pode reavê-la. Em todos esses vínculos, o amor-próprio parece guardar relação com o elemento narcísico da vida amorosa (Freud, 1914a/2010, p. 46).
} 
onipotência confirmada pela experiência (do cumprimento do ideal do Eu); uma terceira, da satisfação da libido objetal" (Freud, 1914a/2010, p. 48).

A análise dos investimentos amorosos realizada por Freud (1914a/2010) elucidam, assim, questões concernentes ao processo de identificação. Entende-se que este pode envolver, predominantemente, a sublimação ou o recalque, embora o recalque seja um mecanismo originário e sempre subjacente à formação do Ideal do Eu. Afinal, o recalque é a primeira forma de renúncia do Eu à satisfação sexual mediante o reconhecimento do complexo de castração. Portanto, mesmo quando os investimentos amorosos estão em sintonia com o Eu, o ideal do Eu deixa em condições difíceis a satisfação libidinal nos objetos por censurar parte delas como intolerável. O que evidencia que a tensão entre o Eu e o ideal do Eu é inevitável, mesmo quando este realiza sua função de síntese entre a libido sexual inibida e não inibida de forma satisfatória.

Contudo, a função de síntese do ideal do Eu pode ou não ocorrer. Os caminhos que foram retratados expressam as possibilidades que se abrem a partir da puberdade, momento em que os investimentos amorosos denotam os desdobramentos da identificação. A identificação envolve, nesse caso, um abandono do objeto sexual, de modo que o que é preservado, podendo tomar diferentes destinos, é a libido dele retirada. Na melancolia, entretanto, a identificação se dá de forma distinta, não envolvendo a renúncia ao objeto sexual ainda que envolva uma transformação do Eu a partir da identificação ao objeto tomado como modelo.

É possível pensar que, a par de que o Supereu se estabeleça na melancolia como herdeiro do complexo de Édipo e resultante da identificação, não pode o ideal do Eu constituir-se na melancolia, desde que também o elevado ideal que se expressa no processo de idealização apresentado tampouco pode expressar a função de síntese do ideal do Eu. Essa síntese, sempre incompleta e insuficiente para as demandas do Id, viria da participação da 
sublimação na formação do ideal, ausente ou insuficiente tanto na melancolia como na excessiva idealização do objeto de amor colocado tantas vezes no lugar do ideal do Eu, impedindo que o Eu dele se diferencie.

$\mathrm{O}$ ideal do Eu que resulta da identificação é, portanto, parte do Eu modificada pela identificação a um traço do objeto tomado como modelo. A catexia da libido objetal retirada do objeto abandonado é transformada, em parte, em libido do $\mathrm{Eu}$, promovendo no $\mathrm{Eu}$ a identificação ao objeto. A transformação ocorrida preserva o objeto no Eu sob a forma do ideal do Eu, fazendo do objeto uma instância distinta do Eu. Essa separação possibilita a autoconservação narcísica do Eu na identificação ao seu objeto e também a satisfação da libido objetal, na medida em que o Eu pode tomar o objeto como modelo para satisfazer-se libidinalmente em sua relação com o Id, com o seu ideal e através da satisfação objetal.

Se, na formação do ideal do Eu que resulta da identificação, encontra-se em causa a substituição de uma catexia erótica pela identificação e uma transformação do Eu a partir do modelo objetal, o que diferencia a identificação na melancolia é o caráter indistinto entre a catexia do objeto e a identificação. Em $O E u$ e o Id, Freud (1923a/2011) refere-se à melancolia ponderando que, talvez, com a introjeção do objeto no Eu, que consiste numa regressão ao mecanismo da fase oral, o Eu facilite ou permita o abandono do objeto. "Talvez essa identificação seja absolutamente a condição sob a qual o Eu abandona os seus objetos (Freud, 1923a/2011, p. 36).

A identificação na melancolia não possibilita a constituição de um ideal do Eu, embora, contraditoriamente, se constitua na melancolia um rígido e severo Supereu. A perda do objeto para o melancólico resulta em identificação a ele, sem que o Eu possa apropriar-se da libido dele retirada. Reproduzindo a identificação o protótipo da identificação primária, em que o objeto é incorporado ao Eu, não pode o Eu distinguir para si e de si a satisfação sexual e a autoconservação. 
Assimilado ao Eu, torna-se o objeto uma sombra, que não se desfaz e nem se representa, de modo que a libido que ao Eu retrocede mantém a ligação entre o Eu e o objeto perdido. A pulsão de morte retorna como agressividade que não pôde ser dirigida para fora, vez que, para tal, seria necessário que o Eu participasse dos investimentos do Id. $\mathrm{Na}$ melancolia, o impulso erótico que poderia canalizar parte da agressividade para o mundo externo encontra-se mantendo a ligação entre o Eu e a sombra do objeto perdido. Nota-se que o empenho de Eros, nesse caso, é despender um enorme esforço para defender o Eu do retorno da agressividade.

Em Psicologia de Grupo e Análise do Ego, Freud (1921 a/1974) aborda as características e definições do processo de identificação e analisa que, na melancolia, o Eu encontra-se dividido, separado em duas partes: "Uma das quais vocifera contra a segunda. Esta segunda parte é aquela que foi alterada pela introjeção e contém o objeto perdido. Porém, a parte que se comporta tão cruelmente tampouco a desconhecemos" (Freud, 1921a/1974, p. 138). O objeto perdido na melancolia é incorporado regressivamente no $\mathrm{Eu}$, intensificando a ação do Supereu enquanto instância crítica, visto o Eu encobrir-se pela sombra do objeto. Na melancolia, a perda do objeto e a identificação a ele tem por finalidade a garantia de uma reserva narcísica como forma de preservar o objeto que não pôde se representar primitivamente no Eu.

Freud (1921a/1974), diante da constatação das diferentes possibilidades de identificação e distintos destinos libidinais, interroga-se sobre o que caracteriza o processo de identificação afinal. Trata-se, necessariamente, do abandono da catexia de objeto? É possível falar de identificação quando o objeto abandonado permanece sendo investido? Uma questão central para pensar a identificação e os modos de afecção psíquica em que a perda do objeto resulta em regressão ou introversão da libido é a alteração ou não da meta sexual. 
Sabe-se que a libido pode ser transformada ou desviada em sua finalidade sexual direta, mas não extinta, e a transformação tem por finalidade possibilitar ao Eu participar dos investimentos objetais. Trata-se de possibilitar ao Eu satisfazer-se internamente de forma narcísica com o objeto, diferenciando-se dele para resguardar, através da identificação a ele, sua função sexual preservada, embora alterada. Quando essa diferença não é preservada, a meta sexual inalterada exige que a libido, que não pôde seguir diretamente seu curso em busca da descarga, tome outros caminhos para obtê-la. Nesse caso, afirma Freud: "Levando em consideração as forças moventes que operam contrapondo-se à sequência de seu fluxo direto, pode-se também descrever os destinos pulsionais como espécies de defesa contra as pulsões" (Freud, 1915a/2013, p. 35).

Freud (1915a/2013) refere-se a dois outros destinos libidinais que aparecem como modalidade de defesa contra a pulsão. São eles: a reversão da libido em seu contrário e o retorno em direção à própria pessoa. A primeira divide-se em dois processos distintos: a conversão da atividade em passividade e a inversão de seu conteúdo, ou seja, a transformação do amor em ódio. Freud afirma que o essencial em ambos os processos é a mudança de objeto com a meta inalterada, de modo que a finalidade permanece sendo a descarga pulsional direta. A convergência desses dois destinos libidinais - a reversão da libido em seu contrário e o retorno em direção à própria pessoa - será detalhada no próximo capítulo por referir-se aos desdobramentos da identificação ao objeto perdido na melancolia.

Nota-se que, tanto na melancolia em que o objeto perdido é substituído pela identificação a ele como na identificação do Eu não a um objeto, mas a um traço do objeto abandonado, ocorre uma alteração do Eu. Entretanto, no segundo caso, ao apropriar-se do traço de um objeto, o Eu distingue-se dele em sua semelhança, preservando no Eu os precipitados dessa diferença. "Se o Eu assume os traços do objeto, como que se oferece ele 
próprio ao Id como objeto de amor, procura compensá-lo de sua perda, dizendo: 'Veja, você pode amar a mim também, eu sou tão semelhante ao objeto’ (Freud, 1923a/2011, p. 37).

Nota-se a modificação da meta sexual nessa forma de alteração do Eu. Essa modificação significa que a descarga para a libido retirada do objeto sexual pode ser encontrada através da preservação da função sexual, embora não no objeto de satisfação abandonado. No processo, parte da energia dirigida ao objeto foi aproveitada pelo Eu para estabelecer novas ligações com seu ideal do Eu, preservando a função sexual do Eu.

Tudo se passa como se, através da identificação, o Eu pudesse controlar o Id e aprofundar com ele suas relações, "embora à custa de uma larga tolerância para com as experiências dele" (Freud, 1923a/2011, p. 37). O estabelecimento de um ideal do Eu cumpre a função de possibilitar ao Eu uma relação com o $\mathrm{Id}$, de modo a apropriar-se de seus investimentos, livrando-se, entretanto, de seus investimentos diretos.

Nessa direção, a identificação na melancolia coloca em evidência uma relação entre o Eu e o Supereu em que o ideal do Eu revela-se ausente enquanto síntese que possibilita um fortalecimento do Eu a partir de uma transformação de parte da libido objetal em libido do Eu. Essa característica da melancolia, além de auxiliar na compreensão dessa afecção psíquica, aponta para a importância da função do ideal do Eu em sua relação com o objeto perdido, estruturante da constituição psíquica. Ainda assim, vale retomar a afirmação de Freud: “Em muitos indivíduos, a separação entre o ego e o ideal do ego não se acha muito avançada e os dois ainda coincidem facilmente" (Freud, 1921a/1974, p. 163).

\subsection{A severidade do Supereu: o sentimento de culpa e a necessidade de punição}

Sabe-se que a severidade do Supereu decorre, em grande parte, da agressão assumida pelo Supereu advinda do impulso hostil voltado para dentro (Freud, 1930a/1974). No entanto, 
é também o Supereu que, ao representar no Eu os objetos abandonados pela libido, pode, como um acréscimo de libido ao Eu, possibilitar um novo destino para a destrutividade decorrente da renúncia ao objeto sexual. O Supereu representa, por conseguinte, não somente a consciência moral decorrente do retorno da agressividade ao Eu que, de forma reativa, opõese a essa agressividade, mas também uma reserva narcísica que, sob a forma do ideal do Eu, gabarita o Eu a participar de novos investimentos objetais do Id, dominando-os e obtendo com eles novas formas de descarga.

A libido erótica investida na identificação ao modelo objetal, quando pode agregar a si, sob a forma do Supereu, parte da agressividade, de modo que ela não represente uma ameaça para o Eu, pode conduzi-la em parte para o mundo externo. Todavia, outra parte dessa agressividade permanece no Eu, manifestando-se como uma tensão permanente entre o Eu e o Supereu, denominada sentimento de culpabilidade.

O sentimento de culpa, a severidade do superego, é, portanto, o mesmo que a severidade da consciência. É a percepção que o ego tem de estar sendo vigiado dessa maneira, a avaliação da tensão entre os seus próprios esforços e as exigências do super-ego. O medo desse agente crítico (medo que está no fundo de todo relacionamento), a necessidade de punição, constitui uma manifestação instintiva por parte do ego, que se tornou masoquista sob a influência de um superego sádico; é, por assim dizer, uma parcela do instinto voltado para a destruição interna presente no ego, empregado para formar a ligação erótica com o superego (Freud, 1930 a/1974, p.160-161).

A caracterização desse sentimento explicita que o "sentimento de culpa é o mais importante problema no desenvolvimento da civilização", além de "demonstrar que o preço que pagamos por nosso avanço em termos de civilização é uma perda da felicidade pela intensificação do sentimento de culpa" (Freud, 1930 a/1974, p. 158). A rigor, somente a partir da constituição do Supereu se pode falar de uma de suas funções: a consciência (moral). Uma vez constituído, não existe mais a diferença entre uma agressividade pretendida e uma 
agressividade executada, dado que a percepção do $\mathrm{Eu}$ da severidade desse representante parental internalizado é uma continuação da agressividade primitivamente a este dirigida, que impunha restrições à satisfação erótica.

Analisando a atuação da pulsão de morte na formação do Supereu, tem-se, portanto, duas possibilidades que não se conciliam, mas não se excluem. A energia punitiva deriva da autoridade externa que se mantém viva na mente ou, de acordo com outra opinião, consiste na própria energia agressiva que não foi utilizada e que é dirigida contra essa autoridade inibidora. As observações clínicas demonstram que, em relação a essas duas fontes da agressividade atribuídas ao Supereu, uma delas pode exercer um efeito mais forte que a outra em casos determinados, embora, em geral, operem em harmonia.

A excessiva severidade do Supereu, em alguns casos, evidencia o efeito mais forte da energia agressiva atuante no Supereu, parecendo haver uma quebra entre essas duas fontes da qual deriva a agressividade. Freud (1933a/1974) refere-se à melancolia como um quadro clínico que tem como aspecto mais evidente o modo "como o superego - 'consciência', podem denominá-la assim, tranquilamente - trata o ego" (Freud, 1933a/1974). Nessa afecção psíquica, o Supereu goza de um determinado grau de autonomia para a obtenção de sua energia, agindo segundo suas próprias intenções e de forma independente do Eu.

Embora um melancólico possa, assim como outras pessoas, mostrar um grau maior ou menor de severidade para consigo mesmo nos seus períodos sadios, durante um surto melancólico seu superego se torna super severo, insulta, humilha e maltrata o pobre ego, ameaça-o com os mais duros castigos, recrimina-o por atos do passado mais remoto, que haviam sido considerados, à época, insignificantes - como se tivesse passado todo intervalo reunindo acusações e apenas tivesse estado esperando por seu atual acesso de severidade a fim de apresentá-las e proceder a um julgamento condenatório, com base nelas. $O$ superego aplica o mais rígido padrão de moral ao ego indefeso que lhe fica à mercê; representa, em geral, as exigências da moralidade, e compreendemos imediatamente que nosso sentimento moral de culpa é expressão da tensão entre o ego e o superego (Freud, 1933a/1974, p. 79). 
Freud (1930a/1974), em O Mal Estar na Civilização, faz uma importante análise sobre a severidade excessiva do Supereu. Sabe-se que esta não representa exclusivamente a rigidez da figura parental tomada como modelo, mas também as primeiras representações do Eu deste objeto. Essa representação envolve as primeiras catexias objetais abandonadas, às quais se juntam as posteriores identificações. Essa colocação é importante para que o Supereu não seja reduzido ao objeto externo. “A severidade original do superego não representa - ou não representa tanto - a severidade que dele [do objeto] se experimentou ou que se lhe atribui. Representa, antes, nossa própria agressividade para com ele” (Freud, 1930a/1974, p. 153).

A análise da agressividade do Supereu apresentada por Freud (1930a/1974 a) introduz uma consideração importante sobre o sentimento de culpa na formação do Supereu. Ele afirma que, de modo geral, existe uma predileção pela ideia "de que qualquer tipo de frustração, qualquer satisfação instintiva frustrada, resulta, ou pode resultar, numa elevação do sentimento de culpa" (Freud, 1930a/1974). Todavia, contesta essa tese questionando-se: “como devemos explicar, em fundamentos dinâmicos e econômicos, um aumento do sentimento de culpa que aparece no lugar de uma exigência erótica não satisfeita?" (Freud, 1930a/1974). Ao que responde:

Isso só parece possível de maneira indireta se supusermos que a prevenção de uma satisfação erótica exige uma agressividade contra a pessoa que interferiu na satisfação, e que essa própria agressividade, por sua vez, tem de ser recalcada. Se as coisas se passam assim, é, em suma, apenas a agressividade que é transformada em sentimento de culpa, por ter sido recalcada e transmitida para o superego (Freud, 1930a/1974, p. 163).

Com essa análise, Freud deriva o sentimento de culpa da pulsão agressiva, donde se entende que a elevação do sentimento de culpabilidade, que se expressa na excessiva consciência moral do Supereu, pode resultar também de uma agressividade recalcada da qual 
provém a força punitiva do Supereu. Contudo, a satisfação substitutiva na melancolia não é encontrada no sintoma, que ainda expressa uma tendência conciliatória do Eu entre os interesses contrários das várias instâncias psíquicas, mas na regressão da libido ao Eu. Aplicando a tese que afirma que o sentimento de culpa deriva de um impulso agressivo insatisfeito, Freud (1930 a/1974) relaciona essa derivação ao processo do recalque e afirma:

Os sintomas neuróticos são, em sua essência, satisfações substitutivas para desejos sexuais não realizados. No decorrer do nosso trabalho analítico, descobrimos, para nossa surpresa, que talvez toda neurose oculte uma cota de sentimento inconsciente de culpa, o qual, por sua vez, fortifica os sintomas, fazendo uso deles como punição (Freud, 1930 a/1974, p. 163).

Sabe-se que, quando uma tendência pulsional experimenta o recalque, seus elementos libidinais transformam-se em sintomas e seus componentes agressivos, em sentimento de culpa. E o que parece elucidar a questão sobre o aumento da severidade do Supereu que se liga a um aumento do sentimento de culpa é a impossibilidade do Eu de beneficiar-se dos componentes libidinais através de satisfações substitutivas. O Supereu, na melancolia, não se origina da força do Eu fortalecido pela identificação a um "ideal do Eu imposto de fora" (1914a/2010), mas da força da energia agressiva que, mantendo-se recalcada e atuante, garante a vinculação libidinal entre o Eu e o Supereu através das sucessivas renúncias pulsionais à agressividade.

Dessa maneira, uma vez constituído o Supereu, cada nova renúncia pulsional se torna “fonte dinâmica de consciência, e cada nova renúncia aumenta a severidade e a intolerância desta última" (Freud, 1930a/1974, p. 152). O Supereu pode tornar-se excessivamente rígido e severo, expressando uma formação reativa à agressividade primitivamente recalcada. Nesse caso, evidencia ter-se constituído, exclusivamente, como forma de defesa contra as fortes catexias do Id (formação reativa), embora não manifeste em sua atuação a força de Eros 
aliada ao Eu. Nota-se, nesse caso, na relação entre o Eu e o Supereu, a ausência do ideal do Eu como mediador no domínio entre o Id e o Supereu.

Sabe-se que perda do objeto, na melancolia, leva a regressão da libido de volta ao Eu. A libido retirada do objeto perdido e reinvestida no Eu representa-se, agora, subjetivamente, não mais como um conflito entre o Eu e o objeto perdido, mas, sobretudo, como um conflito entre o Eu modificado pela identificação ao objeto perdido e sua instância crítica. O Eu, nesse caso, vincula-se libidinalmente ao objeto perdido, restando ao Supereu a agressividade que, sadicamente, é dirigida e satisfeita de forma masoquista pelo Eu.

A constituição do ideal do Eu, a rigor, efetiva-se com a dissolução do complexo de Édipo e encontra no Supereu sua forma "bem sucedida de identificação com a instância parental" (Freud, 1933a/1974, p. 83). Entretanto, o ideal do Eu nem sempre aparece como mediador nesse processo. É comum que as histórias que envolvam as escolhas objetais eróticas permaneçam afastadas da instância que representa a continuidade dos primeiros conflitos entre o Eu e o Id a partir do complexo de Édipo: o Ideal do Eu. Resta saber “(...) até que ponto o caráter ${ }^{6}$ de uma pessoa rejeita ou acolhe estas influências da história de suas escolhas eróticas de objeto" (Freud, 1923a/2011, p. 36).

Algumas vezes, pode o Supereu, rejeitando as escolhas objetais primitivas do Eu, constituir-se com base em identificações que representem tão somente uma defesa aos interesses libidinais do Id, ao invés de assegurar também sua satisfação. Quando isso ocorre, ainda que o Supereu constitua-se como "expressão dos mais poderosos impulsos do Id" e um dos “mais importantes destinos libidinais do Id" (Freud, 1923a/2011, p.36), não pode o Eu gratificar-se em seu ideal.

\footnotetext{
${ }^{6}$ Freud associa esse termo, em $O$ Eu e o Id (1923 a/2011), à configuração do Eu. Ele associa essa configuração ao processo de identificação primordial que se encontraria na base do que se denomina "caráter" (Freud, 1923/2011, p. 35).
} 
A história da gênese do Super-eu torna compreensível que velhos conflitos do $\mathrm{Eu}$ com os investimentos objetais do Id possam prosseguir em conflitos com o herdeiro destes, o Super-eu. Quando o Eu não consegue dominar o complexo de Édipo, o investimento de energia deste, oriundo do Id, volta a operar na formação reativa do ideal do Eu. A profusa comunicação entre esse ideal e esses impulsos instintuais ics resolve o enigma de o ideal mesmo poder ficar em grande parte inconsciente, inacessível ao Eu (Freud, 1923a/2011, p. 49).

$\mathrm{O} \mathrm{Eu}$, nesse caso, desconhece as demandas a que responde e também a origem da satisfação encontrada. Daí, a importância da compreensão da relação inconsciente entre o Id e o ideal do Eu e da forma de satisfação pulsional que se instaura quando a libido, desligada do objeto perdido, alia-se à compulsividade pulsional (pulsão de morte), que tem como objeto de descarga direta o próprio Eu. Freud (1923a/2011) ressalta que é "o comportamento do ideal do $\mathrm{Eu}$, que determina a gravidade de uma doença neurótica" (Freud, 1923a/2011, p. 63). 


\section{CAPÍTULO 3: MELANCOLIA}

\subsection{Caracterização da melancolia}

O luto como experiência psíquica de perda, ainda que seja um sofrimento extremamente penoso, pode também, após certo tempo e trabalho árduo, levar a um desinvestimento psíquico do objeto perdido, de modo que a energia que o sofrimento despendia no enlutado possa tonar-se livre para novos investimentos. O luto e a melancolia, tal qual trabalhados por Freud (1917a/2011), referem-se a um sofrimento decorrente de uma perda, real ou ideal, de um objeto a quem alguém se vincula. Na impossibilidade de viver um trabalho de luto, o sofrimento dele decorrente pode prolongar-se de forma a tornar-se patológico, transformando-se, algumas vezes, em melancolia.

Este capítulo pretende investigar o lugar ocupado pelo objeto na melancolia e a compreensão da organização das forças pulsionais que sustentam essa forma de funcionamento psíquico. Sendo a melancolia uma neurose narcísica, refere-se a um “comprometimento decorrente do encontro primitivo com o Outro, do vínculo originário, fundador" (Peres, 2011, p.123). Além disso, figura na obra freudiana como afecção que denuncia as possibilidades do ódio na constituição psíquica em todas as suas vertentes.

Em Luto e Melancolia, Freud (1917a/2011) não faz referência ao tema da depressão, mesmo que, em determinados momentos, utilize o termo. A palavra depressão aparece para se referir a "depressões de tipo obsessivo" e em contraposição à mania, "depressão e inibição da melancolia”. Para Kehl (2011), autora que escreve o prefácio de uma das traduções do texto Luto e Melancolia ${ }^{7}$, além de outra obra referente ao tema ${ }^{8}$, a teoria freudiana da melancolia

\footnotetext{
${ }^{7}$ Freud, Sigmund [1856-1939]. Luto e Melancolia. Título original: Trauer und melancholie. Textos: Maria Rita Kehl, Modesto Carone, Urania Tourinho Peres. Tradução, introdução e notas: Marilene Carone. São Paulo: Cosac Naify, 2011, 144 pp.

${ }^{8}$ Ver O Tempo e o Cão: a atualidade das depressões. Maria Rita Kehl. São Paulo: Boitempo, 2009.
} 
representa duas importantes rupturas. No plano clínico, Freud aproximou o tema da clínica psicanalítica, retirando-o da exclusividade da clínica psiquiátrica. No plano das ideias, sua teoria afastou a melancolia da tradição advinda desde a Antiguidade Grega, que a associava às representações sublimes atribuídas aos homens de caráter melancólico.

O suposto de que a melancolia, na obra de Freud, foi afastada das representações mais sublimes encontra outras interpretações. Para Peres (2011), no século XX, Freud retoma, para além da questão, o termo "melancolia", que havia desaparecido dos manuais de psiquiatria substituído pela palavra “depressão". A retomada do termo tinha o intuito de garantir-lhe um espaço no campo de sua invenção: a psicanálise.

Invenção que bordeja arte e ciência, lamento e criação, capaz de acolher as 'dores da alma', gravadas na singularidade das marcas que definem a fortuna de cada ser humano. Tormento de difícil tradução, pois a palavra não alcança o enigma de nossa existência, que se trama nas vicissitudes das perdas e seus lutos" (Peres, 2011, p. 105-106).

A cautela de Freud (1917 a/2011) em conceituar a melancolia - utilizando-se desse termo e não de outro - advém da dificuldade em apreender um conceito único para a doença em função das diversas formas em que se apresenta o sofrimento melancólico. O constante confronto com o luto, enquanto manifestação não patológica de uma reação à perda de um objeto, expressa a complexidade da tarefa a que se dedicara. De outro lado, o estudo sobre a melancolia brota também das questões sobre o narcisismo, sobretudo a partir da constatação da escolha objetal de base narcisista (Freud, 1914a/2010).

Nesse campo, Freud investiga a diferença entre as parafrenias e as neuroses de transferência bem como o lugar do Eu não somente em sua função de defesa às constantes catexias libidinais provindas do Id, mas também como reservatório de libido, para o qual esta poderia, inclusive, retornar através da sua regressão ao Eu. Com essa descoberta, a compreensão de novas formas de organização psíquica foi aprofundada, entre elas a 
melancolia, que evidencia um conflito distinto tanto da neurose como da psicose no que concerne à atuação de determinadas forças pulsionais e ao lugar ocupado pelo Eu em sua relação com outras instâncias do psiquismo, o Id e o Supereu.

Afastando a melancolia da psiquiatria, Freud (1917a/2011) descobre, nessa afecção psíquica, o ódio recalcado a um objeto de amor precocemente perdido, o que seria também a origem inconsciente das autoacusações melancólicas. Para Peres (2011), o melancólico sofre de uma grande ânsia de amor. Não por acaso Freud estabelece a relação entre o padecer de "uma grande ânsia de amor" e o momento inicial de entrada na vida, momento no qual a ânsia de amor cumpre seu papel estruturante" (Peres, 2011, p.106-107)

Sabe-se que a melancolia é emblema de uma reação à perda em que, diferentemente do luto, o sujeito desconhece não o objeto que se perdeu enquanto objeto de amor, mas o que perdeu de si com a perda do objeto. Ao desconhecer o que, psiquicamente, se perde a partir de uma perda real, o sujeito melancólico ou sucumbe ao objeto, identificando-se a ele, com fortes características de autorrecriminações a si mesmo; ou o domina numa condição maníaca, buscando, por exemplo, sobre ele certo triunfo. Essa característica diferencia a melancolia do trabalho de luto e ressalta a importância da compreensão do lugar ocupado pelo objeto no luto e na melancolia e a função por ele assumida.

O objeto não é algo que realmente morreu, mas que se perdeu como objeto de amor (por exemplo, o caso de uma noiva abandonada). Em outros casos, ainda nos acreditamos autorizados a presumir uma perda desse tipo, mas não podemos discernir com clareza o que se perdeu e com razão supomos que o doente também não é capaz de compreender conscientemente o que ele perdeu. Poderia ser também esse o caso de quando o doente conhece qual é a perda que ocasionou a melancolia, na medida em que de fato sabe quem ele perdeu, mas não o que perdeu nele [no objeto]. Isso nos levaria a relacionar a melancolia com uma perda de objeto que foi retirada da consciência, à diferença do luto, no qual nada do que diz respeito à perda é inconsciente (Freud, 1917 a/2011 a, p. 50-51). 
Uma das características distintivas da melancolia em relação ao luto é a regressão da libido ao Eu. No luto, a libido, após a perda do objeto, regride ao investimento das lembranças do objeto perdido como forma de preservá-lo temporariamente, até que esses investimentos se desfaçam. O equacionamento disso ocorre entre o mundo externo que atesta a inexistência do objeto cotidianamente e o $\mathrm{Eu}$ que, lentamente, pode desligar-se do investimento dessas lembranças, preservando vivo o Eu e disponibilizando a libido para novos investimentos.

Na melancolia, o processo é diferente. Retira-se do objeto perdido o investimento nele realizado. No entanto, a libido vinculada ao objeto não retorna ao investimento da lembrança do objeto perdido, podendo, posteriormente, liberar-se para novos investimentos, mas substitui o investimento no objeto pelo investimento no Eu sob a forma da identificação. De forma que o objeto eleito objeto de amor na melancolia parece preservar estreita sintonia com o objeto que, inicialmente, se constituiu para o Eu objeto de identificação. Essa relação tornase considerável, visto que, no melancólico, uma escolha objetal regride para a identificação.

Veja-se, portanto, a especificidade da identificação e dos investimentos libidinais na melancolia.

\subsection{Melancolia: a especificidade da identificação}

A melancolia é uma afecção psíquica caracterizada por Freud (1924a/2011) como uma neurose narcísica. “Apresenta-se sob várias formas clínicas, cuja síntese em uma unidade não aparece assegurada" (Freud, 1917a/2011). Pode ser definida por um desânimo profundo e doloroso, perda da capacidade de amar, inibição de toda atividade, diminuição de autoestima que se expressa em autorrecriminações e suspensão do interesse pelo mundo externo. Ademais, constitui-se reação à perda real ou afetiva de uma pessoa amada. 
À exceção do rebaixamento da autoestima, todas as características elencadas podem também ser encontradas no estado de luto, que se refere também à reação à perda de uma pessoa amada. No entanto, no luto, tem-se a realização de um trabalho de elaboração em que o objeto perdido, mesmo que consuma todo o investimento psíquico do enlutado durante o período posterior à perda, lentamente deixa de mobilizar esses investimentos, liberando-os para novos interesses.

O estudo da melancolia possibilitou a Freud (1917a/2011) um aprofundamento sobre a identificação e a complexa função do Eu no funcionamento psíquico. A melancolia refere-se à dificuldade de desligamento da libido de um objeto de amor. A substituição do investimento objetal pelo investimento erótico do Eu revela que a escolha objetal, na melancolia, estabelece-se sobre uma identificação narcísica ao objeto. Desse modo, a identificação pode tornar-se igualmente um sucedâneo do investimento amoroso e assim, apesar do conflito, a relação amorosa com o objeto amado não precisa ser abandonada, a par de que o objeto o seja.

Tal substituição do amor objetal por identificação é um mecanismo importante para as afecções narcísicas; recentemente K. Landauer pôde descobri-la no processo de cura de uma esquizofrenia. Corresponde naturalmente à regressão de um tipo de escolha de objeto para o narcisismo originário. Em outro lugar, mostramos que a identificação é a etapa preliminar da escolha de objeto, e é a primeira modalidade, ambivalente na sua expressão, pela qual o ego distingue um objeto. Ele gostaria de incorporá-lo, na verdade, devorando-o, de acordo com a fase oral ou canibalística do desenvolvimento libidinal (Freud, 1917a/2011, p. 62-63).

A regressão que vai do investimento no objeto amoroso para a identificação desencadeada pela experiência de perda denota a força que ainda conserva o narcisismo originário na melancolia. A identificação primordial ou primária referida por Freud como etapa preliminar da escolha de objeto é "mais antiga do que qualquer investimento objetal" (Freud, 1923a/2011, p. 39). Sabe-se que as escolhas objetais pertencentes ao primeiro período 
sexual referentes a pai e mãe resultam também em uma identificação que reforça a identificação primária. Essa análise permite inferir que existe, por conseguinte, na melancolia, uma ligação entre a escolha de objeto de base narcisista e o retorno da libido a um estado primordial narcísico do Eu, em que o investimento objetal é indistinto da identificação.

No entanto, Freud (1917a/2011) pondera sobre a insuficiência do material clínico para confirmar a constatação de que a enfermidade melancólica baseia-se no predomínio da escolha narcisista de objeto, muito embora reafirme a importância da caracterização da melancolia a partir da "regressão do investimento de objeto à fase oral, que ainda pertence ao narcisismo" (Freud, 1917a/2011, p.62-63). Além disso, na melancolia, com a experiência da perda, uma identificação narcísica ao objeto de amor torna-se o substituto para uma escolha objetal de modo que a perda do objeto pode transformar-se em perda do Eu e o conflito entre a pessoa amada e o Eu "em uma bipartição entre a crítica do ego e o ego modificado pela identificação" (Freud, 1917a/2011, p. 60-61).

Existe algo que se percebe imediatamente a partir dos pressupostos e dos resultados de um tal processo. Por um lado, deve ter havido uma forte fixação no objeto de amor e, por outro, e em contradição com isso, uma pequena resistência do investimento objetal. De acordo com uma pertinente observação de Otto Rank, essa contradição parece requerer que a escolha de objeto tenha sido feita sobre uma base narcísica, de modo que o investimento objetal possa regredir para o narcisismo se se defrontar com dificuldades (Freud, 1917a/2011, p. 62-63).

A identificação, mesmo constituindo-se sempre sobre as bases de uma identificação primária, é, sobretudo, um precipitado no Eu deixado pela renúncia ao objeto eleito objeto de amor. É a primeira modalidade, ambivalente em sua forma de expressão, a partir da qual o Eu distingue um objeto.

De outro lado, a diferença estabelecida por Freud entre a identificação narcísica e a identificação histérica em Luto e Melancolia elucida questões importantes sobre a 
identificação na melancolia. A identificação narcísica diferencia-se da identificação histérica "pelo fato de que na primeira se abandona o investimento do objeto, ao passo que na segunda ele persiste" (Freud, 1917a/2011, p. 64-65).

Se a identificação narcísica pressupõe o abandono do investimento no objeto, trata-se, na melancolia, de um desinvestimento no objeto desprovido de uma transformação ou de um desvio da libido nele investida. A transformação poderia levar à formação de um precipitado no $\mathrm{Eu}$, derivado da herança do objeto abandonado. A regressão da libido a um estágio de formação do Eu, em que a identificação ao objeto é ainda indiscernível da catexia objetal, evidencia a tentativa de reencontrar um objeto primitivo que não pôde ser abandonado.

A forte fixação ao objeto de amor na melancolia e a baixa resistência do investimento objetal expressam que a distinção de um objeto para o Eu, base do processo de identificação, ancorou-se em bases frágeis na melancolia, de modo que uma frustração na relação com o objeto pode levar à sua substituição pelo Eu. Compreendendo que a identificação é um legado do complexo de Édipo, que pressupõe o encontro com a castração, infere-se que, na melancolia, a dificuldade em distinguir um objeto para o Eu a partir do qual o Eu possa diferenciar-se envolve a dificuldade do enfrentamento da castração para o melancólico. A afecção melancólica retrata uma impossibilidade de renúncia ao objeto perdido, de que decorre o recuo do melancólico diante de uma ameaça de perda, dificultando o enfrentamento com o conflito ambivalente que a perda do objeto impõe. Ainda que o objeto seja desinvestido, é transformado, entretanto, em parte irrenunciável do próprio Eu.

A afecção melancólica evidencia, portanto, a possibilidade de uma falha na constituição inicial do Eu, que desencadeia, na melancolia, uma tentativa de restauração da falha através das subsequentes escolhas objetais ou da manutenção do complexo melancólico. Este envolve a relação que se estabelece entre o Eu e o Supereu e tem por finalidade suturar, por via da identificação do Eu ao objeto perdido, a falha na constituição primária do Eu. 
Não tendo ocorrido uma representação unificada primária para a catexia objetal que, originariamente, não se distingue do Eu, entende-se que o Eu não se fortalece com a libido e tampouco se reconhece como um objeto, permanecendo, todavia, submetido à força libidinal. Nessas condições, o objeto, ainda que se torne atuante no Eu, como defesa primária a uma excitabilidade não representada, revela-se insuficiente para oferecer unidade e representação a uma primeira junção, sempre temporária, entre a libido e a autoconservação. Dessa maneira, o objeto é ora afastado do Eu ora incorporado, para que o Eu, sem representação, possa defender-se e beneficiar-se da libido, sem, contudo, representar-se como objeto de satisfação.

Entende-se que esse processo se desdobra posteriormente nos caminhos que derivam do complexo de Édipo e do enfrentamento com a castração. A rigor, a identificação derivada do Édipo pressupõe a renúncia ao objeto eleito objeto de amor, embora não um desinvestimento completo do objeto para o $\mathrm{Eu}$, que pode, da libido retirada do objeto, beneficiar-se, transformando-se conforme o modelo tomado para o Eu. Sabe-se, contudo, que o que pode derivar, ao contrário do processo descrito, da impossibilidade de distinguir um objeto para o Eu é a identificação do Eu ao objeto que não pode ser renunciado, embora seja desinvestido.

Sendo a castração o complexo que envolve a ameaça ao narcisismo e encontra-se, a partir do complexo de Édipo, na origem da renúncia ao objeto sexual eleito objeto de amor, pressupõe-se, a partir de Freud (1917 a/2011), que, na melancolia, há, no enfrentamento com a castração, atualizada por toda ameaça de perda, a experiência de uma ameaça primitiva. Esta coloca em cena, diferentemente do mesmo processo nas neuroses de transferência, a ameaça não somente à satisfação narcísica do Eu, mas sobretudo à existência do Eu como objeto de amor. Essa diferença justificaria o recuo do melancólico diante da ameaça de castração. Afinal, se, originariamente, o Eu não se constitui como um objeto de satisfação ou se constitui 
de forma falha, posteriormente torna-se mais complexo a identificação representar-se como um processo de distinção de um objeto para o Eu.

Freud (1917a/2011) afirma que, nas neuroses de transferência, diferentemente da melancolia, a identificação, conhecida também como um mecanismo atuante na formação de sintomas, expressa outro movimento do sujeito diante da castração. Embora o processo, nesse caso, também seja o de substituição de uma catexia objetal pela identificação, o sintoma, derivado da libido que não pode ser satisfeita e tampouco sublimada pelo Eu, representa uma tentativa de conciliação entre os interesses do Id e do Eu, expressando, por conseguinte, uma via possível para a libido recalcada retirada do objeto sexual abandonado.

O investimento no objeto, destarte, persiste enquanto busca de satisfação e "exterioriza um efeito que habitualmente se limita a certas ações e inervações isoladas" (Freud, 1917a/2011, p. 64-65). Na melancolia, ao contrário, o objeto é desinvestido para que o Eu seja representado pela identificação ao objeto. Os desdobramentos dessa substituição evidenciamse de forma mais clara em outros destinos pulsionais, que serão apresentados ainda neste capítulo.

Em Narcisismo: uma introdução, Freud (1914a/2010) distingue entre as parafrenias e as neuroses de transferência no que se refere ao afastamento face ao mundo externo. Essa distinção parece importante para a compreensão dos desdobramentos da diferença do processo de substituição do investimento objetal pela identificação na afecção melancólica, neuroses de transferência e parafrenias. Ademais, também na melancolia, trata-se de um afastamento da realidade, embora o objeto incorporado garanta ao $\mathrm{Eu}$, de forma distorcida, uma representação e manutenção da realidade que não se constituiu originariamente no Eu.

O afastamento do parafrênico face ao mundo externo pede uma caracterização mais precisa. Também o histérico e o neurótico obsessivo abandonam, até onde vai sua doença, a relação com a realidade. A análise mostra, porém, que de maneira nenhuma suspendem a relação erótica com pessoas e coisas. Ainda a mantêm na 
fantasia, isto é, por um lado substituem os objetos reais por objetos imaginários de sua lembrança, ou os misturam com estes, e por outro lado renunciam a empreender as ações motoras para alcançar as metas relativas a esses objetos (...) Sucede de outro modo com o parafrênico. Este parece mesmo retirar das pessoas e coisas do mundo externo a sua libido, sem substituí-las por outras na fantasia (Freud, 1914a/2010, p. 15).

Na melancolia, o desinvestimento da realidade é semelhante ao do parafrênico, ainda que não ocorra no melancólico uma reclusão ou uma entrega e disponibilidade frente à realidade externa. Se o desinvestimento do objeto, representativo da identificação narcísica (Freud, 1917a/2011), não significa o abandono do investimento sexual, também o investimento objetal e a identificação são a princípio indistintos e, apenas com o narcisismo, enquanto representação corpórea unificada do Eu, torna-se possível distinguir uma energia sexual (libido) da libido do Eu. A função dessa distinção é que o Eu possa satisfazer-se com a satisfação libidinal, embora para isso seja necessário, antes, que o Eu possa representar-se como parte da experiência de prazer.

\subsection{A ambivalência primordial e as vicissitudes libidinais na melancolia}

A ambivalência primordial mobilizada na melancolia pela experiência da perda, mesmo que de forma inconsciente, adquire relevância ainda maior quando articulada à identificação. Se a identificação propriamente dita tem por função a distinção de um objeto para o Eu, uma das razões disso é a possibilidade de oferecer um destino diferente do Eu para a libido, de modo que o Eu não permaneça sem defesas submetido à força desta. Porém, a identificação deixa marcas, já que deriva também da identificação primária, como aponta Freud (1917a/2011), em que, a princípio, o Eu incorpora o objeto, "na verdade, devorando-o, de acordo com a fase oral ou canibalística do desenvolvimento libidinal” (Freud, 1917a/2011, p. 62-63). 
A forma como a ambivalência se configura na melancolia é importante para pensar os desdobramentos desse processo. Sabe-se que a ambivalência, ainda que seja, em sua origem, expressão do conflito entre o Eu e o objeto presente ou ausente, representa-se como um conflito entre o Eu e o Supereu na melancolia. O amor e o ódio nos processos primários do Eu ainda não se distinguem das experiências de prazer-desprazer, evidenciando, na melancolia e nas neuroses de transferência, a dependência do amor às primeiras formas de satisfação. Tampouco distinguem o objeto da satisfação.

Quando o objeto se ausenta, sentem-se o desprazer e o ódio e, quando satisfaz e se aproxima, o prazer e o amor. Somente com o narcisismo enquanto unificação das pulsões parciais antes desorganizadas, através da qual o Eu representa-se como objeto, é que também o desprazer e o ódio experimentam uma primeira fusão. A fusão pode aquiescer o Eu, embora torná-lo também sujeito ao desprazer que, de alguma forma, significa uma elevação de tensão que o Eu pode manter em suspenso e adiá-la para satisfazer-se depois.

Entretanto, na melancolia, a identificação narcísica ao objeto de amor evidencia a impossibilidade de o Eu adiar ou suspender a satisfação, ligando a libido desinvestida imediatamente ao objeto incorporado. O objeto cumpre, então, a função de preservar o amor, com o Eu se dividindo para defendê-lo do ódio. De outro lado, reproduz-se na relação entre o Eu e o Supereu a ambivalência primordial, tornando-se "a perda do objeto na melancolia uma oportunidade extraordinária para que entre em vigor e venha à luz a ambivalência das relações amorosas" (Freud, 1917a/2011, p. 64-65).

Esse conflito de ambivalência, de origem ora mais real, ora mais constitutiva, não deve ser desconsiderado entre os pressupostos da melancolia. Se o amor pelo objeto - um amor que não pode ser abandonado, ao mesmo tempo que o objeto o é - se refugiou na identificação narcísica, o ódio entra em ação nesse objeto substitutivo, insultando-o, humilhando-o, fazendo-o sofrer e ganhando nesse sofrimento uma satisfação sádica (Freud, 1917a/2011, p. 66-67). 
A ambivalência na melancolia elucida o destino do ódio quando a libido desinvestida do objeto regride para a identificação. O que está em causa, como se refere Freud (1917a/2011), é “um amor que não pode ser abandonado, ao mesmo tempo em que o objeto o é". Trata-se de uma inversão. Nas neuroses de transferência, ocorre a renúncia ao objeto sexual como forma de garantir a satisfação narcísica, enquanto, na melancolia, se renuncia ao investimento no objeto para garantir uma unidade ao Eu.

A ambivalência tal qual se manifesta no melancólico é importante, pois, por elucidar tanto uma falha na constituição do narcisismo como os destinos do ódio que entra em ação em um objeto que não se constituiu de forma separada do Eu. As autorrecriminações do melancólico representam um ódio dirigido ao objeto do qual o Eu não se desvincula, colocando em evidência os desdobramentos da ambivalência primordial. Na tentativa de elucidar as características da ambivalência, busca-se articular a relação entre o desinvestimento do objeto na melancolia e a manutenção desse investimento nos estreitos limites do Eu.

Em Psicologia de Grupo e Análise do Ego, Freud (1921a/1974) refere-se ao homossexualismo e à melancolia como exemplos da introjeção do objeto no Eu que remetem à identificação narcísica. Ao discorrer sobre a gênese do homossexualismo e sobre a melancolia, destacando suas especificidades, Freud enfatiza um modo de identificação em que o Eu é remoldado em um de seus aspectos mais importantes, em seu caráter sexual.

A questão exemplificada por Freud (1921 a/1974) sobre a introjeção do objeto no Eu já havia sido desenvolvida em Luto e Melancolia. Entretanto, é abordada em ambos os textos com questionamentos distintos, mas que remetem a uma mesma perquirição. Em relação à introjeção do objeto no Eu que se evidencia na gênese da melancolia, Freud (1921a/1974) questiona-se se esta leva à renúncia ao objeto em si mesmo ou se, de alguma forma, ele é preservado apenas no inconsciente. "Neste processo, o objeto em si mesmo é renunciado, se 
inteiramente ou se no sentido de ser preservado apenas no inconsciente sendo uma questão que se acha fora do escopo do presente estudo" (Freud, 1921a/1974, p. 137).

Em Luto e Melancolia, a questão é saber se a renúncia ao objeto perdido, que se representa pelo desinvestimento do objeto na melancolia, significa de fato uma renúncia ao objeto ou se, de outra forma, ele permanece mobilizando investimentos. Além disso, ao referir-se sobre a forma como ocorre o desligamento da libido do objeto perdido, são questionadas (Freud, 1917a/2011) as instâncias entre as quais esse processo ocorre. "O que dos processos psíquicos dessa afecção ainda se passa nos investimentos objetais inconscientes que foram abandonados e o que se passa em seu substituto por identificação, dentro do ego?” (Freud, 1917a/2011, p. 78-79).

Freud (1917a/2011) esclarece que a representação inconsciente do objeto perdido é abandonada. Todavia, a representação envolve inúmeras impressões singulares (traços inconscientes) que permanecem sendo mobilizadas e que dificultam o desligamento rápido da libido do objeto. O desligamento da libido do objeto ocorre, pois, tanto na melancolia como no luto, de forma lenta, na medida em que a perda do objeto mobiliza a ambivalência tanto no que se refere a cada uma das ligações amorosas do Eu, mobilizadas pela perda, como também à ambivalência primitiva das experiências surgidas da ameaça de perda do objeto.

A ambivalência é ou constitucional, isto é, inerente a cada uma das ligações amorosas desse ego, ou surge justamente das experiências acarretadas pela ameaça de perda do objeto. Por isso a melancolia pode, quanto aos motivos que a ocasionam, ir muito mais longe do que o luto, que via de regra só é desencadeado pela perda real, a morte do objeto. Na melancolia se tramam, portanto, em torno do objeto inúmeras batalhas isoladas, nas quais ódio e amor combatem entre si: um para desligar a libido do objeto, outro para defender contra o ataque dessa posição da libido (Freud, 1917a/2011, p. 80-81). 
A questão crucial no que se refere à diferença entre a ambivalência desencadeada por uma perda no luto e na melancolia é que, na última, o amor e ódio combatem entre si, estando a ambivalência vinculada às experiências acarretadas pela ameaça de perda do objeto que, diferentemente do luto, colocam em cena a ameaça ao Eu que não pode do objeto desvincularse. Ademais, não obstante que, em ambos, a batalha entre o amor e ódio se efetive no inconsciente, na melancolia, ao contrário do luto, as lutas travadas entre o amor e o ódio não podem tornar-se conscientes como um conflito entre o Eu e o objeto perdido.

Esse caminho está bloqueado para o trabalho melancólico, talvez em consequência de inúmeras causas ou de uma ação conjunta de causas. A ambivalência constitutiva pertence em si mesma ao reprimido, e as experiências traumáticas com o objeto podem ter ativado um outro material reprimido. Assim, dessas lutas de ambivalência tudo permanece subtraído à consciência, enquanto não sobrevém o desenlace característico da melancolia. Este consiste, como sabemos, no fato de que o investimento libidinal ameaçado finalmente abandona o objeto, mas só para se retirar de volta ao lugar do ego do qual havia partido. Desse modo, o amor deixou de ser eliminado por sua fuga para o ego. Depois dessa regressão da libido o processo pode se tornar consciente e se representa para a consciência como um conflito entre uma parte do ego e a instância crítica (Freud, 1917a/2011, p. 82-83).

Freud (1915a/2013) afirma, em As Pulsões e seus Destinos, que, quando uma relação de amor com um objeto é rompida, o ódio pode assumir seu lugar dando a impressão de uma transformação do amor em ódio. Contudo, ao aprofundar a investigação, descobre que o ódio desencadeado pela perda do objeto é um ódio primitivamente recalcado e pode se associar e se fortalecer pela regressão da libido (amor) ao estágio sádico preliminar. Nesse caso, o ódio assume um caráter erótico e é garantida a continuidade de uma relação amorosa nos estreitos limites do Eu.

A melancolia evidencia um destino para a libido descrito por Freud (1915 a/2013) neste mesmo texto: "o retorno em direção à própria pessoa". No caso, o destino da libido funciona como uma defesa frente às pulsões que tiveram seu desenvolvimento libidinal 
impedido. Vale lembrar que o essencial nesse processo "é a troca do objeto com a invariância da meta" (Freud, 1915a/2013, p. 65).

A libido desliga-se do objeto e regride ao $\mathrm{Eu}$ sem sofrer uma alteração em sua natureza; abdica do objeto, substituindo-o pela identificação, sem ocorrer uma alteração na meta sexual. Sendo a catexia erótica substituída pela identificação ao objeto perdido sem que a finalidade sexual sofra um desvio ou transformação, a libido deve encontrar outra forma de satisfação. Não tendo ocorrido uma alteração na natureza da libido, efetiva-se também em sintonia com o retorno da libido ao Eu a reversão da pulsão em seu contrário, como forma de oferecer à ambivalência primordial uma organização. A reversão ocorre de duas formas distintas: a conversão da atividade em passividade e a inversão de seu conteúdo. Freud (1915a/2013) afirma:

Exemplos do primeiro processo são dados pelos pares de opostos sadismo-masoquismo e voyeurismo-exibicionismo. A reversão diz respeito apenas às metas da pulsão; sua meta ativa: atormentar, contemplar, é substituída pela passiva: ser atormentado, ser contemplado. A inversão de conteúdo pode ser encontrada no caso único da transformação do amar em um odiar. (Freud, 1915a/2013, p. $35)$.

O processo parece ocorrer da seguinte forma: não podendo encontrar satisfação em sua forma ativa, a libido sofre uma alteração em sua meta no que concerne à forma de obter satisfação, sem que a finalidade sexual sofra nenhuma alteração, desvio ou suspensão. Na melancolia, a libido assume sua forma passiva, satisfazendo-se através da passividade masoquista do Eu submetida à atividade sádica do Supereu. Trata-se de uma tentativa da libido de encontrar a satisfação sexual em sua forma direta, sem que ao Eu tenha sido possível dominá-la. A vinculação libidinal que mantêm a ligação entre o Eu e o Supereu fundamentase na defesa ao ódio que é mantido afastado do Eu como forma de preservar viva essa relação. 
Freud (1915a/2013) oferece uma definição da relação existente entre o par de opostos sadismo-masoquismo quando ocorre a convergência desses dois destinos libidinais: o retorno em direção à própria pessoa e a reversão em seu contrário. A definição é elucidativa por expressar uma analogia que se pretende fazer com a relação existente entre o Eu e o Supereu na melancolia e as vicissitudes libidinais possíveis quando a catexia objetal é substituída pela identificação e a libido retorna ao Eu.

Quanto ao par de opostos sadismo-masoquismo, o processo pode ser apresentado da seguinte forma: a) $\mathrm{O}$ sadismo consiste em prática de violência, exercício de poder tendo uma outra pessoa como objeto. b) Esse objeto é abandonado e substituído pela própria pessoa. Com a volta contra a própria pessoa também se realiza a transformação da meta instintual ativa em passiva. c) Novamente se busca uma outra pessoa como objeto, a qual, em virtude da transformação de meta ocorrida, tem de assumir o papel de sujeito (Freud, 1915a/2013, p. $65)$.

Se o conflito entre o Eu e o objeto perdido e a ambivalência desencadeada nesse processo torna-se consciente na melancolia somente quando toma a forma do complexo melancólico que se representa como um conflito entre o Eu e o Supereu, é necessário compreender a relação que sustenta esse conflito. Sabe-se que o Eu, identificado ao objeto perdido, comporta-se como um objeto através do qual o Supereu, enquanto sujeito do Eu, satisfaz de forma sádica e ativa o ódio recalcado que retorna sob a forma da rígida consciência moral. Apesar de empobrecido, por não fortalecer-se com o amor do Supereu, o Eu encontra sua forma de satisfação e representação na subsunção masoquista ao Supereu.

Freud (1915a/2013) afirma existirem três polaridades para a forma como se configura a relação primordial entre o amor e o ódio. Em oposição ao estado inicial de indiferença das pulsões quanto ao mundo externo, tem-se a forma como atua interna e originariamente no psiquismo: a relação amor-ódio, a relação amor e ódio e a relação amar-ser amado. Esta última "corresponde à conversão da atividade em passividade e pode igualmente remontar a 
uma situação fundamental, como a pulsão de olhar. Tal situação seria: amar a si mesmo, o que para nós caracteriza o narcisismo" (Freud, 1915a/2013, p. 49).

As três oposições para o amor são referidas nesse contexto por ajudarem a compreender que, mesmo que provisoriamente, o amor seja definido como a relação do Eu com suas fontes de prazer, envolvendo a ambivalência característica dessa relação, o amar efetivamente coincide com a totalidade da procura sexual. No entanto, quando a libido regride para estágios anteriores do desenvolvimento libidinal, o ódio pode expressar sua condição originária, como é o caso do sadismo que se volta contra o Eu na melancolia.

O caso do amor e do ódio adquire um interesse especial, dada a circunstância de não se ajustarem ao nosso enquadramento da apresentação das pulsões. Não se pode duvidar da íntima relação entre esses sentimentos opostos e a vida sexual, mas se deve relutar em conceber o amor como uma espécie de pulsão parcial específica da sexualidade como as outras. Preferiríamos considerar o amor como sendo a expressão de toda aspiração sexual, mas com isso não avançamos muito, nem chegamos a saber como se deve compreender o contrário material dessa aspiração (Freud, 1915a/2013, p. 49).

Os estágios preliminares do amor antecedem à síntese pulsional que coincide com a procura da totalidade sexual. Apresentam-se como metas sexuais temporárias das pulsões para os quais as mesmas podem regredir. O primeiro dos estágios preliminares do amor e constitutivo do narcisismo é o estágio de satisfação autoerótica. Neste, há a abolição da existência separada do objeto na medida em que o Eu desenvolve-se a partir da incorporação do objeto que é aniquilado e a fonte de satisfação ainda se encontra no corpo. No segundo estágio, também constitutivo do narcisismo primário, surge a procura pelo objeto de satisfação, não importando se ele é danificado ou aniquilado. Esse segundo estágio corresponde à antítese entre o amar e o ser amado, momento durante o qual o objeto é amado quando propicia prazer, de forma que amar é correspondente a ser amado. 
Reconhecemos como a primeira dentre essas fases a de incorporar ou devorar, como uma forma de amor compatível com a suspensão da existência em separado do objeto, podendo, portanto, ser caracterizada como ambivalente. Na fase mais elevada da organização pré-genital sádico-anal, aparece o anseio pelo objeto na forma do ímpeto pela dominação, ao qual é indiferente o dano ou a aniquilação do objeto. Essa forma e essa fase preliminar do amor quase não se diferenciam do ódio em sua conduta diante do objeto. Somente quando estabelecida a organização genital o amor se torna o oposto do ódio (Freud, 1915a/2013, p. 61).

A relação ambivalente e primitiva entre o amor e o ódio na melancolia, precisamente por tratar-se de uma regressão libidinal, dificulta o desligamento da libido do Eu, que se tornou identificado à sombra do objeto. $\mathrm{O}$ Eu identificado ao objeto submete-se passivamente ao Supereu, garantindo à ambivalência uma representação que defende o Eu da ameaça de aniquilamento ou de indistinção. Através da "reversão de seu conteúdo" e do "retorno em direção à própria pessoa", a libido retorna ao Eu e pode, enfim, preservar-se nas amarras do complexo melancólico da ameaça de destruição.

Nesse sentido, a perda do objeto mobiliza de forma intensa a ambivalência primordial e coloca em cena a angústia que deriva da ameaça de castração atualizada pelo temor da consciência moral. De forma regressiva, a perda se torna uma ameaça ao próprio Eu. Se o amor, no estágio narcísico, corresponde ao ser amado, quando o amor se desfaz sem que ele tenha constituído-se como possibilidade de experiência de suspensão, a ameaça que se impõe ao Eu é de aniquilamento. A sobrevivência do Eu na melancolia está em estreita dependência do amor e de um amor que se representa, sobretudo, como defesa ao ódio primitivamente recalcado. A angústia que sobressai desse estado evidencia uma enorme liberação da libido narcísica.

O complexo melancólico não por acaso mobiliza um intenso investimento de energia que, nas neuroses de transferência, atua como um contrainvestimento. O investimento no complexo melancólico pretende ligar, de forma regressiva, a libido desligada do objeto, na 
iminência de evitar a angústia. O excessivo investimento no complexo melancólico, representado pelo conflito entre o $\mathrm{Eu}$ e o Supereu, tem como desdobramento o empobrecimento do $\mathrm{Eu}$, que não pode se fortalecer com o Supereu. Na melancolia, o investimento amoroso no objeto tem, assim, um duplo destino: "por um lado regrediu à identificação, mas, por outro, sob a influência do conflito de ambivalência, foi remetido de volta à etapa do sadismo, mais próxima desse conflito" (Freud, 1917 a/2011, p. 68-69).

Freud (1917 a/2011) questiona-se sobre como poderia um quantum tão excessivo de libido narcísica desligada do objeto levar o melancólico ao suicídio, na manifestação de um caso extremado. A questão, segundo ele (1917 a/2011), parece controversa, visto o suicídio configurar-se como a efetivação da angústia de destruição tão temida e evitada pelo Eu. Tratase, em certo sentido, da consumação da angústia da qual o Eu tenta escapar por todas as vias.

Destarte, refere-se a dois estados nos quais, por extremos opostos, o Eu evidencia-se completamente subjugado ao objeto: nos casos de suicídio na melancolia e nos estados extremados de enamoramento. O que se encontra, no suicídio, é o retorno da hostilidade dirigida ao objeto para o próprio $\mathrm{Eu}$. $\mathrm{O} \mathrm{Eu}$, tratando-se como um objeto, atualiza, com a frustração desencadeada pela perda, a reação primordial do Eu de ódio contra os objetos do mundo externo. Na melancolia, o Eu tornou-se identificado ao próprio objeto. “Assim, na regressão a partir da escolha narcísica de objeto, o objeto foi de fato suprimido, mas provou ser mais poderoso que o próprio ego" (Freud, 1917 a/2011, p. 68-69).

O suicídio e o enamoramento, em suas formas extremas, expressam o empobrecimento do Eu que, entretanto, mantém vivo o amor por meio de uma satisfação masoquista. $\mathrm{Na}$ melancolia, a angústia desencadeada pelo excesso de liberação de libido narcísica encontra sua via de resolução de duas formas distintas: numa delas representa-se no completo imobilismo do melancólico preso às amarras de seu complexo; na outra, se manifesta na forma da mania, contraface da melancolia e que representa o outro polo de um mesmo 
complexo melancólico. Nesta, a libido narcísica liberada é investida no próprio Eu, desligando-se temporariamente do Supereu.

\subsection{A mania e o complexo melancólico: a contraface da melancolia}

A compreensão da mania oferece subsídios para expressar como o desligamento da libido do objeto, que proporciona a liberação de angústia narcísica, é uma forma de fornecer outros destinos para a libido represada no Eu na melancolia. “A peculiaridade mais notável da melancolia, a que mais requer esclarecimento é a sua tendência a se transformar no estado sintomaticamente oposto da mania" (Freud, 1917a/2011, p. 72-73).

Sabe-se que nem toda melancolia transforma-se em mania. Contudo, alguns casos que Freud (1921a/1974) caracteriza como depressão excessiva referindo-se à melancolia, atravessam um estado intermediário, chegando a uma exaltada sensação de bem-estar. Ele acrescenta que os fundamentos dessa oscilação espontânea de um estado de ânimo são desconhecidos e que não se sabe sobre o mecanismo que leva ao deslocamento de uma melancolia para uma mania.

Toma como referência dois pontos de apoio para buscar os fundamentos de um complexo melancólico na mania. São eles: uma impressão psicanalítica e uma experiência econômica geral. Sabe-se que a mania não se distingue da melancolia no que Freud (1917a/2011) nomeia de complexo melancólico. As duas afecções lutam com o mesmo "complexo", com a diferença de que, na melancolia, o Eu sucumbe ao complexo e, na mania, domina-o ou o coloca de lado. Tem-se, portanto, um mesmo conteúdo na mania e na melancolia.

O segundo ponto de apoio a que Freud (1917a/2011) se refere liga-se à exaltação do estado de ânimo, alegria, júbilo e triunfo encontrado na mania em oposição à inibição 
melancólica. Constata, fundamentando-se nas análises do Eu propiciadas pela compreensão da melancolia, que, em alguns pacientes, "seu ideal do ego poderia ter-se temporariamente convertido no ego, após havê-lo anteriormente governado com especial rigidez" (Freud, 1921a/1974, p. 166).

Com base em nossa análise do ego, não se pode duvidar que, nos casos de mania, o ego e o ideal do ego se fundiram, de maneira que a pessoa, em estado de ânimo de triunfo e auto-satisfação, imperturbada por nenhuma autocrítica, pode desfrutar a abolição de suas inibições, sentimentos de consideração pelos outros e autocensuras (Freud, 1921a/1974, p. 166-167).

$\mathrm{Na}$ origem do complexo melancólico, encontra-se um conflito que se expressa à consciência como um conflito entre o Eu e o Supereu. O Eu converteu-se em objeto e o Supereu, em sujeito, numa relação sádico-masoquista. O objeto de amor foi abandonado porque "demostrou ser indigno de amor", sendo, por conseguinte, "novamente erigido dentro do ego, mediante identificação, e severamente condenado pelo ideal do ego" (Freud, 1917a/2011).

Se há semelhança no complexo que mobiliza os investimentos na mania e na melancolia, compreende-se que, do ponto de vista econômico, a mania expressa a alteração da catexia mantida por longo tempo represada na rígida relação entre o Eu e o Supereu. Com a disponibilidade da libido, esta se torna livre para múltiplas aplicações e possibilidades de descarga. A sensação de triunfo experimentada na mania representa o triunfo do Eu antes oprimido pelo Supereu.

Entretanto, visto o conflito entre o Eu e o Supereu representar-se à consciência como um conflito entre o Eu e sua instância crítica, de modo que a instância crítica estabelece-se como defesa frente ao Id, permanece oculto na mania e afastado do domínio (consciente) do Eu o que ele suplantou e sobre o que ele triunfa. Ainda assim, nota-se que a diluição temporária do Supereu no Eu promove a liberação da libido antes represada, possibilitando 
novos investimentos, ainda que o Eu não demonstre ter adquirido uma representação e tampouco uma experiência de seu sofrimento. A sensação de triunfo experimentada no estado de mania é uma característica ausente no trabalho de luto, que também constitui um trabalho de elaboração e desligamento da libido do objeto perdido. Essa evidência coloca entre parênteses a ideia de que, na mania, o triunfo do Eu corresponda a uma libertação do objeto que ocasionou o sofrimento.

O luto normal também supera a perda de objeto e enquanto dura ele absorve igualmente todas as energias do ego. Por quê, depois que passou, não há indícios de que se produziu nele a condição econômica para uma fase de triunfo? Acho impossível responder de imediato a essa objeção. Ela chama nossa atenção para o fato de que sequer podemos dizer por que meios econômicos o luto realiza sua tarefa, mas talvez aqui possa ser útil uma conjectura. Em cada uma das recordações e situações de expectativa que mostram a libido ligada ao objeto perdido, a realidade traz à tona o seu veredicto de que o objeto não existe mais e o ego, por assim dizer, indagado se quer compartilhar esse destino deixa-se determinar pela soma de satisfações narcísicas dadas pelo fato de estar vivo, e desfaz sua ligação com o objeto aniquilado. Podemos imaginar que esse desligamento se dá tão lenta e gradualmente, que ao terminar o trabalho também se dissipou o gasto que ele requeria (Freud, 1917a/2011, p. 76-77/78-79).

O trabalho de exercer um veredito sobre a realidade, que promove o desligamento lento da libido do objeto perdido no luto, mesmo que esteja entre as funções atribuídas ao Supereu, torna-se impedido na melancolia. A predominância do modo de identificação narcisista faz do Supereu, no melancólico, o representante de uma defesa excessiva que se vincula de forma direta aos investimentos do Id. Quanto maior a força sexual não desviada do Eu identificado ao objeto mais intensa a força do recalque, que cobra seu preço na contínua elevação da consciência moral na melancolia.

O Supereu, nesse caso, representa, sobretudo, o ódio primitivo dirigido aos primeiros objetos do Eu. Mesmo tendo sido, posteriormente, assimilados a ele novos objetos de identificação, ele cumpre a mesma função de defesa reativa ao ódio originário. O Supereu 
representa, portanto, na melancolia, uma reação sádica ao ódio recalcado e que permaneceu mobilizando intensos investimentos.

Sabe-se que duas características importantes da melancolia também estão presentes no luto, quais sejam: a perda do objeto e a ambivalência. O retorno da libido ao Eu, todavia, é distintivo da melancolia e encontra-se ausente no trabalho de luto. A mania com seu estado de triunfo representa uma alteração nos modos de distribuição da libido que, temporariamente, torna-se livre das imposições sádicas e cruéis do Supereu. Porém, ainda que a libido torne-se disponível para novos investimentos, ao contrário do que aparenta, ela não se torna livre do objeto ideal perdido.

Aquele acúmulo de investimento a princípio ligado, que se libera com o término do trabalho melancólico possibilitando a mania, deve estar relacionado com a regressão da libido ao narcisismo. $\mathrm{O}$ conflito no ego, que a melancolia troca pela luta em torno do objeto, tem de operar com uma ferida dolorosa, que exige um contrainvestimento extraordinariamente elevado. (Freud, 1917a/2011, p. 85-85).

Essa característica da mania a torna interessante sob vários aspectos. A economia no dispêndio de energia empregada na manutenção do complexo melancólico é, na mania, investida intensamente no Eu, que triunfa sobre o objeto. A mania, por representar em sua origem o triunfo sobre um objeto do qual o Eu não se desvincula, embora o faça temporariamente, acena para a possibilidade de um fracasso da repetição que mantém o complexo melancólico. Se essa é a condição que coloca o sujeito frente à angústia é também a possibilidade de oferecer à libido outro destino.

\subsection{O Eu e o Supereu: "uma gradação diferenciadora no ego"}

Sabe-se que a formação do Supereu abarca, entre suas funções, a auto-observação, a consciência e o ideal do Eu e envolve uma relação de diferenciação entre o Eu e o Supereu. O 
estudo das neuroses tornou familiar o fato de que essa relação entre o Eu e o Supereu representa uma ação recíproca total entre o mundo externo e o Eu com seus investimentos objetais (Freud, 1921a/1974).

Cada uma das diferenciações psíquicas que se observa no Eu após o complexo de Édipo representa um novo agravamento das dificuldades de funcionamento mental, "podendo tornar-se o ponto de partida para sua desintegração, isto é, para o desencadeamento de uma doença” (Freud, 1921a/1974, p. 164). A constituição do ideal do Eu pressupõe um abandono de catexias objetais que colocam em causa, de certo modo, a passagem do narcisismo primário para o narcisismo secundário. No curso desse desenvolvimento, nunca linear, efetuase uma separação entre um Eu coerente e uma parte inconsciente e reprimida separada da coerência do $\mathrm{Eu}$, o que evidencia que a estabilidade do funcionamento psíquico se acha exposta a abalos constantes.

O estudo da melancolia revelou-se determinante na explicitação dessa instabilidade psíquica que pode levar a regressões ou a outros sintomas. A parte inconsciente e reprimida que se afasta do Eu coerente pode atuar de diferentes formas, revelando-se também na atuação da rigidez do Supereu em suas constantes relações com o Id, não mediadas pelo ideal do Eu. Ou, por exemplo, como nas neuroses obsessivas, em que, não havendo uma regressão da libido ao Eu como na melancolia, a atuação da rigidez inconsciente do Supereu converte o amor que não pode ser satisfeito em hostilidade, recalcando esse afeto que se deve manter afastado do Eu. Em ambas as afecções, nota-se que o aspecto inconsciente do Eu não se restringe ao Id, mas é também tantas vezes expressão do Supereu em sua consciência moral.

A passagem do narcisismo primário para o secundário no funcionamento psíquico não é uma aquisição permanente, o que se evidencia nos sintomas, regressões e inibições. Em Psicologia de Grupo e Análise do Ego, Freud (1921a/1974) afirma que a separação que se efetiva (quando se efetiva) entre o ideal do Eu e o Eu não pode ser mantida por muito tempo, 
sendo temporariamente desfeita. Os chistes e o humor, segundo Freud, cumprem em grande parte essa função, fazendo uso de artifícios especiais "para permitir que o que está reprimido contorne as resistências e o recebamos temporariamente em nosso ego, para aumento de nosso prazer" (Freud, 1921a/1974, p. 165). Outro exemplo do rompimento temporário da separação entre o ideal do eu e o Eu é fornecido por Freud pela análise dos rituais e comemorações festivas.

\begin{abstract}
Em todas as renúncias e limitações impostas ao ego, uma infração periódica da proibição é a regra. Isso, na realidade, é demonstrado pela instituição dos festivais, que, na origem, nada mais eram do que excessos previstos em lei e que devem seu caráter alegre ao alívio que proporcionam. As saturnais dos romanos e o nosso moderno carnaval concordam nessa característica essencial com os festivais dos povos primitivos, que habitualmente terminam com deboches de toda espécie e com a transgressão daquilo que, noutras ocasiões, constituem os mandamentos mais sagrados. Mas o ideal do ego abrange a soma de todas as limitações a que o ego deve aquiescer e, por essa razão, a revogação do ideal constituiria necessariamente um magnífico festival para o ego, que mais uma vez poderia então sentirse satisfeito consigo próprio. (Freud, 1921a/1974, p. 165- 166).
\end{abstract}

A relação entre o ideal do Eu e o Eu coloca em evidência questões importantes referentes à identificação e à formação do mesmo ideal. A questão entre ambos fundamentase em dois problemas centrais: a permanência ou não do objeto abandonado no Eu e a regressão da libido ao Eu, de forma que ambas encontram-se indissoluvelmente interligadas.

A neurose obsessiva, mais uma vez, tendo em comum com a afecção melancólica as penosas e torturantes objeções da consciência, encontra-se imune (ao contrário da melancolia) ao perigo da autodestruição. "Compreendemos que é a conservação do objeto que garante a segurança do Eu". (1923a/2011, p. 67). Na neurose obsessiva, o fato de que o objeto permaneça no $\mathrm{Eu}$ como objeto modificado faz com que o Eu não se torne objeto das tendências destrutivas a partir da regressão à organização pré-genital. Essas tendências permanecem no Id e o Eu se opõe a elas por formações reativas e medidas de precaução. O 
fato de que o objeto permaneça no Eu a partir da identificação impede a regressão da libido a ele, de modo que essa sofre a ação do recalque.

Na melancolia, tem-se outro processo de destino libidinal. O objeto, não tendo sido conservado como parte distinta do Eu e, portanto, como libido objetal, promove naquele uma alteração pelo viés do objeto tomado não como modelo, mas como objeto total. A libido destrutiva desligada de um impulso erótico é, então, separada do Eu pela ação do recalque, embora, nesse caso, não retorne reativamente como forma de obter uma satisfação substitutiva através do sintoma, como na neurose obsessiva. Na melancolia, diferentemente, o ódio que retorna é assumido pelo Supereu, de maneira que o Eu, identificado e vinculado ao objeto perdido pelo amor, transforma-se em objeto no qual o ódio encontra descarga. É a esse processo que Freud (1923a/2011) se refere ao dizer que o objeto, não permanecendo no Eu, tornou-se mais potente que o próprio Eu.

$\mathrm{O}$ Eu, na melancolia, converte-se, em sua dependente relação com o Supereu, à sede da angústia. Essa, segundo Freud (1923a/2011), não corresponde ao vago medo da morte senão à angústia da consciência moral. "O ser superior, que se tornou ideal do Eu, ameaçou uma vez com a castração, e esse medo da castração é provavelmente o núcleo em volta do qual se armazena a posterior angústia da consciência, é ele que prossegue como angústia da consciência" (Freud, 1923a/2011, p. 72).

A compreensão da angústia no que se refere ao Eu na melancolia expressa que a liberação do investimento libidinal narcísico, outrora investido numa escolha de objeto, regride ao Eu a partir da perda. Se, para o Eu, viver significa ser amado, e o Supereu desempenha a função protetora que tinha "antes o pai, depois a Providência ou o Destino", quando esse mesmo Eu se encontra diante de um perigo real, ele se deixa morrer. "O Eu abandona a si mesmo, por sentir-se odiado e perseguido pelo Super-eu, em vez de amado" (Freud, 1923a/2011, p. 73). 
Nota-se, por conseguinte, que o medo da morte na melancolia é representado pelo medo da consciência moral, que se expressa na sua relação de dependência do Supereu. A angústia experienciada pelo $\mathrm{Eu}$, mesmo que atualize a "situação que subjaz ao primeiro grande estado de angústia, o do nascimento, e à angústia infantil da nostalgia, a da separação da mãe protetora" (Freud, 1923 a/2011, p.73), se representa no Eu na melancolia como medo que advém de sua relação com a consciência moral.

A angústia auxilia a compreensão de que a melancolia, ainda que expresse o desinvestimento libidinal da realidade, representa, sobretudo, a presença ausente do objeto no Eu, que torna o Eu empobrecido e o objeto excessivamente poderoso e investido sob a forma de um complexo melancólico. Além disso, a identificação aparece, no complexo melancólico, como processo decisivo no que concerne aos rumos do narcisismo secundário.

Na melancolia, a constituição do Supereu a partir da identificação resultou em uma instância que, se sustenta a consciência moral, não possibilita ao Eu beneficiar-se dos investimentos objetais do Id, de modo a oferecer-lhes uma satisfação substitutiva. Desse modo, torna-se expressão sobretudo de uma formação reativa às exigências do Id. Em outras palavras: o Supereu, herdeiro do complexo de Édipo, que poderia representar psiquicamente o outro do Eu enquanto expressão do que lhe faz marca da diferença, tornou-se expressão direta, embora revertida em outra instância, das exigências do Id, de modo a fazer do Eu, por uma inversão da pulsão em seu conteúdo e em sua regressão ao Eu, objeto de hostilidade.

Ademais, sabe-se que a identificação pode se equacionar de modo distinto e resultar em diferentes afecções ou estruturas psíquicas. Ocorre que a identificação, a rigor, pressupõe a distinção de um objeto para o Eu. Quando bem sucedida, possibilita ao Eu ser outro, com a ressalva de nunca ser o outro. A internalização do outro no Eu lhe faz potência e limite e torna o ideal do Eu expressão em parte dos anseios do Id. Estes, alterados pelo Eu em consonância ao ideal do Eu, impulsionam-no às relações objetais. 
O Eu transforma-se para continuar satisfazendo o Id e o ideal do Eu. Através dos objetos externos, atende à exigência de descarga dos anseios do Id e, satisfazendo o Id, pode realizar-se também, em certa medida, em relação ao ideal do Eu. A realidade psíquica, nesse caso, torna-se expressão de um entremeio que se encontra entre o sujeito e a realidade. $\mathrm{O}$ sujeito lança-se para o mundo ao reconhecer-se no objeto e ao distinguir-se dele, fortalecendo-se.

$\mathrm{O}$ "desenvolvimento do Eu" consiste no afastamento do narcisismo primário. Quando o ideal do Eu planifica-se com o Eu, mantendo-se reflexo de uma condição narcísica invertida pela rigidez (formação reativa) dos objetos de satisfação incorporados, pode-se dizer de um narcisismo secundário que se sobrepõe a um narcisismo primário, não ocorrendo um desenvolvimento das relações do Eu quanto aos seus investimentos libidinais. O direcionamento da libido aos objetos fundamenta-se, nesse caso, menos na consciência, muito embora se respalde intensivamente na moralidade que assume o Eu para si.

Em Psicologia de Grupo e Análise do Ego, a gradação diferenciadora entre o Eu e o ideal do Eu definida por Freud (1921a/1974) possui um limite tênue, mas bem delimitado. A necessidade de romper esse limite de tempos em tempos como forma de desfrutar de um prazer preliminar expressa a sua tenacidade. Na melancolia, o limite entre o Eu e o ideal do Eu encontra-se diluído, enfraquecido, podendo esse limite tomar tanto a forma da excessiva consciência moral, que se define bem na relação entre o Supereu e o Eu que sustenta o complexo melancólico, como também apresentar-se completamente diluído nas fases maníacas da melancolia. A rigidez de ambos os estados, uma vez mais, representa a impossibilidade de sustentação da diferença sem que o limite se torne uma ameaça mortífera ao amor. 


\section{CONSIDERAÇÕES FINAIS}

O estudo da melancolia constituiu um desafio no percurso deste trabalho e o propósito de compreendê-la a partir de textos da obra freudiana impôs algumas dificuldades. A primeira delas pode ser referida à localização dos textos específicos na obra de Freud que tivessem como objeto definido de elaboração teórica a melancolia. O tema, que é explicitamente elaborado em Luto e Melancolia, foi nele, no entanto, desenvolvido na esteira do estudo sobre o narcisismo, o que colocou importantes questões no que concerne à identificação.

Outra dificuldade foi articular o narcisismo e a identificação a partir de dois tempos distintos, embora inseparáveis, porque a melancolia coloca em evidência a substituição de um investimento objetal pela identificação ao objeto desinvestido e a regressão da libido ao Eu. $\mathrm{Na}$ origem desse processo, encontra-se uma identificação narcísica a um objeto de amor.

A dificuldade em apreender esses dois tempos distintos e interligados da identificação e do narcisismo surgiu do fato de que a identificação primária, ainda que preceda a identificação da qual resultam as escolhas sexuais pertencentes ao primeiro período sexual, não pode ser identificada antes que se possa distinguir um objeto para o $\mathrm{Eu}$, o que, na melancolia, revela-se um percurso complexo. A identificação primitiva como sendo direta e imediata é mais antiga que qualquer investimento objetal e encontra-se ligada à fase oral de desenvolvimento da libido.

Por isso, a relação entre o Eu e o objeto e a separação entre o Eu e o Supereu, tal qual se configuram na melancolia, revelaram-se mediações fundamentais na compreensão dessa afecção psíquica. Ainda que o narcisismo como estágio inicial da libido esteja subjacente à identificação, ele revela-se, na melancolia, presente também nas escolhas objetais de modo a impossibilitar a renúncia à parte da catexia objetal. Nesse ponto, a melancolia revelou-se uma afecção psíquica na qual a dificuldade de distinção de um objeto para o Eu, que se liga à 
impossibilidade de renunciar ao objeto de amor, impede que o Eu se constitua libidinalmente, não podendo, portanto, separar-se e tampouco unir-se ao objeto pelo viés do ideal do Eu.

O desdobramento desse processo é que tanto a separação, que se expressa na melancolia pela autonomia que o Supereu adquire frente ao $\mathrm{Eu}$ sob a forma de consciência moral, como a identificação, que se sustenta na ligação do Eu ao objeto de amor perdido, colocam em risco, em sua forma cindida, a autoconservação e a singularização do Eu ante o objeto.

Entretanto, o narcisismo que se encontra presente nas escolhas objetais não é característica exclusiva da afecção melancólica, estando sempre subjacente a qualquer escolha objetal. A substituição do narcisismo por um elevado ideal do Eu, como aponta Freud (1914a/2010), também não possibilita um arrefecimento do narcisismo, mesmo que coloque, tal como na melancolia, também o Eu numa relação de dependência absoluta ao objeto, que tanto pode ser colocado no lugar do ideal do Eu como no lugar do Eu.

Em ambos os casos, na idealização, que tem por base a substituição do narcisismo por um elevado ideal do Eu, e, na melancolia, em que se abdica do objeto, porém não do amor ao objeto para preservar o amor narcísico, tem-se uma intensificação do recalque. Se, no primeiro, preserva-se o objeto pelo viés da formação do ideal, tem-se que a renúncia é tão intensa que o Eu se empobrece e sucumbe ao objeto, renunciando ao amor, mas não ao narcisismo. No segundo, ao contrário, abdica-se do objeto, mas não se pode renunciar, em parte, ao amor narcísico. Não por acaso Freud (1917 a/2011) afirma que o enamoramento e o suicídio, em suas formas extremadas, expressam de formas distintas como pode o Eu tratar-se como um objeto.

Se ambos denunciam a atuação excessiva do recalque, também ali onde a melancolia apresenta-se como a impossibilidade de renúncia ao objeto sexual trata-se de um recalque na melancolia que cinde o Eu, para que o Eu não tenha de separar-se da libido narcísica. A 
complexidade é que o recalque restringe-se, desse modo, à pulsão agressiva que ao Eu retorna, aumentando a moralidade, mas não necessariamente a consciência.

De outro lado, a explícita renúncia ao objeto de amor que se evidencia na formação de um elevado ideal do Eu também não se torna suficiente para arrefecer o narcisismo, o que evidencia que, quando o recalque é excessivo, mesmo que se renuncie ao objeto de amor não necessariamente se renuncia a uma parte do amor narcísico.

Uma questão que se faz importante é que a impossibilidade de sublimar parte da libido retirada do objeto liga-se à rigidez do Supereu, de forma que o Eu, nessa relação, apresenta dificuldade em transitar entre o narcisismo e os investimentos objetais de forma menos destrutiva.

A relação entre o narcisismo e os investimentos objetais recolocam a questão presente desde o início da constituição do Eu entre o narcisismo e a identificação. O entrelaçamento entre dois tempos da experiência, o tempo vivido e o tempo significado, manifestam-se também no trabalho analítico sob a forma da transferência e ganham contorno a partir da repetição. A repetição coloca em cena o tempo vivido ao mesmo tempo em que expressa a tentativa de completar o que desse tempo não se realizou. Nessa dualidade, característica da organização dos processos psíquicos e dos investimentos libidinais, podem-se rastrear as pegadas de um tempo outro que não se desfez, mas que também não se realizou, deixando o sintoma, o sofrimento, o mal-estar e suas inibições como marcas no sujeito.

A impossibilidade de renunciar ao amor narcísico na melancolia parece advir da dificuldade do Eu de experienciar-se e representar-se como objeto de amor. Não encontrando em Eros a força que impulsiona à ligação do Eu ao amor (satisfação), o Eu divide-se para encontrar o amor na ligação ao objeto ausente. E, na defesa ao ódio, ele encontra a realidade. A realidade representa-se, sobretudo na melancolia, menos como a força de Eros que deriva do entrelaçamento, sempre conflituoso, entre o Eu e a realidade, mas, especialmente, como a 
defesa às pulsões agressivas, intensificadas em decorrência da impossibilidade de canalização para o mundo externo. Nesse sentido, Eros revela-se atuante. A divisão do Eu busca preservar tanto a satisfação quanto a realidade, ainda que, ao tornarem-se indistintos, Eros represente sobretudo a vida que faz morrer.

Portanto, a questão que se revela na melancolia coloca em cena a identificação a um objeto ausente de que resulta a formação de um rígido Supereu. Ainda que o Supereu torne-se a expressão da verdade inconsciente de uma forma de organização libidinal, ao transformar-se em representante interno da realidade acaba funcionando como meio de manutenção distorcida dessa verdade, na qual não se pode nem mesmo o Eu reconhecer-se.

No ensaio Delírios e Sonhos na Gradiva de Jensen, Freud (1907a/1974) aborda outra questão: sem referir-se à melancolia, apresenta uma compreensão importante sobre o delírio do personagem principal da obra, Hanold, ressaltando uma característica da engenhosidade do seu autor Ibsen. Trata-se da forma como Ibsen dispõe em palavras, através da personagem Zoe, uma "ambiguidade intencional" que caracteriza, de um lado, a extrema lucidez e clareza em oposição ao delírio do personagem principal e, de outro, a justeza das palavras ao delírio, dirigindo-o à compreensão consciente. Trata-se de uma forma criada pelo escritor que se resume em, através das palavras, fornecer ao delírio a tradução para a verdade inconsciente que ele representa. As palavras, nesse caso, ajustam-se ao delírio e o ultrapassam, de modo que a verdade inconsciente possa aparecer à consciência não como um erro consciente, mas como verdade.

A analogia que pode ser feita entre essa "ambiguidade intencional" abordada por Freud (1907a/1974) e o delírio das autoacusações do melancólico é pela negativa. O melancólico, por não sublimar parte da libido com a formação do Supereu e beneficiar-se da força do encontro com o outro, evidencia que, apesar de se formar um representante interno 
da realidade no $\mathrm{Eu}$, o Supereu não se torna expressão de uma verdade inconsciente ${ }^{9}$, ainda que se fortaleça a cada nova renúncia pulsional como um erro consciente ${ }^{10}$. O erro consciente manifesta-se na melancolia como consciência moral que, contraditoriamente, independe da consciência.

Quanto aos desdobramentos desse processo na melancolia, que envolve, sobretudo, o recalque em detrimento da sublimação, compreende-se que, apesar da excessiva consciência moral exercida pelo Supereu, contraditoriamente o Eu não adquire, em parte, o domínio sobre os impulsos do Id recalcados e tampouco sobre a consciência. A análise do delírio no melancólico, que se expressa em suas autorrecriminações exacerbadas, demonstra em grande parte a atuação inconsciente do Eu. Uma das características clínicas do delírio é a convicção inabalável que ele adquire. Essa convicção encontra-se presente no desprezo e nas autoacusações que o melancólico dirige a si mesmo, numa infindável autotortura.

Existe uma parcela de verdade oculta em todo delírio e essa parcela é responsável, até certo ponto, pela convicção do paciente em suas autoacusações (Freud, 1907a/1974). Todavia, esse elemento de verdade encontra-se recalcado e se (de forma distorcida) chega à consciência como um substituto moral para a verdade recalcada dá-se uma intensificação da convicção dessa verdade como forma de compensação que protege o substituto formado de qualquer crítica. "É como se a convicção se deslocasse da verdade inconsciente para o erro consciente que está ligado a ela, ali fixando-se justamente em consequência desse deslocamento" (Freud, 1907a/1974, p.83).

Essa fixação no erro inconsciente é mantida no melancólico através do investimento em seu complexo, que mantém a libido represada no Eu. Freud (1914a/2010) afirma que o fracasso da megalomania no parafrênico é o que induz tanto ao adoecimento quanto à tentativa de cura. Pode-se dizer que o fracasso do complexo melancólico também é o processo

\footnotetext{
${ }^{9}$ Referência à obra Delírios e Sonhos na Gradiva de Jensen (Freud, 1907a/1974, p.83).

${ }^{10}$ Delírios e Sonhos na Gradiva de Jensen (Freud,1907a/1974, p.83).
} 
que lança luz ao obscuro da melancolia. Entende-se que essa relação dúplice entre a patologia e a cura é possível porque encena o fracasso de uma ligação pulsional que sustenta o sujeito numa posição em que a verdade inconsciente se produz como erro consciente. A quebra de uma convicção é responsável tanto pela loucura como pelo processo de cura. Todavia, na melancolia, porque envolve um fracasso que remete ao originário da constituição do Eu, há um distanciamento menor entre a vida e a morte, deixando o sujeito mais propenso à angústia, mas também à criação.

Não obstante, precisamente pela relação a meio termo com a realidade que se representa pelo Supereu, a melancolia aproxima-se também da neurose de transferência. O Supereu, representando a defesa à realidade originária dos impulsos primitivos, revela em sua forma, mas não em seu conteúdo vazio de representação, a presença massiva da realidade em sua (não) mediação dos impulsos inconscientes. O Supereu revela, na melancolia, a intensidade e violência indomadas dos impulsos sexuais como também o aumento de sua potencialidade destrutiva quando o Eu não pode, conscientemente, apropriar-se, através da realidade, de sua verdade inconsciente.

A diferença é que, na neurose de transferência, o sujeito distancia-se da realidade, mas não desinveste eroticamente seus objetos. Nesse sentido, o conflito que se representa entre o Eu e o Id revela a contradição interna entre a realidade e o desejo. Na melancolia, o conflito entre o desejo e a realidade não pode ser representado internamente, sendo, portanto, suturado pela superposição da realidade psíquica em detrimento do mundo real. O fato é que o mundo real tornou-se presente no melancólico como algo vazio de representação e, por isso, tão presente como objeto sem contorno. Isto justificaria o recuo do melancólico do mundo real. Sem experienciar internamente o conflito de forma a dar-lhe vazão na vida real, ele transforma-se em objeto para construir internamente a realidade que não pôde, no mundo real, representar o conflito, tornando-se vazia. 
Roudinesco (1998) afirma que, para a psicanálise, a depressão é uma forma atenuada da melancolia que, nas sociedades industriais avançadas, se torna um equivalente da histeria. Entretanto, diferentemente da histeria que, segundo a autora, expressa-se como "uma revolta do corpo feminino contra a opressão patriarcal", a depressão aparece como a marca de um fracasso do paradigma da revolta "num mundo desprovido de ideais e dominado por uma poderosa tecnologia farmacológica” (p. 507).

O posicionamento de Roudinesco levanta uma questão quanto à diferença, no âmbito da cultura, entre a histeria e a depressão. A primeira seria a manifestação de uma revolta psíquica também no âmbito da cultura, que expressa o conflito entre as exigências de um corpo pulsional e as restrições excedentes de um modo de vida marcado pela opressão patriarcal. Na revolta da histeria, há a possibilidade de situar uma manifestação no sintoma histérico de um conflito entre o sujeito e a civilização e, no âmbito psíquico, o conflito entre o Eu e o objeto. Na depressão, Roudinesco (1998) se refere a um fracasso do paradigma da revolta que, de algum modo, remete ao amortecimento e à imobilidade de um conflito no sintoma, ainda que não à sua ausência.

No âmbito da clínica, Delouya (apud Fedida, 1999) faz uma análise a partir de uma característica essencial e paradoxal da depressão. O autor reflete sobre a imobilidade e o amortecimento depressivos. "A imobilidade e o amortecimento articulam-se, no sujeito, a uma violenta aflição, a um agito e excitação internas. Imagem que não é distante daquilo que entendemos por traumatismo ou reação traumática. Como se a imobilidade depressiva fosse a única medida defensiva a tomar perante uma violência indomável, uma ameaça de aniquilamento.” (Delouya, D. apud Fedida, 1999, p. 11).

De outro lado, no posfácio à nova edição de Luto e Melancolia, Peres (2011) considera o lugar ocupado na psicanálise por essa afecção psíquica. Ao abrir espaço para uma neurose narcisista, uma fronteira se abala, fazendo surgir uma inquietação. Em não permanecendo a 
melancolia na dualidade neurose-psicose, é inventada uma nova categoria que a retira, segundo Peres (2011), da dualidade empobrecedora.

A melancolia, expressão maior da nossa dor de existir, transporta um enigma, e temos de pensá-la em sua singularidade: nem simplesmente neurose, nem simplesmente psicose, ou seja, uma maneira de estar no mundo sem a reclusão do louco, sem o repúdio à realidade externa, como também sem a entrega e a submissão aos imperativos do Outro (Peres, 2011, p. 127).

Se essa característica da melancolia, por um lado, em sua forma limite, a coloca frente à patologia, diferenciando-a do luto, a aproxima também da característica de busca a um ideal que se esquiva, encontrada também nos processos de criação e nos sujeitos não melancólicos. A impossibilidade permanente do luto, expressão distintiva da melancolia quanto às outras formas de afecções psíquicas, é também, paradoxalmente, algo que se liga à natureza da condição do objeto e do sujeito na psicanálise e, portanto, constitui-se em ponto de partida. $\mathrm{O}$ "trabalho de luto" nunca é permanente no sentido de algo que é estagnado, característica que tem a ver, ela mesma, com o que se encontra no limite entre o luto e a melancolia. Se a melancolia revela-se como a impossibilidade permanente de um trabalho de luto, este, a seu modo, revela-se como possibilidade incerta, sem ponto de chegada.

A aproximação e o distanciamento entre a melancolia e a depressão, a partir de alguns autores, não tem por finalidade sintetizá-las, mas ressaltar que a relação entre o Eu e o objeto que se evidencia em sua forma limite e patológica na melancolia aponta a tênue relação entre o sujeito e a realidade e, portanto, entre a sexualidade e a cultura. A forte defesa à pulsão agressiva exercida pela consciência moral no melancólico é expressão de uma defesa exacerbada à sexualidade que não pôde ser representada e experienciada internamente.

Assim, a realidade representa-se, no melancólico, como ausência da qual ele se defende com a adesão inconsciente à realidade sob a forma da moralidade. A melancolia 
deixa abertas, pelo desvendamento da relação entre o Eu e o objeto, indagações fundamentais da relação entre o sujeito e a cultura. No âmbito da clínica, especificamente, sugere inevitáveis questões quanto à compreensão da técnica psicanalítica no manejo do tênue limiar entre a vida e a morte, entre a euforia da fase maníaca e o imobilismo do melancólico e, por fim, entre o Eu e o Supereu.

Fedida (2003), partindo da compreensão do tempo que não se inscreveu no melancólico, também levanta algumas reflexões clínicas que possibilitam pensar a natureza da melancolia como afecção que coloca em cena esse tênue limiar. Questiona-se sobre qual seria a importância da transferência na análise do melancólico enquanto possibilidade de inscrição de um tempo em outro tempo que não se constituiu como acontecimento psíquico. Seria a transferência momento privilegiado através do qual o analista poderia propiciar uma reconstrução de um acontecimento psíquico não vivido pelo melancólico, porém nele excessivo, e, portanto, tempo de possibilidade de reconstrução de uma metáfora do vazio?

Contrapondo-se à Winnicot (apud Fedida, 1999, p. 91) em seu texto Medo do Desmoronamento, ele critica determinadas formas de concepção da técnica cuja exigência ocorre em detrimento da concepção do que seja o negativo na análise. A partir desta crítica, ele constrói elementos fundamentais para que se possa compreender o trauma em psicanálise: não é positivando o acontecimento traumático em análise que se pode reconstruir a falta ou a perda ali onde se produziram. A crítica de Fedida a Winnicott respalda-se nessa questão. Para Winnicott, "o medo do desmoronamento pode ser o medo de um acontecimento passado cuja experiência ainda não foi vivida. A necessidade de viver essa experiência é equivalente ao que pode ser a necessidade de rememorar na análise dos psiconeuróticos" (Winnicott apud Fedida, 1999, p. 91).

Para Fedida (1999), conferir um conteúdo ao desmoronamento ou ao vazio na transferência representa uma aposta do analista na possibilidade de representação do 
traumatismo, localizando-o numa determinada zona psíquica e remetendo-o a um passado longínquo. Todavia, isso gera um impasse terapêutico já que, segundo ele, a metáfora, a partir do trauma, "é a capacidade da criação exatamente na angústia de destruição - desde que a escuta do analista não busque o conteúdo recalcado" (p.92). Em certo sentido, cabe ao analista suportar em sua escuta "a insistência repetitiva da ameaça em instância, como que suspensa em sua iminência” (p.92). Só dessa forma irá escutar o que já-teve-lugar-nunca-em-lugarnenhum" (Fedida, 1999, p.92).

A ideia de que se possa escutar na transferência o que "já teve lugar nunca em lugar nenhum" desvela a condição de que a ameaça de desmoronamento, no que se refere à perda, não pode ser reconstruída, na análise, por meio da positivação do negativo. A transferência indica que se trata de uma ausência presente enquanto angústia, excitação e agitação internas, constituída originariamente por um modo de identificação que não pode ser refeito na análise simplesmente atribuindo ao que é da ordem do negativo na transferência um lugar que não se constituiu psiquicamente. Esse parece ser o impasse da análise relativamente à melancolia.

A compreensão da mania, contraface da melancolia, de outro lado, coloca em evidência outra cena do mesmo complexo, também importante para pensar a clínica. Trata-se da liberação de uma energia narcísica que se torna disponível para outros investimentos quando o Eu encontra-se temporariamente livre do Supereu. Não se sabe, segundo Freud (1917a/2011), a origem dessa fusão temporária entre o Eu e o Supereu e tampouco o que a torna possível. De qualquer modo, é um período que demonstra que o Eu, por longa data oprimido pelo Supereu, busca, na fase maníaca, um triunfo sobre ele. A liberação da libido narcísica investida no complexo melancólico deixaria o sujeito mais propenso a novos investimentos. Nessa direção, Khel (2011) se coloca uma questão.

$\mathrm{Na}$ clínica da melancolia, será o sujeito capaz de intentar novos destinos pulsionais para não reduzir a mania a um período de investimentos cegos, loucos? Será o melancólico de nossa clínica 
cotidiana capaz de sublimar uma parte do "estado violento do desejo" que se apodera dele no ciclo maníaco? Seremos nós, analistas, capazes de escutar as intensas expressões de alívio daquele que se vê provisoriamente liberado da batalha inconsciente em torno do objeto amado/odiado, de modo a permitir que ele dê à sua excitação algum destino que construa outro sentido para a sua falta a ser? (Khel, 2011, p. 30).

A mania na análise freudiana é importante por significar um desinvestimento do complexo melancólico e, portanto, uma liberação de libido narcísica. Tendo o Supereu temporariamente se fundido ao Eu, as autoacusações e delírios de inferioridade deixariam, temporariamente, de estar mobilizados, podendo derivar dessa suspensão outras formas de investimentos até então impedidas pela força do Supereu. No entanto, sabe-se que o triunfo do Eu sobre o Supereu não significa imediatamente a possibilidade de desvincular-se da sombra do objeto perdido, embora represente o desligamento temporário da libido de uma determinada forma de satisfação sexual até então envolvida na manutenção do complexo melancólico.

A melancolia e a mania representam em suas diferenças a proximidade quase indistinta entre a euforia e o imobilismo, a morte e a vida, o triunfo e a submissão. Em comum entre ambos, tem-se o desconhecimento do Eu sobre o objeto perdido que o submete e sobre o qual triunfa e, portanto, a sombra do objeto que envolve o melancólico. O imobilismo do melancólico e a euforia da fase maníaca representam, no campo psicanalítico, os efeitos psíquicos dos impasses da constituição interna de um outro, que faz frente ao sujeito e o interpela, mesmo quando se impõe como ausência.

O intuito de Freud de manter o estudo da melancolia num campo que não fosse nem estritamente o da neurose nem se enquadrasse na psicose parece dizer de uma necessidade de se compreender a melancolia no lugar em que ela se revela. O tênue limite do melancólico retrata a tensão entre a vida e a morte, entre o riso e a dor, entre a criação e o adoecimento. No entanto, revela, de outro lado, que a indeterminação no Eu quanto a esses limites inviabiliza 
que o sujeito possa experienciar internamente a experiência de vida e morte, de forma a atribuir-lhe uma significação.

A indeterminação entre esses limites cobra seu preço. A indistinção entre o Eu e o objeto, se acena com a promessa de uma falsa totalidade, também inviabiliza a suspensão do desejo que caracteriza a possibilidade de tornar-se outro. Se a indeterminação torna o melancólico propenso a habitar extremos, aproximando-o da angústia e da criação, já não pode distinguir entre o prazer e a dor em seu limite. Insistir no termo melancolia, tal como Freud o fez, é uma forma de não ceder à indeterminação e não abdicar da tensão que, quando não se representa como desejo, se apresenta como pulsão de morte. A melancolia também se encontra, para Freud, em um entredois que não pode ser desfeito sob o risco de aproximar-se dos extremos, sem que se possa compreendê-los ou tampouco experienciá-los. 


\section{REFERÊNCIAS}

DELOUYA, Daniel. Depressão, metáfora primitiva da psique. In: FEDIDA P. Depressão. Tradução de Martha Gambini. São Paulo: Editora Escuta, 1999.

FEDIDA, Pierre. Depressão. Tradução de Martha Gambini. São Paulo: Editora Escuta, 1999.

FREUD, S. Três Ensaios sobre a Teoria da Sexualidade (1905a/1974). Edição Standard Brasileira das Obras Completas. v. VII. Rio de Janeiro: Imago, 1974.

FREUD, S. Delírios e Sonhos na Gradiva de Jensen (1907a/1974). Edição Standard Brasileira das Obras Completas. v. IX. Rio de Janeiro: Imago, 1974.

FREUD, S. Totem e Tabu (1913a/1974). Edição Standard Brasileira das Obras Completas. v. XIII. Rio de Janeiro: Imago, 1974.

FREUD, S. Introdução ao Narcisismo: ensaios de metapsicologia e outros textos (19141916). (1914 a/2010). Tradução e notas de Paulo César de Souza. São Paulo: Companhia das Letras, 2010.

FREUD, S. As pulsões e seus destinos (1915 a/2013). Tradução de Pedro Heliodoro Tavares. Belo Horizonte: Autêntica Editora, 2013.

FREUD, S. A Repressão (1915b/2010). Introdução ao narcisismo: ensaios de metapsicologia e outros textos (1914-1916). Tradução e notas de Paulo César de Souza. São Paulo: Companhia das Letras, 2010.

FREUD, S. Alguns tipos de caráter encontrados na prática psicanalítica (1916b/2010). Introdução ao narcisismo: ensaios de metapsicologia e outros textos (1914-1916). Tradução e notas de Paulo César de Souza. São Paulo: Companhia das Letras, 2010.

FREUD, S. A Transitoriedade (1916a/2010). Introdução ao narcisismo: ensaios de metapsicologia e outros textos (1914-1916). Tradução e notas de Paulo César de Souza. São Paulo: Companhia das Letras, 2010.

FREUD, S. Luto e melancolia (1917a/2011). Tradução, introdução e notas de Marilene Carone. São Paulo: Cosac Naify, 2011.

FREUD, S. Além do Princípio do Prazer (1920a/1974). Edição Standard Brasileira das Obras Completas. v. XVIII. Rio de Janeiro: Imago, 1974.

FREUD, S. Psicologia de Grupo e a Análise do Ego (1921a/1974). Edição Standard Brasileira das Obras Completas. v. XVIII. Rio de Janeiro: Imago, 1974.

FREUD, S. O Eu e o Id: autobiografia e outros textos (1923a/2011). Tradução e notas de Paulo César de Souza. São Paulo: Companhia das Letras, 2011. 
FREUD, S. A Dissolução do complexo de Édipo (1924c/2011). O eu e o id: autobiografia e outros textos (1923-1925). Tradução e notas de Paulo César de Souza. São Paulo: Companhia das Letras, 2011.

FREUD, S. A perda da realidade na neurose e na psicose $(1924 \mathrm{~d} / 2011)$ O eu e o id: autobiografia e outros textos (1923-1925). Tradução e notas de Paulo César de Souza. São Paulo: Companhia das Letras, 2011.

FREUD, S. Neurose e Psicose (1924a/2011). O eu e o id: autobiografia e outros textos (19231925). Tradução e notas de Paulo César de Souza. São Paulo: Companhia das Letras, 2011.

FREUD, S. O Problema Econômico do Masoquismo (1924b/2011). O eu e o id: autobiografia e outros textos (1923-1925). Tradução e notas de Paulo César de Souza. São Paulo: Companhia das Letras, 2011.

FREUD, S. Novas conferências introdutórias sobre psicanálise (1933a/1974). Edição Standard Brasileira das Obras Completas. v. XXII. Rio de Janeiro: Imago, 1974.

FREUD, S. O Mal-estar na civilização (1930a/1974). Edição Standard Brasileira das Obras Completas. v. XXI. Rio de Janeiro: Imago, 1974.

FREUD, S. Esboço de Psicanálise (1938a/1974). Edição Standard Brasileira das Obras Completas. v. XXIII. Rio de Janeiro: Imago, 1974.

KEHL, Maria Rita. O tempo e o cão: a atualidade das depressões. São Paulo: Boitempo, 2009.

KEHL, Maria. Rita. Melancolia e Criação (2011). Luto e Melancolia. Tradução, introdução e notas de Marilene Carone. São Paulo: Cosac Naify, 2011.

MENEZES, Aluizio. Sublimação e Escrita. In: Clínica Psicanalítica. n. 3, Colégio Freudiano do Rio de Janeiro, 1988.

PERES, Urania, Tourinho. Uma ferida a sangrar-lhe a alma (2011). Luto e Melancolia. Tradução, introdução e notas de Marilene Carone. São Paulo: Cosac Naify, 2011.

PONTALIS, J-B. Este Tiempo que no Pasa. 1 ed. Buenos Aires: Topía Editorial, 2005.

ROUDINESCO, E.; PLON, M. Dicionário de Psicanálise. Rio de Janeiro: Jorge Zahar Ed., 1998.

SOARES, Renata Leite (2005). Cultura e Repressão: entre a universalidade, a singularidade e as possibilidades da condição humana. Dissertação de mestrado nãopublicada, Universidade Federal de Goiás, Goiânia, Brasil. 